\title{
Testing and Data Recovery Excavations at 41BU51, Burleson County, Texas
}

Cory J. Broehm

Jennifer K. McWilliams

Texas Historical Commission

Ross C. Fields

Karl W. Kibler

Cross Timbers Geoarcheological Services

Follow this and additional works at: https://scholarworks.sfasu.edu/ita

Part of the American Material Culture Commons, Archaeological Anthropology Commons, Environmental Studies Commons, Other American Studies Commons, Other Arts and Humanities Commons, Other History of Art, Architecture, and Archaeology Commons, and the United States History Commons

Tell us how this article helped you.

This Article is brought to you for free and open access by the Center for Regional Heritage Research at SFA ScholarWorks. It has been accepted for inclusion in Index of Texas Archaeology: Open Access Gray Literature from the Lone Star State by an authorized editor of SFA ScholarWorks. For more information, please contact cdsscholarworks@sfasu.edu. 


\section{Testing and Data Recovery Excavations at 41BU51, Burleson County, Texas}

\section{Licensing Statement}

This is a work for hire produced for the Texas Department of Transportation (TxDOT), which owns all rights, title, and interest in and to all data and other information developed for this project under its contract with the report producer. The report may be cited and brief passages from this publication may be reproduced without permission provided that credit is given to TXDOT and the firm that produced it. Permission to reprint an entire chapter, section, figures or tables must be obtained in advance from the Supervisor of the Archeological Studies Branch, Environmental Affairs Division, Texas Department of Transportation, 125 East 11th Street, Austin, Texas, 78701. 


\title{
TESTING AND DATA RECOVERY EXCAVATIONS AT 41BU51, BURLESON COUNTY, TEXAS
}

\author{
by \\ Cory J. Broehm \\ Jennifer K. McWilliams \\ Ross C. Fields \\ and
}

Karl W. Kibler

Principal Investigator: Ross C. Fields
REPORTS OF INVESTIGATIONS, NUMBER 161
Prewitt and Associates, Inc.
Cultural Resources Services
Austin, Texas

\begin{abstract}
ARCHEOLOGICAL STUDIES PROGRAM, REPORT NO. 124
Texas Department of Transportation

Environmental Affairs Division

Archeological Studies Program
\end{abstract}

CSJ No. 0648-03-046

June 2010

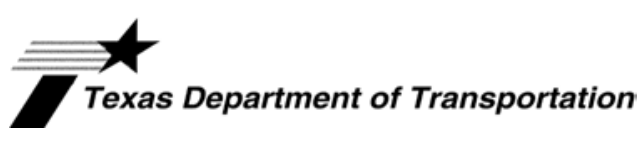

TEXAS ANTIQUITIES PERMIT NOS. 3030 and 4546

PAI Nos. 202033, 203028, 203046, and 207029 


\title{
TESTING AND DATA RECOVERY EXCAVATIONS AT 41BU51, BURLESON COUNTY, TEXAS
}

\author{
COPYRIGHT @ 2010
}

Texas Department of Transportation (TxDOT)

This is a work for hire produced by the Texas Department of Transportation (TxDOT), which owns all rights, title, and interest in and to all data and other information developed for this project under Contract No. 573XXSA001 (Work Authorizations 57301SA001, 57308SA001, and 57312SA001) and Contract No. 577XXSA001 (Work Authorization 57715SA001). Brief passages

from this publication may be reproduced without permission provided that credit is given to TxDOT and Prewitt and Associates, Inc. Permission to reprint an entire chapter, section, figures, or tables must be obtained in advance from the Supervisor of the Archeological Studies Program,

Environmental Affairs Division, Texas Department of Transportation, 125 East 11th Street, Austin, Texas, 78701. Copies of this publication have been deposited with the Texas State Library in compliance with the State Depository Requirement.

\author{
jointly published by the \\ Texas Department of Transportation \\ Environmental Affairs Division \\ Archeological Studies Program \\ Scott Pletka, Ph.D., Supervisor, Archeological Studies Program \\ Archeological Studies Program, Report No. 124 \\ $\mathrm{Al}$ McGraw, Series Editor \\ and \\ Prewitt and Associates, Inc. \\ Cultural Resources Services \\ Austin, Texas \\ PAI Project Nos. 202033, 203028, 203046, and 207029
}

Reports of Investigations, Number 161

Printed by Morgan Printing in Austin, Texas

ISBN 1-930788-93-2 


\section{TABLE OF CONTENTS}

ABSTRACT

vii

ACKNOWLEDGMENTS

viii

CHAPTER 1: INTRODUCTION AND BACKGROUND INFORMATION …............................. 1

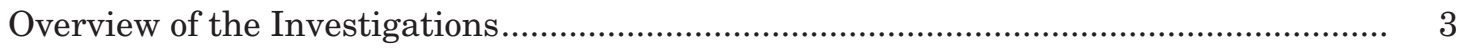

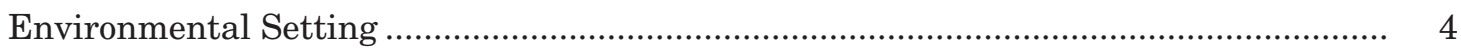

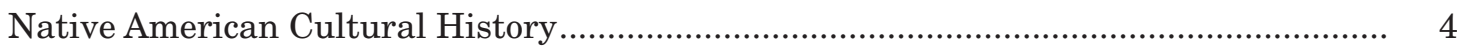

Paleoindian Period (10,000-6500 B.C.)........................................................... 5

Archaic Period (6,500 B.C.-A.D. 700) ............................................................. 5

Late Prehistoric Period (A.D. 700-1680) ...................................................... 9

Historic Period (A.D. 1680-1750) ............................................................. 12

CHAPTER 2: WORK ACCOMPLISHED AND SUMMARY OF RESULTS.............................. 13

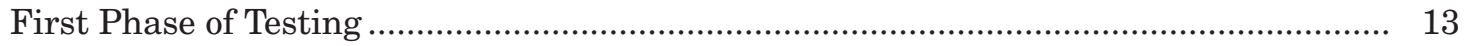

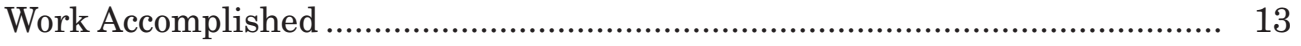

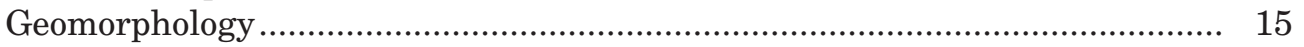

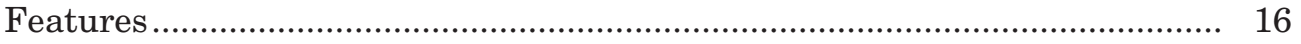

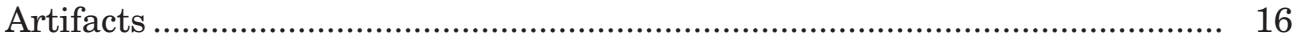

Initial Site Assessment .......................................................................... 17

Need for a Second Phase of Testing............................................................. 17

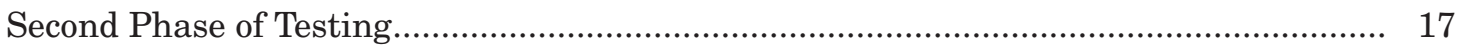

Work Accomplished ............................................................................ 17

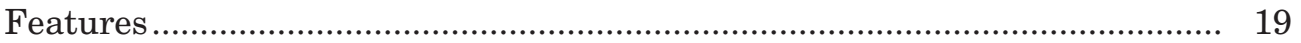

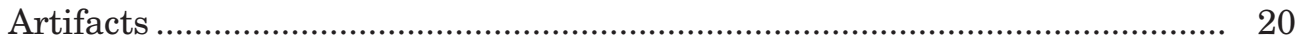

Revised Site Assessment................................................................ 20

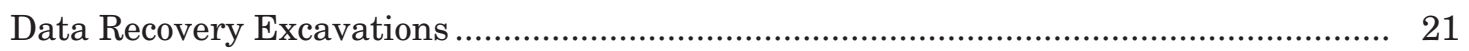

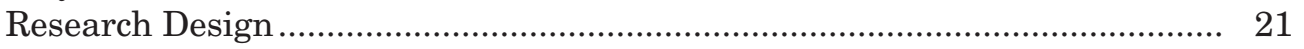

Work Accomplished ........................................................................... 22

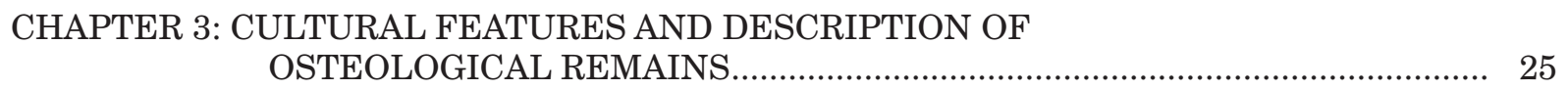

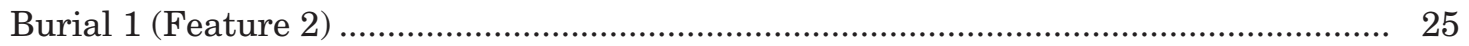

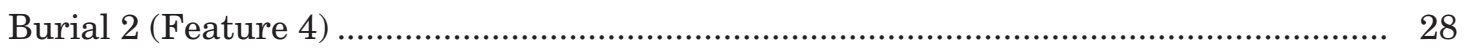

Burial 3 (Feature 5) ............................................................................................... 30

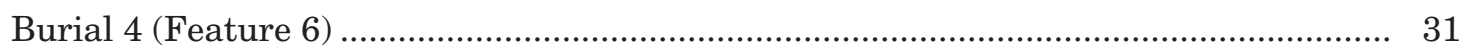

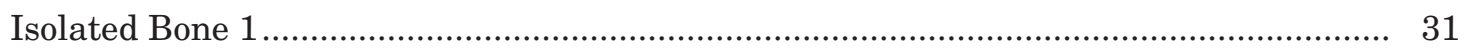

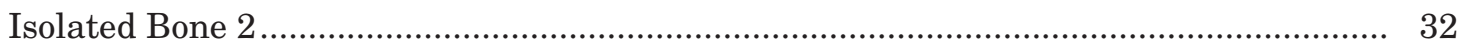

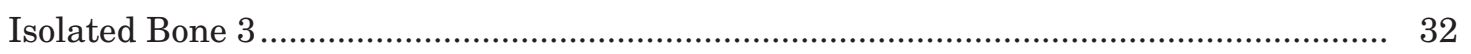

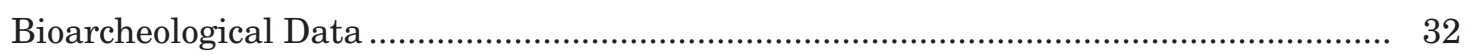

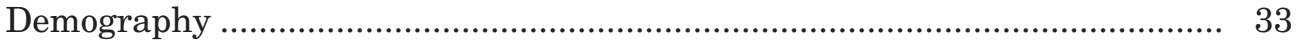

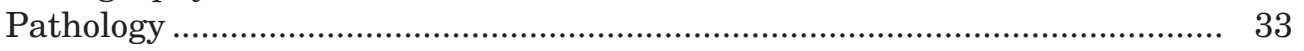




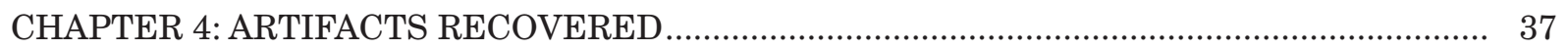

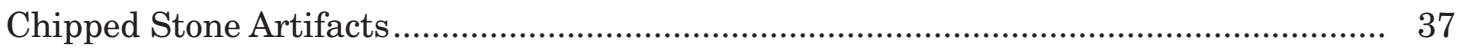

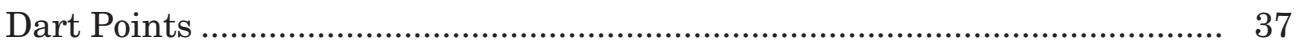

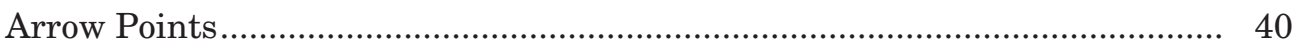

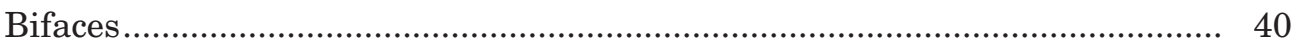

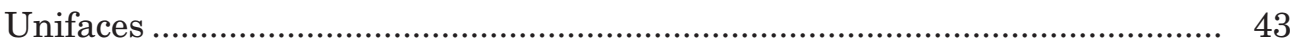

Edge-Modified Flakes.............................................................................. 43

Cores and Tested Cobbles ........................................................................... 46

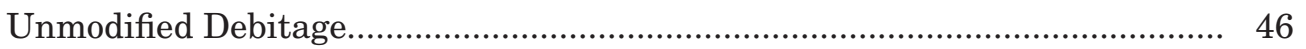

Ground, Battered, and Striated Stones ................................................................. 46

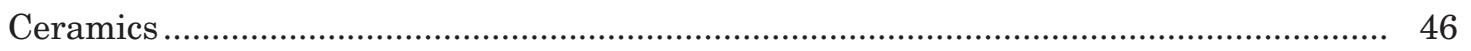

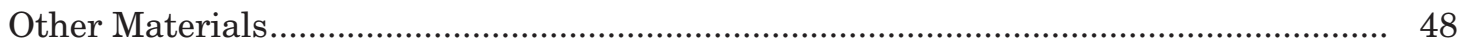

Burned Rocks................................................................................................. 48

Possibly Flaked Silicified Wood .................................................................... 48

Burned Clay ........................................................................................... 49

Vertebrate and Invertebrate Faunal Remains .......................................... 49

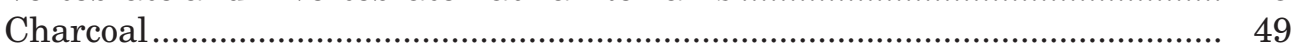

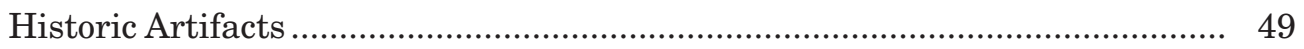

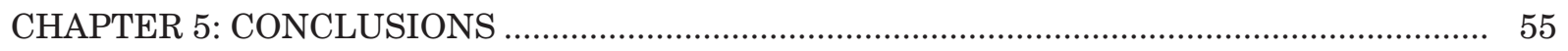

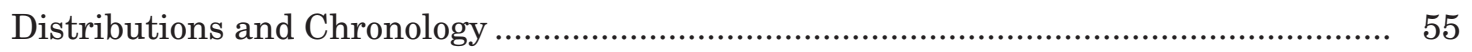

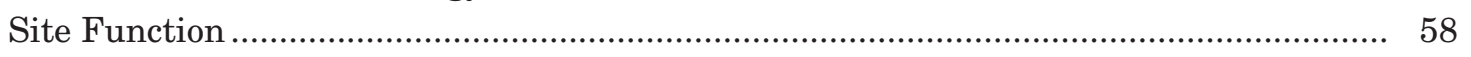

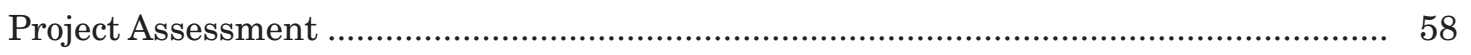

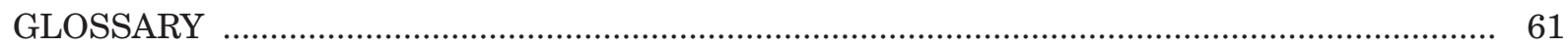

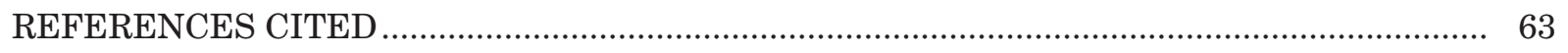

APPENDIX A: Selected Backhoe Trench Profiles ................................................................... 69

APPENDIX B: Skeletal Diagrams Showing Sided Elements

Represented in Burials 1-4 ...................................................................... 73 


\section{LIST OF FIGURES}

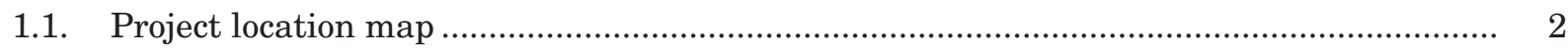

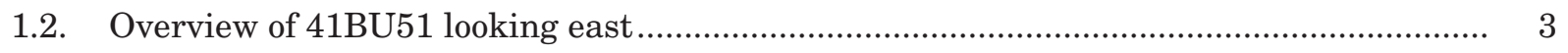

2.1. Map showing excavations in the first phase of testing................................................... 14

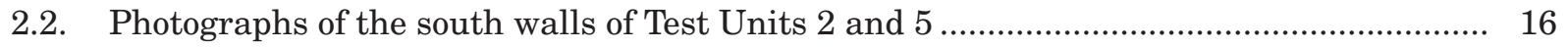

2.3. Plan of area excavated in the second phase of testing, showing locations of Burials 1-4 and Isolated Bones 1-3 ........................................................................... 19

2.4. Photograph of Gradall excavation in progress ................................................................ 20

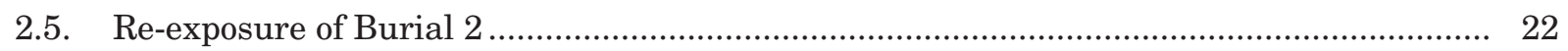

3.1. Plan showing the locations of Burials 1-4 and Isolated Bones 1 and 2 ......................... 26

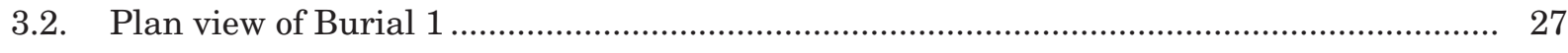

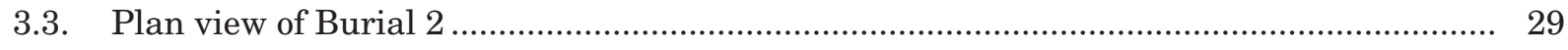

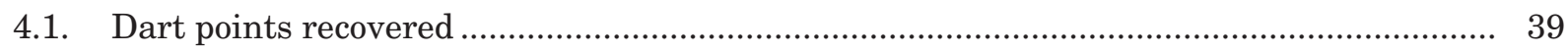

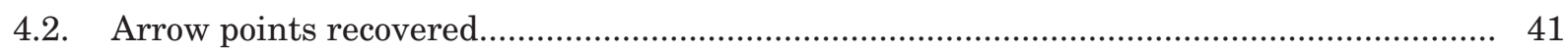

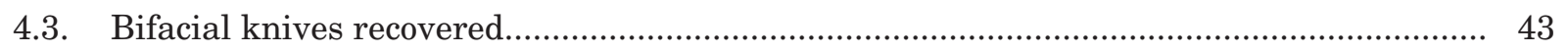

4.4. Ground sandstone abrader and striated ocher ........................................................... 48

4.5. Prehistoric ceramic sherds ............................................................................................ 50

4.6. Burned clay with impressions........................................................................................ 50

5.1. Graphs showing vertical distributions of lithic artifacts, burned rocks, and burned clay in Test Units 2 and 5-12. 


\section{LIST OF TABLES}

4.1. Provenience and metric data for dart points.................................................................. 38

4.2. Provenience and metric data for arrow points ................................................................. 41

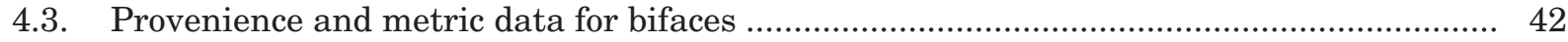

4.4. Provenience, metric, and raw material data for edge-modified flakes .............................. 44

4.5. Provenience and metric data for cores and tested cobbles .............................................. 47

4.6. Unmodified debitage characteristics ......................................................................... 48

4.7. Provenience and metric data for ground, battered, and striated stones ......................... 49

4.8. Provenience data for other materials and unmodified debitage ...................................... 51

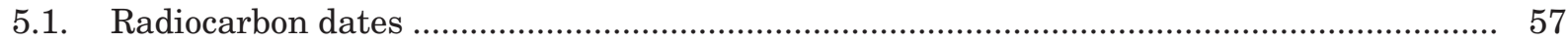




\begin{abstract}
Prewitt and Associates, Inc. (PAI), conducted archeological testing and data recovery excavations at prehistoric site 41BU51 in Burleson County, Texas, for the Texas Department of Transportation, Environmental Affairs Division, in three phases of investigation. The first phase of testing, conducted in Spring 2003, resulted in the discovery of a single human burial as well as diagnostic artifacts ranging from the Archaic period through the Late Prehistoric period. A second phase of testing was conducted to search for additional burials in January 2004. This work resulted in the discovery of three additional burials and two isolated human bones. Finally, data recovery to remove the human remains was conducted in June 2007. This report describes all three phases of work.

Analysis of the data recovered indicates that 41BU51 has a Late Archaic component that contributed many or even most of the lithic artifacts, most of the burned rocks and burned clay, some or all of the ceramic artifacts, and probably all of the human burials. Materials representing Late Prehistoric period occupations also are present, and the possibility exists that large numbers of the lithic artifacts in the upper $60 \mathrm{~cm}$ of the deposits were left by these occupations. A small number of artifacts predating the Late Archaic period were recovered, but these are older items recycled into younger deposits. Radiocarbon dates indicate that the Late Archaic and Late Prehistoric use of the site occurred over perhaps 3,200 to 3,600 years. The vertical distributions of the temporally sensitive artifacts and the radiocarbon dates, while hinting at some remnant time-related stratification of the cultural materials, make it clear that there has been much mixing of the deposits, presumably through faunal turbation and other forms of disturbance. With this degree of mixing, it is impossible to segregate the remains by time period or more-discrete components. Nonetheless, the archeological remains recovered indicate that 41BU51 was used intermittently over a long span of time, probably as a residential campsite, with some occupations during the Late Archaic period perhaps being for extended periods of time.
\end{abstract}




\section{ACKNOWLEDGMENTS}

Numerous people participated in this project over its seven-year duration. TxDOT personnel who oversaw the project included Cindy Tennis, Mary Jo Galindo, and Jason Barrett. Jason's efforts to bring the analysis and reporting of the data to completion are especially appreciated. The landowner at the time of the test excavations, Earl Sebesta, was friendly and accommodating throughout the fieldwork.

Ross C. Fields served as principal investigator and Jennifer McWilliams as project archeologist throughout the investigations. Cory Broehm was co-project archeologist during the second phase of testing and the data recovery excavations. Rob Thrift operated the Total Data Station for all phases and served as archeological technician during data recovery. Other archeological technicians for data recovery were Roman Clem and Mark Holderby. Archeological technicians for the first phase of testing were Rachel Davies, Weldon Hammond, and Greg LaBudde. Cory Broehm and Cindy Tennis served as in-field osteologists for the second phase of testing, and Mr. Broehm performed the osetological analysis. Mr. Broehm, Ms. McWilliams, Mr. Fields, and Karl W. Kibler wrote the report. Ms. McWilliams conducted lithic analysis with the help and support of John Dockall. Mr. Kibler wrote the section on the soils and stratigraphy of the site. Sandy Hannum and Brian Wootan produced the graphics, and Elaine Robbins and Ross Fields edited the report. 


\section{INTRODUCTION AND BACKGROUND INFORMATION}

This report describes two phases of test excavations and data recovery excavations preformed by Prewitt and Associates, Inc., at prehistoric site 41BU51. The work was done for the Texas Department of Transportation, Environmental Affairs Division (TxDOT-ENV), under Contract No. 573XXSA001 (Work Authorizations 57301SA001, 57308SA001, and 57312SA001) and Contract No. 577XXSA001 (Work Authorization 57715SA001) to address the requirements of Section 106 of the National Historic Preservation Act and the Texas Antiquities Code. TxDOT's planned widening of FM 60, which will affect the archeological deposits at 41BU51, prompted the work described here.

Site 41BU51 is in eastern Burleson County, Texas, just north of the town of Snook. The site lies at a maximum elevation of $240 \mathrm{ft}$ above sea level on a sandy ridge on the western wall of the Brazos River valley (Figure 1.1). The ridge is an open pasture that is traversed by a two-track road running eastward from the highway to a residence. For a distance of ca. $100 \mathrm{~m}$ from the edge of the existing right of way, this road is in a large borrow pit (30-35 m wide) that has been cut as much as $2 \mathrm{~m}$ below the natural surface (Figure 1.2). As described in this report, 41BU51 is a multicomponent prehistoric site encased in late Holocene colluvium and slopewash.

Site 41BU51 was first recorded in the 1970s by William Moore of Brazos Valley Research Associates, based on the presence of lithic debitage and an arrow point found on the surface of the FM 60 road cut south of Old River. He estimated that the site could cover an area of ca. 200x400 m, but he apparently did not have access to land outside the highway right of way and thus was not able to walk over the site. Shovel testing was recommended to determine the site's eligibility for National Register listing and State
Archeological Landmark designation.

The first substantive work was done in 2002, when personnel from Prewitt and Associates revisited the site while conducting a survey of FM 60 for the Texas Department of Transportation (McLoughlin 2002). They conducted a pedestrian survey of the ca. 62 -m-wide proposed new right of way east of FM 60 and excavated a series of backhoe trenches. Lithic debitage was observed eroding from thin (ca. 20-25 cm) sands atop hard red clay on the south side of the borrow pit; because of the shallow nature of the deposits in this area of the site, no excavations were performed. Trench 3 was dug ca. $50 \mathrm{~m}$ south of the borrow pit on a gradual, south-facing slope and exposed ca. $60 \mathrm{~cm}$ of sand above red clay. Just above the contact with the clay, 2 flakes and 1 burned rock were observed; hence, this area was included as part of $41 \mathrm{BU} 51$. A trench ca. $100 \mathrm{~m}$ farther south was negative and was not included within the boundaries of 41BU51. Trench 2 was on the ridgetop north of the borrow pit. This trench was excavated to ca. $150 \mathrm{~cm}$ and encountered hard red clay below tan sand. While inspecting the trench walls, numerous flakes $(n=20), 1$ pebble core, 2 burned rocks, and 1 Godley-like dart point were recovered. All of the artifacts came from between 140 and $150 \mathrm{~cm}$ below the surface, within the tan sand layer on top of the red clay. Trench 1 , ca. $50 \mathrm{~m}$ north of Trench 2 on the Old River floodplain, was dug to $162 \mathrm{~cm}$ and exposed Holocene alluvial deposits; it did not contain any archeological materials.

Based on the artifacts observed in Trenches 2 and 3 , the cultural deposit at 41BU51 appeared to be fairly discrete and limited to the Holocene sands $10 \mathrm{~cm}$ above the Eocene red clay. Further testing was recommended to assess the site more fully. 

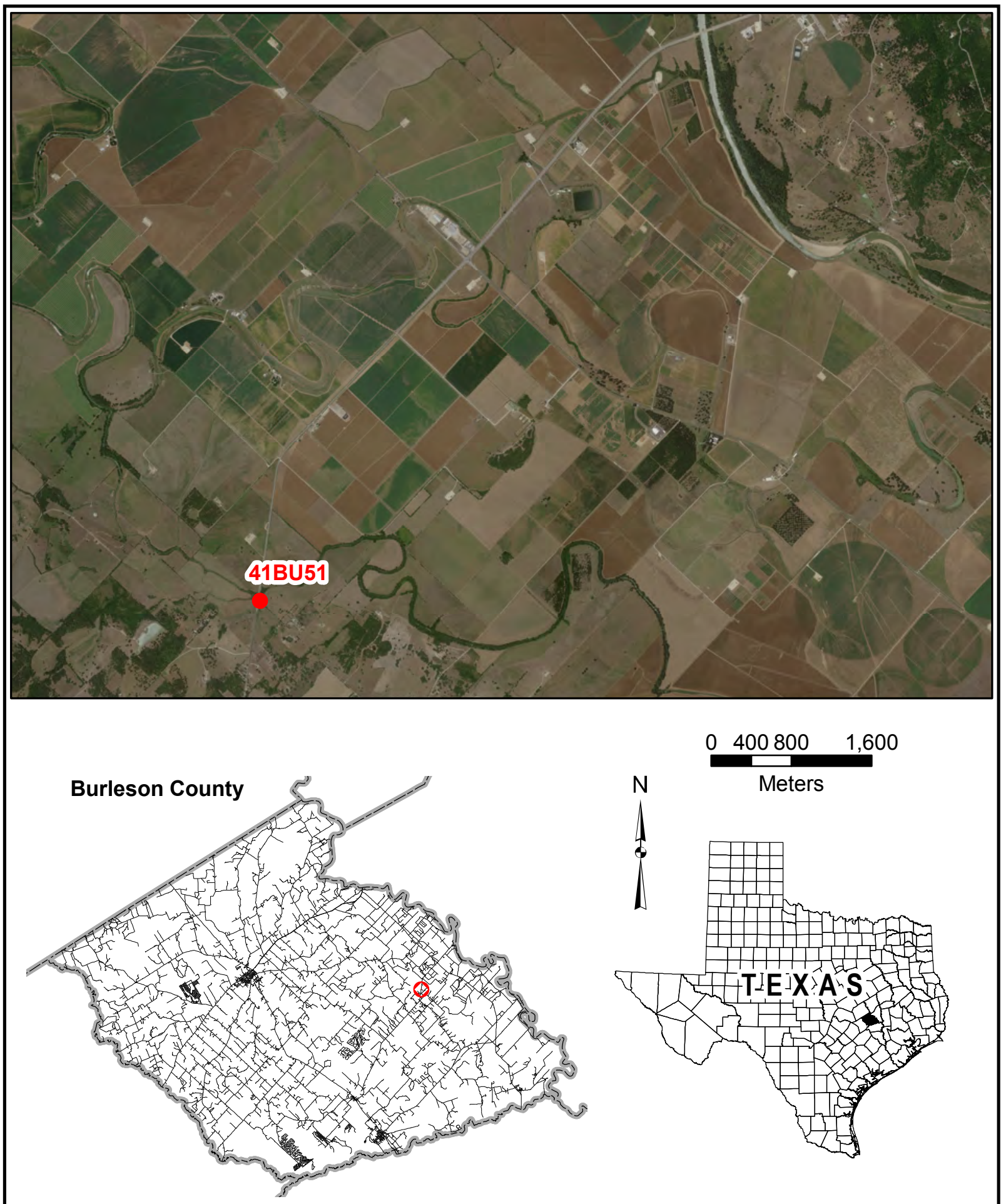

PAl/10/slh

Figure 1.1. Project location map. 


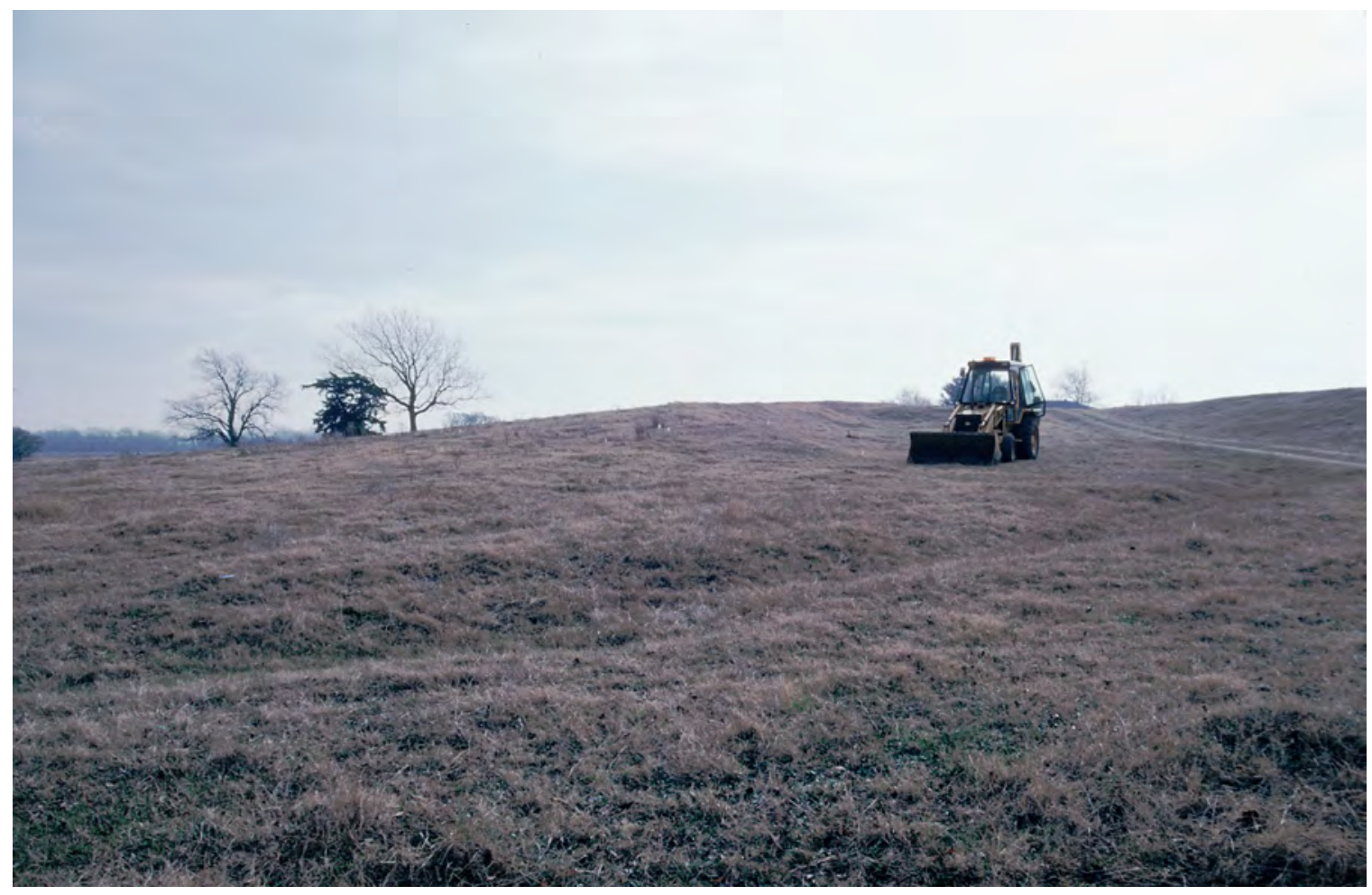

Figure 1.2. Overview of 41BU51 looking east; the backhoe and two-track road to the right are in the large borrow pit that cuts through the site.

\section{OVERVIEW OF THE INVESTIGATIONS}

The work reported here consists of both test excavations carried out as a follow-up to the 2002 survey efforts to evaluate the site's National Register and State Archeological Landmark eligibility, and subsequent data recovery excavations intended to mitigate the loss of the site to planned road widening. The testing was conducted in two phases. During the first, which took place in February and March 2003, $15.4 \mathrm{~m}^{3}$ of sediments were excavated in twelve $1 \times 1-m$ units, two-thirds of which were arranged in a single block. One cultural feature-a cluster of bones-and a large number of artifacts were recovered. Temporally diagnostic artifacts suggested that the site was used during the Archaic, particularly Late Archaic, and Late Prehistoric periods. However, the site lacked discrete components and showed extensive disturbance and hence was deemed ineligible for listing in the National Register of Historic Places and designation as a State Archeological Landmark.

Subsequent laboratory analysis of the bones from the feature revealed they were part of a human burial, however, and thus a second phase of testing was considered necessary to address the possibility of additional human remains at the site and to potentially reevaluate the site's eligibility. This work, performed in January 2004, revealed three additional burials and three isolated bones, two of probable human origin, in a ca. $20 \times 16-\mathrm{m}\left(333-\mathrm{m}^{2}\right)$ excavated area centered on the location of the first burial. These skeletal remains were left in situ after they were positively identified as human.

Based on these findings, the site was deemed eligible for listing in the National Register of Historic Places under Criterion D and for designation as a State Archeological Landmark, and a data recovery plan was prepared. The fieldwork portion of this plan, which consisted of removal of the three burials and the isolated bones, took place in June 2007.

This report consists of five chapters. This chapter describes the environmental setting of the project area and provides archeological background information. Chapter 2 describes the work accomplished in the three phases of study. Chapter 3 describes and discusses the human remains, and Chapter 4 describes the 
artifacts and other nonosteological remains recovered. Chapter 5 offers conclusions about the chronology and function of 41BU51. Appendix A contains descriptions of the soil stratigraphy of selected backhoe trench profiles. Appendix B contains diagrams showing the sided elements represented in Burials 1-4.

\section{ENVIRONMENTAL SETTING}

Site $41 B U 51$ sits on a ridge about $4-5 \mathrm{~m}$ above the valley floor at the western wall of the Brazos River valley. Old River, a relic channel of the Brazos River, is ca. 50-75 $\mathrm{m}$ to the north, and the current Brazos River channel is ca. $6.1 \mathrm{~km}$ to the north. Old River flows into the Brazos ca. $23 \mathrm{~km}$ southeast of the site, just upstream from where Yegua Creek joins the Brazos. The Navasota River flows into the Brazos ca. $36 \mathrm{~km}$ southeast of the site.

As discussed in Chapter 2, the landform containing $41 \mathrm{BU} 51$ is mapped as a Pleistocene fluvial terrace deposit that extends ca. $15 \mathrm{~km}$ along the west margin of the Brazos River floodplain (Bureau of Economic Geology 1974). However, the sediments observed in the test excavations are more consistent with deposits of the Eocene Yegua Formation, which is mapped nearby, than with Pleistocene terrace deposits. According to the U.S. Department of Agriculture's Web Soil Survey, Silawa loamy fine sand soils, which are deep, sandy, well-drained terrace soils, are mapped for the site area.

Site 41BU51 is situated near the west margin of a narrow swath of Blackland Prairie that is inset into the Oak Woodlands of east-central Texas (Diamond et al. 1987). The Oak Woodlands region is characterized by mainly deciduous forests (greater than 60 percent canopy cover) of the overcup oak and post oak-black hickory series, and mainly deciduous woodlands (20 to 60 percent canopy cover) of the bluejack oak-pine and post oak-blackjack oak series. The Blackland Prairie is a tallgrass prairie characterized by the gamagrass-switchgrass, little bluestem-Indiangrass, and Silveanus dropseed series. Deciduous forests of overcup oak and post oak-black hickory are also found.

The project area is in the Texan biotic province, for which Blair (1950:101) notes at least 49 species of mammals. Blair (1950:101) and Davis (1974) have described this diverse mammalian assemblage as including whitetail deer, opossum, armadillo, raccoon, ringtail, weasel, mink, river otter, skunk, badger, red and gray fox, coyote, red and gray wolf, mountain lion, bobcat, ocelot, jaguar, beaver, peccary, bison, black bear, several species of bats, gopher, mole, squirrel, numerous species of mice and rats, rabbits, and jackrabbits. Bison and high-level predators have largely been extirpated. Other vertebrate fauna include at least 39 species of snakes and at least 41 species of lizards, skinks, box turtles, toads, frogs, and salamanders (Blair 1950:101-102). The region has 349 permanent or seasonal resident bird species and is within the Central Flyway, one of the four major bird migration routes in North America (Kutac 1994:47). Numerous freshwater fish and mussel species are also found in local streams and rivers (Chilton 1997; Howells et al. 1996).

The climate of the region is humid subtropical, with hot summers and mild winters. The average temperature is ca. $67 \circ \mathrm{F}$, with monthly averages ranging from $84 \mathrm{\circ}$ F in July to $47^{\circ} \mathrm{F}$ in January. The average annual precipitation is about $99.06 \mathrm{~cm}$ (39 inches), with a peak in the fall. Climate is mainly affected by the Gulf of Mexico, although strong fronts from the north can affect the region in the winter (Natural Fibers Information Center 1987:12, 73-74).

\section{NATIVE AMERICAN CULTURAL HISTORY}

This summary outlines the Native American cultural history of the southern part of eastcentral Texas and encompasses the stretch of the Oak Woodlands extending from Freestone and Navarro Counties on the north to Bastrop and Fayette Counties on the south, with Burleson County in the middle. The archeology of parts of this area is well understood because archeological investigations involving excavations have been undertaken. Projects that have contributed important information include those conducted at Richland-Chambers Reservoir in Freestone and Navarro Counties (Bruseth and Martin 1987; McGregor and Bruseth 1987); Lake Limestone in Leon, Limestone, and Robertson Counties (Mallouf 1979); Jewett Mine in Freestone and Leon Counties (Day 1984; Fields 1987, 1990; Fields and Klement 1995; Fields et al. 1991; Gadus et al. 2002); Calvert Mine in Robertson County (Davis et al. 1987; Robinson and Turpin 1993); Sandow Mine in Lee and Milam Counties 
(Ricklis 2001; Rogers 1997, 1999; Rogers and Kotter 1995); Gibbons Creek Mine in Grimes County (Rogers 1993, 1994, 1995); Somerville Lake in Burleson, Lee, and Washington Counties (Peterson 1965; Thoms and Ahr 1996); Cummins Creek Mine in Fayette County (Kotter et al. 1991); Fayette Power Plant in Fayette County (Skelton 1977); 41BU16 in Burleson County, 41MM340 and 41MM341 in Milam County, the Kennedy Bluffs and Bull Pen sites in Bastrop County, and the Black Hopper and Sandbur sites in Fayette County, all excavated because of Texas Department of Transportation projects (Bement et al. 1989; Ensor and Mueller-Wille 1988; Fullem 1977; Gadus et al. 2006; Kalter et al. 2005; Mahoney et al. 2003; Roemer and Carlson 1987); and miscellaneous excavations such as those at the Winnie's Mound and Frisch Auf! sites (Bowman 1985; Hester and Collins 1969).

Given its location, it is not surprising that the archeology of this region often has been seen as reflecting influences from adjoining regions with better-defined cultural histories. For example, Caddo influences predominate in the northern part of the study area, coastal influences are especially strong on the southeastern edge, and central Texas influences are most pronounced on the southern and western margins.

\section{Paleoindian Period (10,000-6500 B.C.)}

The earliest evidence of Native Amerian occupation of the southern part of east-central Texas is attributable to the Paleoindian period. Although archeological remains from this period are scarce, a variety of early points have been found, largely in mixed or surface contexts. Presumably, the area was used by huntergatherer groups with low population densities and high residential mobility. One significant early find, estimated to date between 10,000 and 8000 B.C., was at the Duewell-Newberry site in Brazos County (Carlson et al. 1984). The find consisted of mammoth remains deeply buried in Brazos River alluvium. Although no artifacts were found in association, some of the bones contained cut marks indicating human modification. Other early materials from the region include a few San Patrice points from Richland-Chambers Reservoir (McGregor and Bruseth 1987:176-179); one Folsom point from Lake Limestone (Mallouf 1979:44); a Golondrina point, several untyped lanceolate points, and a radiocarbon assay of 9200-7300 B.C. from the Lambs Creek Knoll site at the Jewett Mine (Fields 1995:304), as well as a Clovis point, a Meserve-Dalton point, and two San Patrice points from two other sites (Day 1984:83; Fields et al. 1991:317). Other artifacts include a San Patrice point and a Plainview-like point from the lowermost stratum at the Winnie's Mound site (Bowman 1985:44); a Plainview point and a Golondrina point from the Chesser site and a Clovis point and possible Clovis blade in redeposited contexts at 41LE177 at the Sandow Mine (Ricklis 2001:150; Rogers and Kotter 1995:134); a few Dalton and San Patrice points from sites at the Gibbons Creek Mine (Rogers 1995:166); a Dalton point from Somerville Lake (Thoms and Ahr 1996:13); a few Plainview and Meserve points from sites in the Fayette Power Plant project area (Skelton 1977:124); and a handful of points from the Sandbur site, including Clovis and Folsom preforms, a Dalton point, a Firstview point, a Wilson point, two Golondrina points, and a possible St. Mary's Hall point (Kalter et al. 2005:112-118).

\section{Archaic Period (6,500 B.C.-A.D. 700)}

Many of the excavated sites in the region have components dating to the Archaic period, and it is clear that the area supported sizable populations by the last third of the period. Materials dating to the early and middle parts of the period are widespread but not abundant. For example, the relatively intensive work at Richland-Chambers Reservoir and Lake Limestone and Jewett Mine at the north end of the region suggests limited use of the western edge of the Oak Woodlands before the Late Archaic. However, for both areas it has been noted that data pertaining to the early to middle parts of the Archaic may be scarce in part because sites dating to this interval lie deeply buried or were removed by extensive erosion during the mid-Holocene (Fields 1995:302; McGregor and Bruseth 1987:229). Only a few radiocarbon assays predating 2000 B.C. were obtained from these project areas, and only one excavated site, Charles Cox at the Jewett Mine, contains a substantial component that might be Early or Middle Archaic in age (Fields 1995:303-305). A variety of untyped dart points with expanding 
and parallel stems appear to represent this component, but later materials are mixed in as well, and the deposits were not dated by radiocarbon. Points dated to this interval in central Texas-for example, Bell, Andice, Calf Creek, and Hoxie-occur at both Richland-Chambers Reservoir and Jewett Mine, but only in very small numbers.

Similar conclusions can be reached for the other project areas listed above. The work at the Calvert Mine did not reveal evidence of significant Early to Middle Archaic occupations, and the evidence from most of the excavated sites at the Sandow Mine is limited as well-an early split-stem point, an Angostura-Hoxie point, and two Travis points from the Chesser site and a Martindale point from 41LE120 (Rogers 1997:52; Rogers and Kotter 1995:134). Site 41LE177 at the Sandow Mine contained an Early Archaic component represented by an Angostura point, an early split-stem point, a Uvalde point, two or three Hoxie points, and a hearth-debris cluster, as well as some perhaps redeposited Middle Archaic materials, including two Early Triangular points and a Travis point, but these components suffered from integrity and dating problems and were difficult to interpret other than noting that they probably reflected short-term occupations for hunting-related activities (Ricklis 2001:143, $145,150)$.

Early to Middle Archaic materials elsewhere in the region, all from sites that date predominantly later, include a Hoxie point from 41GM166 at the Gibbons Creek Mine (Rogers 1995:166-167); an Angostura-like point from Somerville Lake (Thoms and Ahr 1996:13); a few Travis, Nolan, Hoxie, and Uvalde points from the Cummins Creek Mine (Kotter et al. 1991:111, 124, 136); single Gower and Angostura points from the Fayette Power Plant (Skelton 1977:124, 125); and a Travis point from the Black Hopper site (Fullem 1977:11).

Three excavated sites with substantial Early to Middle Archaic components are Winnie's Mound, Kennedy Bluffs, and Sandbur, although the primary components at all three appear to be later. At Winnie's Mound, a Bell point, a Hoxie point, five Gower-Uvalde-like points, two Gower-like points, and five HoxieGower-Uvalde-like points were found in the lower strata, along with at least one hearth (Bowman 1985:43-47, 70). At Kennedy Bluffs, only a few Early to Middle Archaic points (one
Travis, one Tortugas-Taylor, two Angostura, one Gower-like, and one Nolan) were found in the area excavated, but many items dating to this interval were documented among the materials collectors recovered from another part of the site (Bement et al. 1989:35-36, 71-154). At Sandbur, one Angostura point, nine Bell/Andice points, one Hoxie point, one Merrill point, eight Wells points, and a single Early Triangular point were found, perhaps associated with burned rock concentrations (Kalter et al. 2005:118-124). Given the limited information available for this part of the period, it is difficult to say much about adaptations and lifeways. It does appear, however, that the region was used in a limited fashion, presumably reflecting low population densities among mobile hunter-gatherers.

The late part of the Archaic period-after about 2000 B.C. - presents a very different picture. All parts of the area that have been studied archeologically contain sites dating to this period, and the Late Archaic represents the earliest time for which much is known about Native American lifeways. One of the morecomplete pictures of the archeology of the Late Archaic for this region comes from the north edge of the area. Along Richland and Chambers Creeks, Late Archaic groups appear to have been hunter-gatherers whose subsistence pursuits focused on wild plant foods such as hickory nuts and prairie turnip and faunal taxa such as deer, turtles, small mammals, birds, and fish (McGregor and Bruseth 1987:236-240). Although presumably not sedentary, these groups clearly used the area for residential purposes, and populations appear to have increased. A conspicuous component of the record is the so-called Wylie pit, examples of which were excavated at the Bird Point Island and Adams Ranch sites. These were large features that appear to have been used for communal processing of vegetal resources (and later as cemeteries), perhaps in the context of band aggregation in tension zones as territories decreased in size (McGregor and Bruseth 1987:237).

The Navasota River valley and the area eastward to and across the Trinity River divide also were occupied with increased intensity during the Late Archaic period (Fields 1995:307-309), although there is no evidence for the kind of population aggregations indicated at Richland-Chambers Reservoir. Faunal and macrobotanical remains were not preserved in 
the Late Archaic components at Lake Limestone and Jewett Mine, except for the ubiquitous hickory nuts, and thus data on subsistence are limited. Nonetheless, it is surmised that these hunter-gatherers subsisted on a variety of wild plant foods and game, especially deer. Of the 20 excavated components assigned to this period, 15 are interpreted as residential bases and 5 as procurement or processing locations. Five of the residential-base components are situated along the Navasota River and appear to represent general-purpose campsites, and the others are in the uplands to the east and consist of 2 general-purpose residential bases and 8 residential bases at which activities focused heavily on plant processing and secondarily on hunting. This distinction suggests that Late Archaic settlement systems were based on the occurrence of plant foods. The analysis units interpreted as procurement-processing locations appear to have focused primarily on plant processing and then on hunting-related activities. Four of these are along streams in the uplands, and the fifth is along a Navasota River tributary to the west. The data from these 20 components are consistent with the idea that Late Archaic groups were chiefly foragers because procurement-processing locations suggesting logistical use are not frequent. Settlement systems appear to have been highly scheduled, probably by season, with residential sites in riverine settings differing from those in the uplands. Comparisons with earlier components at Lake Limestone and the Jewett Mine are difficult, but the much greater frequency of Late Archaic components and the overall greater intensity of use suggest increased population densities, decreased territories, or both. The occurrence of a Late Archaic cemetery at the Cottonwood Springs site along Lambs Creek on the east side of the Navasota River valley also points to this shift (Fields and Klement 1995).

Not only do constellations of projectile point styles (e.g., Dawson, Gary, Godley, Kent, Neches River oletha, and Yarbrough) from the RichlandChambers, Lake Limestone, and Jewett Mine areas indicate ties to the north and east rather than to the south and west, but each of these areas also has yielded information suggesting that ceramics may have been introduced into the material culture of local groups during the latest part of the Late Archaic, as they were across most of Texas to the east (where this interval usually is called the Early Ceramic period and sometimes the Woodland period).

At Richland-Chambers Reservoir, distinctive shell-tempered sherds were recovered from contexts dated between A.D. 200 and 700 at the Adams Ranch site (McGregor and Bruseth 1987:180-181), apparently representing the earliest ceramic industry in this part of the Trinity River basin. At Lake Limestone and the Jewett Mine, a few shell-tempered sherds, a few sherds with a fine kaolin paste but no obvious temper, and larger numbers of sandy paste ceramics and grog- or bone-tempered ceramics were found in contexts that appeared to predate arrow points (i.e., the latter part of the Late Archaic). Although some of these could be genuinely early, especially the sandy paste wares that are so reminiscent of the early ceramics that predominate in east Texas south of the Sabine River, it is possible that the other sherds intruded from later deposits (Fields 1995:308). In either case, sherds were sufficiently infrequent to suggest that, although ceramic containers may have been a notable addition to the material culture, they were not abundant.

The Late Archaic archeology of the other project areas in southern east-central Texas has not been deciphered to the same extent as that at Richland-Chambers Reservoir and Jewett Mine, but it is clear that similar, though not identical, cultural developments occurred within huntergatherer groups across the region. The single excavated site at the Calvert Mine, 41RT267, apparently contains a Late Archaic component, but small sample sizes and the lack of features hamper interpretation (Robinson and Turpin 1993). Two of the excavated sites at the Sandow Mine-the Chesser site and the Walleye Creek site-contained abundant Late Archaic remains. At these sites, many burned rock features were found in association with dart point types such as Bulverde, Pedernales, Lange, Marshall, Marcos, Ensor, Darl, and Fairland (Rogers 1999:96; Rogers and Kotter 1995:134). Although these types show distinct ties to central Texas in general, Rogers (1999:96-97) argues that the last three represent more-local types especially common to the eastern margin of the Edwards Plateau. Site 41LE177 at the Sandow Mine yielded only one Bulverde point and apparently did not see substantial use during the Late Archaic period (Ricklis 2001:150). A single sandy paste sherd was recovered from the Chesser site, but it is 
unclear if it relates to terminal Archaic or Late Prehistoric use of the site. In either case, ceramics were a less-prominent part of the material culture here than they were farther to the east and north. The limited faunal and macrobotanical remains recovered suggest reliance on Carya nuts and deer (Rogers 1999:28, 31-32; Rogers and Kotter 1995:42-45, C-1-10).

To the east, two sites along the Brazos River-Winnie's Mound and 41BU16-have significant Late Archaic components (Bowman 1985; Roemer and Carlson 1987). ${ }^{1}$ Perhaps most important, both contained cemeteries probably at least partly Late Archaic in age. Cemeteries here and elsewhere across the region perhaps represent increased population densities and definition of territories. The projectile point styles recovered-Bulverde, Darl, Dawson, Edgewood, Ensor, Fairland, Frio, Gary, Kent, Lange, Marcos, Pedernales, and Yarbrough-are a mix of types characteristic of central and eastern Texas. Winnie's Mound yielded a few sandy paste sherds, and 41BU16 contributed a larger ceramic collection that is hard to relate typologically to ceramics in surrounding regions.

Not far north on the Little River in Milam County, both 41MM340 and 41MM341 have Late Archaic components, although only the one at 41MM340 was investigated intensively (Gadus et al. 2006; Mahoney et al. 2003). This site, which was occupied from about 1400 to 400 B.C., contained numerous hearth features represented by both burned rock clusters and charcoal and burned clay concentrations. Subsistence data indicate that the hunter-gatherers who occupied the Little River valley at this time consumed the meat of a variety of fauna, including mussels, deer, bison, turtles, beaver, rabbits, raccoon, opossum, skunk, turkey, ducks, and fish. Botanical remains were not as abundant, although nutshell fragments indicate that hickory and pecan nuts were part of the diet. Most of the dart points belong to types that firmly tie the region to central Texas to the west at this time, including Darl, Ensor, Godley, Marcos, Marshall, and especially Pedernales. Some more-eastern types, such as Gary, Kent, and Yarbrough, are represented, however.

At the Gibbons Creek Mine on the east edge of the study area, most of the excavated sites have Late Archaic components, and Rog-

1 As discussed later in this report, 41BU51 can be added as a third site in this list. ers (1995:167) suggests that this reflects "a less mobile population relying more heavily on the area's plant resources, particularly hickory nuts." Rock hearths are common at these sites, but other kinds of features are not. Not surprisingly, the most common dart point types-Gary, Kent, and Palmillas-show strong connections to the eastern part of the state rather than to central Texas (Rogers 1995:167). As at Jewett Mine and Richland-Chambers Reservoir to the north, ceramics may have been added to the material culture during the latest Archaic. These early ceramics were sandy paste wares comparable to early ceramics elsewhere in southeastern Texas (Rogers 1995:167).

At Somerville Lake on Yegua Creek, the single site excavated, Erwin's Bridge, contained many Late Archaic artifacts, although it was difficult to isolate this component from the Late Prehistoric component (Peterson 1965). Most of the kinds of projectile points recovered-Bulverde, Castroville, Darl-like, Elam, Fairland, Palmillas, and Pedernales-resemble those from the Sandow Mine not far to the northwest, with both collections indicating ties to central Texas to the west. Erwin's Bridge yielded a small collection of ceramics, primarily sandy paste, but it is impossible to tell if these relate to the Late Archaic or Late Prehistoric occupations.

Moving farther south into the Colorado River basin, the Kennedy Bluffs and Bull Pen sites in Bastrop County, most of the tested sites at the Fayette Power Plant and the Cummins Creek Mine, and the Sandbur site in Fayette County have Late Archaic components. Both the Kennedy Bluffs site and the Bull Pen site, and perhaps the Sandbur site, contained evidence of extensive use of burned rock features associated with point styles typical of central Texas to the west, especially Pedernales. Other point types include Bulverde, Marcos, Montell, and Marshall-like at Kennedy Bluffs; Ensor, Fairland, and Darl at Bull Pen; and Lange, Marshall, Castroville, Montell, Marcos, Ensor, Fairland, Darl, and Godley at Sandbur (Bement et al. 1989:21-30, 37-44; Ensor and MuellerWille 1988:181-183; Kalter et al. 2005:124-133). These sites have been interpreted as seasonal base camps used repeatedly by hunter-gatherers for a variety of maintenance, extractive, and processing tasks (Ensor and Mueller-Wille 1988:183-200). At the Fayette Power Plant, a number of sites yielded similar styles of points- 
Pedernales, Marshall, Ensor, Darl, and Fairland. The last three types were especially common and indicated "a marked increase in site utilization and exploitation of the local resources" during terminal Archaic times (Skelton 1977:125-126). Several of the tested sites at the Cummins Creek Mine contained Darl, Ensor, Pedernales, and Mahomet points and were interpreted as having been used as short-term campsites during the Late Archaic period (Kotter et al. 1991:118-119, 159-160, 177).

\section{Late Prehistoric Period (A.D. 700-1680)}

Sites dating to the Late Prehistoric, after ca. A.D. 700, also are common across most of the region. As for the preceding period, good data on how Native Americans used the north part of the area comes from Richland-Chambers Reservoir and Lake Limestone and nearby Jewett Mine. Sites dating to this interval are frequent at Richland-Chambers Reservoir, especially for the early half of the period, and it appears that there was a significant decline in population densities after about A.D. 1300 (McGregor and Bruseth 1987:245). The data suggest that most of the excavated sites with Late Prehistoric components were used for residential purposes (McGregor and Bruseth 1987:241, 244, 246), although there are some sites, for example the streamside concentrations of mussel shells and artifacts at $41 \mathrm{FT} 193$ and $41 \mathrm{NV} 139$, that probably had more-limited use. The house patterns at the Bird Point Island site point to use by sedentary hunter-gatherers during the first half of the period, and other components that are contemporaneous, slightly earlier, or later (for example, at Bird Point Island, Adams Ranch, Irvine, and Little Cedar Creek) have middens and many features suggesting substantial use but no houses. These components may represent occupations that were seasonal in length. Macrobotanical remains point to use primarily of wild plant foods-hardwood nuts, a variety of seeds, tubers, and rhizomes (McGregor and Bruseth 1987:243). The only tropical cultigen is maize, and it occurs in very small quantities only in contexts dating to the last half of the period, so groups who lived in this area were predominantly hunters and gatherers. Alba, Scallorn, and Steiner arrow points were used during the early part of the period, and Perdiz and Cliffton points are more characteristic of the late part. Gary dart points may have been used through the early Late Prehistoric (McGregor and Bruseth 1987:183). Ceramics are moderately common and clearly relate to Caddo wares, with most of the identified types (for example, Maydelle Incised, Poyner Engraved, and Weches Fingernail Impressed) indicating contact with groups in the Neches River drainage, east of the Trinity.

Work at Lake Limestone along the Navasota River and Jewett Mine in the uplands to the east identified 12 components dating predominantly to the Late Prehistoric period, although not all are well dated (Fields 1995:313-317; Gadus et al. 2002). Six are interpreted as residential bases, and the other 6 are procurement-processing locations. These sites suggest that the Late Prehistoric period saw a change in settlement strategies from the Late Archaic and that there were changes within the Late Prehistoric period as well. During the early part of the period, residential activities were increasingly restricted to lowland sites, while the uplands were used mostly for hunting-related procurement and processing tasks. This pattern indicates that logistical strategies became more important, but there is no evidence that groups also became more sedentary within the upper Navasota River basin itself. Only one site, McGuire's Garden, contained the kinds of features and other remains that suggest permanent (or nearly so) occupation, with this unusually sedentary use dating to a short interval around A.D. 1300 (Gadus et al. 2002:155). During the late part of the period, the area apparently saw a return to forager-oriented hunter-gatherer strategies entailing more equable use of upland and lowland settings. Faunal remains indicate that deer, turtles, and rabbits were hunted commonly, and other small mammals, bison, fish, birds, lizards, and snakes were represented as well. Hickory nutshells are by far the most common plant remains. The only evidence for horticulture is from the McGuire's Garden site. Scallorn and Steiner are the most common early arrow point styles, and use of dart points appears to have persisted through the early part of the period (Fields 1995:314). Perdiz is the dominant later arrow point style. Ceramics occur widely but infrequently, being common at only a handful of sites that date mostly to the middle and late parts of the period. Nonetheless, they all relate strongly to Caddo wares from east of the Trinity 
River, with the more-distinctive sherds showing typological affinities to early types such as Holly Fine Engraved and Weches Fingernail Impressed and later types such as Maydelle Incised, Killough Pinched, Poyner Engraved, and Patton Engraved. Because Caddo ceramics are present in these components but evidence for permanent occupations (i.e., structures) is scarce, Fields et al. (1991) suggested that Caddo Indians used most of these sites as base camps to support forays by hunting parties or other procurement and processing task groups, or perhaps groups in transit between the eastern and central parts of the state used them. It is equally plausible, however, that local hunter-gatherer groups created them and that the ceramics resulted from trade or borrowing of ideas about ceramic manufacture and decoration.

At the Calvert Mine in the uplands between the Brazos and Navasota Rivers, the primary component at the single excavated site, 41RT267, appears to date to the early Late Prehistoric period (Robinson and Turpin 1993:23-69). It contained Scallorn, Alba, and Granbury points, as well as a single sherd and several burned rock features, and was interpreted as having been used mostly as a hunting camp with occasional use as a domestic campsite (Robinson and Turpin 1993:71-72).

Moving southwestward across the Brazos River, 41MM341 on the Little River has a significant early Late Prehistoric component dating mostly from A.D. 800 or 900 to 1300 (Gadus et al. 2006). This site contains numerous surface hearths, pit hearths, processing pits, shell lenses, burned rock concentrations, possible postholes, and lithic reduction debris piles. Arrow points are typed primarily as Scallorn, Alba, and Perdiz, and the site also contained many finely chipped bifacial knives. Three bone-tempered sherds and one sandy paste sherd were recovered, but it is not clear if they belong with the early Late Prehistoric component or a much sparser later component. Site 41MM341 is interpreted as a campsite occupied perhaps mostly during the summer months by hunter-gatherers who took mussels and fish from the river and hunted a variety of game, especially deer, on the Little River floodplain and the surrounding uplands. They may have used botanical resources less, although they did consume hardwood nuts and wild onion and false garlic bulbs. One important activity performed at the site was manufacture of stone tools, mostly arrow points, knives, and expedient flake tools, using chert collected from gravel bars in the river. Many of these tools were used in the wide variety of procurement, processing, and manufacturing activities that typified daily life at 41MM341, but some appear to have been made because they would be needed later in the year after people left the site. One anticipated need was for trade with the Caddo Indians of east Texas. The evidence indicates that the people who lived at 41MM341 and other sites in the Little River valley interacted regularly with the Caddo, perhaps in trade relationships that helped cement cooperative alliances aimed at regulating competition among groups.

Farther south at the Sandow Mine, all three excavated sites have Late Prehistoric components, but they do not appear to represent intensive use. Materials diagnostic of this period include small numbers of Scallorn, Perdiz, Alba, and Cuney points; ceramics are scarce to absent (Ricklis 2001:150; Rogers 1999:96; Rogers and Kotter 1995:136). At Somerville Lake not far to the southeast, arrow points typed as Alba, Cliffton, Granbury, Perdiz, Scallorn, and Young were recovered from the Erwin's Bridge site, along with a handful of undecorated sherds (Peterson 1965:22-27, 36-43); small numbers of Alba, Scallorn, Perdiz, and Bonham points and sandy paste sherds were found at other sites Thoms and Ahr (1996) recorded in this area.

Eastward along the Brazos, early Late Prehistoric components represented by small numbers of Scallorn points, a few sandy paste sherds, and burials were documented at Winnie's Mound (Bowman 1985:43, 50, 61-63). Alba, Perdiz, and Scallorn points were found at 41BU16 nearby, along with both sandy paste and bone- or grog-tempered ceramics (Roemer and Carlson 1987:80-93); some of the burials at 41BU16 could relate to the Late Prehistoric component as well.

At the Gibbons Creek Mine at the southeast edge of the area, Late Prehistoric remains are well represented, with substantial occupations at 41GM281 and 41GM282 and more-limited occupations at several other sites (Rogers 1993:77, 102, 174, 214, 1994:154, 1995:138-143, 164-165). The predominant early and late arrow point styles are Scallorn and Perdiz, respectively. The ceramics from most of the excavated sites (Rogers 1993:102, 160-173, 210-212, 1994, 1995:108-123, 168-171) are the sandy paste 
ware that occurs throughout southeast Texas, first in Late Archaic (or Woodland or Early Ceramic) contexts and then in some Late Prehistoric contexts (e.g., on the upper coast). Two sites (41GM281 and 41GM282) also have sizable samples of pottery tempered with grog or bone. Some of these probably are related to the Late Prehistoric San Jacinto ware that occurs on the upper coast to the east and southeast, and small numbers of sherds bear designs similar to those seen on Caddo pottery to the northeast. Subsistence data from the Gibbons Creek Mine are especially sparse, but hardwood nutshells occur in most sites and liliaceous bulb fragments were recovered from a single site (Rogers 1993:74, 124, 214, 1994:120, 149, 1995:56, 153). Consistent with the lack of cultigens at Gibbons Creek is the low stable carbon isotope value on human remains from a Late Prehistoric burial at 41GM205 (Rogers 1993:D-1 through D-3). The combined evidence indicates that, for the most part, the Gibbons Creek sites represent short-term residential occupations by huntergatherers.

In the Colorado River basin at the south end of the study area, Late Prehistoric components are well represented at comparatively few sites. At the Cummins Creek Mine, only one minor Late Prehistoric occupation is represented by a single untyped arrow point from one of the four sites tested (Kotter et al. 1991:154). The Black Hopper, Kennedy Bluffs, and Bull Pen sites all contained sparse Late Prehistoric materials indicating limited occupations; arrow point types consisted of Scallorn, Perdiz, and Granbury, with none of the sites yielding ceramics (Bement et al. 1989:47; Ensor and Mueller-Wille 1988:116-118; Fullem 1977:12-13). The most substantial excavated Late Prehistoric components in this area were at the Cedar Bridge site at the Fayette Power Plant (Skelton 1977:127-128) and the Sandbur site (Kalter et al. 2005:217-221), where Toyah occupations represented by Perdiz arrow points, bone-tempered ceramics, and bison bones were sampled. Sandbur also contained an earlier Late Prehistoric component represented mostly by Scallorn points, and maybe by sandy paste pottery. Another important Late Prehistoric component in the area was at the Frisch Auf! site, where Scallorn points and bone-tempered ceramics were found in association with a cemetery (Hester and Collins 1969).

As noted above, an important issue relating to the Late Prehistoric archeology of this part of the Oak Woodlands concerns the relationships between groups who lived in this area, and on the Blackland Prairie to the west, and Caddo groups who lived to the east. In most cases, the presence of Caddo artifacts west of the Caddo heartland has been seen as reflecting the movement of Caddo hunters or traders, which was well documented in early historic narratives, and perhaps the establishment of seasonal or year-round occupations at some locations. Adopting a different perspective on the movement of peoples and goods, Harry Shafer (2006) has proposed that the groups who used some of these western sites with Caddo materials during the period from A.D. 1000 to 1300 were Caddo people who were local to the area and who served as the sustaining population for the ceremonial center at the George C. Davis site in Cherokee County far to the east. This "Prairie Caddo" model is based in part on the limited evidence of habitation sites of the right age near the Davis site and the prevalence of an artifact assemblage that Shafer sees as the material correlate for a Prairie Caddo social identity. This assemblage includes Caddo vessel ceramics similar to those found at the Davis site, Alba-Bonham arrow points, Gahagan knives, and bone needles and metapodial beamers representing the manufacture of fine deer-hide clothes. Items within this assemblage (except beamers) occur at the Davis site both in burial and nonburial contexts (Shafer 1973; Story 1972), and Shafer (2006) demonstrates that these items are common at Blackland Prairie sites along and just east of the Balcones Escarpment, although they do not always (or maybe even often) occur together.

While acknowledging that parts of Shafer's Prairie Caddo proposal are compelling, Gadus et al. (2006:177-181) offer an alternative interpretation, arising from their analysis of the J. B. White site (41MM341) on the Little River at the boundary between the Oak Woodlands and the Blackland Prairie. They conclude that the Little River valley and those of its tributaries were used in a consistent fashion by local huntergatherer groups who were well-adapted to the Blackland Prairie and the ecotonal areas at its east and west margins from at least A.D. 600 to 1300 , with consistency farther back into Late Archaic times suggested by 41MM340 nearby.

Among the resources that these people knew how to exploit were the local chert gravels. 
By A.D. 1100 or a century or two earlier, they were using these gravels to make not only tools for their own use but also as goods to be used during interactions with the Caddo. This production involved particular tools following specific technological styles, but the evidence for interaction involving lithics not manufactured to such specifications (and not focused so strongly on a single east Texas site) goes much farther back in time, suggesting that this pattern of connections between the eastern margin of central Texas and the eastern part of the state was a persistent one rooted in long-held traditions. This has been documented, for example, at the Jewett Mine in Freestone and Leon Counties, where a number of caches of bifacial and unifacial tool blanks of central Texas materials have been found, and where large quantities of debitage reflecting the staged reduction of central Texas cherts have been identified in sites of various ages, including some dating to Late Archaic and even earlier times (Fields 1995:325). As noted above, ethnohistoric accounts indicate that substantial interaction between the two regions continued up to historic times, primarily in the form of Caddo groups traveling westward to hunt and trade. The reasons for this interaction may have changed over time, but the persistence of the pattern did not.

Contrary to what the Prairie Caddo model proposes, Gadus et al. (2006:177-181) think that the people who lived along the Little River in early to middle Late Prehistoric times were not ethnically Caddo peoples who provided support for the ceremonial center at the Davis site. Rather, they suggest they were a local group well adapted to their particular environs who interacted regularly with the east Texas Caddo, probably in simple face-to-face or maybe downthe-line trade relationships with limited dependencies and great group autonomy. This model also can be applied to groups who occupied the Brazos River valley during this time, including those who created 41BU51.

\section{Historic Period (A.D. 1680-1750)}

Native American archeological materials dating to the protohistoric and early historic periods are scarce in southern east-central Texas. In fact, materials of this age are so rare as to be almost invisible archeologically in the project areas discussed above. But ethnohistoric accounts make it clear that historic Native Americans, both resident groups and immigrants, occupied the area (Bolton 1970; Campbell 1988; Foster 1998; Newcomb 1993). Further, three historic routes from south Texas to east Texas-Camino de los Tejas, Camino Arriba, and La Bahia Road-passed through present-day Bastrop, Brazos, Burleson, Fayette, Grimes, Lee, Leon, Madison, Milam, Robertson, and Washington Counties by the seventeenth and eighteenth centuries (McGraw et al. 1991:9; Thoms 1993:12, 22). In the late 1740 s and early 1750 s, the Spanish located three missions-San Francisco Xavier de Horcasitas, San Ildefonso, and Nuestra Señora de la Candelaria-and a presidio (San Francisco Xavier de Gigedo) near one of these routes, not far from where Brushy Creek joins the San Gabriel River in Milam County (Gilmore 1996a, 1996b). The impetus for this came when members of the Yojuane, Deadose, Mayeye, and Ervipiame asked that a mission be established in their territory. Other Native American groups reportedly associated with the missions were the Asinia, Top, Nabedache, Akokisa, Bidai, and Coco. For a variety of reasons, the Spanish had abandoned their efforts along lower Brushy Creek by the mid-1750s (Newcomb 1993:16-17). 


\section{WORK ACCOMPLISHED AND SUMMARY OF RESULTS}

\section{FIRST PHASE OF TESTING}

The first phase of test excavations was performed from February 3 to March 14, 2003, under Contract No. 573XXSA001, Work Authorization 57301SA001, and Texas Antiquities Permit No. 3030 (Fields et al. 2003). The work authorization called for assessment of the entire horizontal and vertical extent of the site. It stipulated excavation of four backhoe trenches; four initial $1 \times 1-m$ test units adjacent to the trenches, extending from the ground surface to the basal clay; and up to two blocks of contiguous 1x1-m units around the most productive of the initial units.

\section{Work Accomplished}

Testing began with the placement of four backhoe trenches (Trenches 1 through 4, 18$28 \mathrm{~m}$ long and 1.0-1.2 m wide) across the undisturbed horizontal extent of the site (Figure 2.1). Trench 1, which measured $26 \mathrm{~m}$ long, was on the north slope of the ridge above the Old River floodplain. It reached the red sandy clay bedrock at depths of 90-105 cm at the west end and $20-30 \mathrm{~cm}$ at the east end. A dark brown paleosol was observed in the trench walls extending 20-70 $\mathrm{cm}$ above the red clay and increasing in thickness westward (downslope). Charcoal and a burned rock were observed in the south wall, spurring the placement of Test Unit 1 . Test Unit 1 , dug in 10-cm levels (as were all of the manual excavations), reached $110 \mathrm{~cm}$ below the surface, with undulating red clay pockets encountered $80-90 \mathrm{~cm}$ below the surface.

Trench 2 , which was $28 \mathrm{~m}$ long, was placed ca. $7 \mathrm{~m}$ north of the large borrow pit that occupies the central part of the site, overlapping a trench excavated during survey investigations in 2002 where many flakes and a Godley dart point were collected. Trench 2 encompassed the 7-mlong old trench and extended $8 \mathrm{~m}$ east and $13 \mathrm{~m}$ west. A paleosol was observed at $110-170 \mathrm{~cm}$ below the surface, tapering westward as the red clay sloped upward. Test Unit 2 was placed on the south side of the trench to investigate the relatively thick paleosol and the overlying sands, and Test Unit 5 was placed immediately to the east. Test Unit 2 reached a depth of $170 \mathrm{~cm}$, and Test Unit 5 was excavated to $150 \mathrm{~cm}$.

Trench 3, which measured $24 \mathrm{~m}$ long, was placed on the ridge top ca. $5 \mathrm{~m}$ south of the borrow pit. The profile revealed $60 \mathrm{~cm}$ of sand overlying red clay at the east end, but the west end was only $30 \mathrm{~cm}$ deep. Test Unit 3 was placed on the north side of the trench, ca. $2 \mathrm{~m}$ west of the east end of the trench, and reached a depth of $60 \mathrm{~cm}$.

A fourth trench was planned on the far southern extent of the site in the vicinity of a trench excavated during the survey phase. That trench exposed thin $(60 \mathrm{~cm})$ Holocene deposits with sparse cultural materials over red clay. However, access to this property was denied during the testing phase. Due to the shallow deposits found in the survey trench, the similarities between the profiles of this trench and testing Trench 3, and the lack of access to the southernmost portion of the site, Trench 4 was reallocated to the main part of the site north of the borrow pit. It was placed perpendicular to Trench 1, along the eastern edge of the proposed right of way. This trench, which measured 18 $\mathrm{m}$ long, exposed 100-120 $\mathrm{cm}$ of sand over red sandy clay, with a paleosol only $3-8 \mathrm{~cm}$ thick just above the clay. A dark soil stain (Feature 1) was observed in the floor of the trench, and Test Unit 4 was placed by the stain to investigate this area. Test Unit 4 reached a depth of $110 \mathrm{~cm}$.

The four initial test units revealed that, contrary to what was suggested by the 2002 


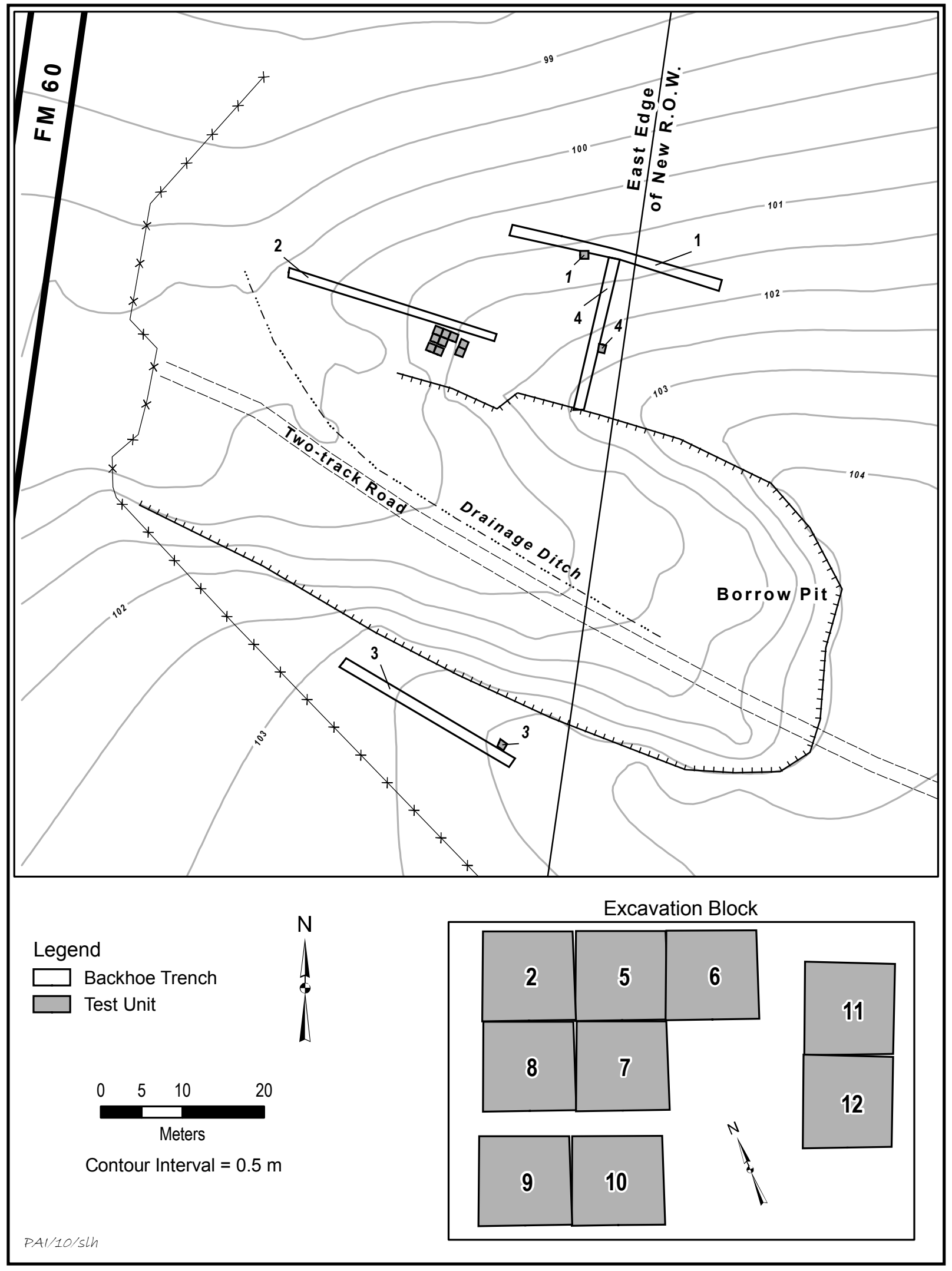

Figure 2.1. Map showing excavations in the first phase of testing. 
survey investigations, the archeological remains are not restricted to a discrete zone just above the tan sand-red sandy clay contact. Instead, artifacts were found throughout the sandy mantle. Based on the information from Test Units 1-4, it was determined that the area of Test Unit 2 along the east end of Trench 2 would be most productive for block excavations aimed at recovering enough information to allow full assessment of the site. This conclusion was based on the following considerations: (1) the sands overall and the paleosol at the base of the sands were thickest here, affording the best possibility of identifying stratification in the cultural deposits; and (2) Test Unit 2 contained higher densities of artifacts (including three diagnostic projectile points) and other cultural materials (such as burned clay) than the other three units, suggesting that this area contained relatively abundant information on the components present and their chronology.

Test Units 5-12 were placed around Test Unit 2 to constitute a block unit; these units were dug to depths of $120-150 \mathrm{~cm}$, somewhat shallower than Test Unit 2, because they were upslope where the sands were thinner and because they were not taken below the undulating contact between the tan sands and the red sandy clay. Because the sands in this area were thick and poorly consolidated, these excavations were accompanied by safety benching around the north, east, and south sides of Trench 2. Still, slumping occurred, which explains why Test Units 9-12 are offset from the others in the block (see Figure 2.1).

\section{Geomorphology}

The ridge upon which $41 \mathrm{BU} 51$ rests is mapped as part of a Pleistocene fluvial terrace deposit that extends ca. $15 \mathrm{~km}$ along the west margin of the Brazos River floodplain and is ca. $3 \mathrm{~km}$ wide in the vicinity of the site (Bureau of Economic Geology 1974). The sediments observed in the testing trenches, however, seem more consistent with deposits of the Eocene Yegua Formation, which is mapped ca. $2.5 \mathrm{~km}$ to the southwest, than with Pleistocene terrace deposits. In any case, the basal red sandy clay that underlies 41BU51 is ancient and not of a culturally relevant age. The sands that mantle the site, and the processes by which those sands have accumulated, are relevant, though, since they are of Holocene age and contain abundant archeological remains.

Profiles of three trenches are presented in Appendix A, providing a north-south transect from the slope above the Old River floodplain (Trench 1) up onto the ridge north of the borrow pit (Trench 2) and then to the ridge top south of the borrow pit (Trench 3 ).

The archeological remains at 41BU51 are contained in a late Holocene mantle of colluvium and slopewash consisting of brown to dark brown fine sand (AE horizon) and an underlying dark grayish brown to very dark grayish brown loamy fine sand (B or Bt horizon). The B horizon displays few to common clay lamellae, or illuvial clays. Occasionally, the clay bands are numerous enough that the $B$ horizon qualifies as a Bt horizon.

This late Holocene mantle overlies a very dark grayish brown sandy clay loam or very dark gray sandy clay representing a buried soil, designated a $2 \mathrm{Ab}$ horizon (Figure 2.2). This soil is not present across the entire site, as it has been eroded away in some places. It is presumed that the soil imprint formed on an earlier sandy colluvial-slopewash unit, presumably pre-late Holocene in age ( $>4,500$ B.P.). Underlying the buried soil, or the late Holocene sandy mantle where the buried soil has been removed, is the sandy clay bedrock, usually imprinted with a truncated ancient soil. As noted above, this appears to be of Eocene age. The topography of the bedrock surface does not mimic the topography of the modern ground surface (the sand mantle varies greatly in thickness), presumably reflecting ancient erosion of the bedrock surface and subsequent accumulation of the overlying sands.

The precise geomorphic processes active in the sand mantle region of east-central Texas remain a matter of debate. Some argue that the sand mantle is not a depositional unit at all, but simply in situ ancient deposits freed up by weathering of the sandy bedrock (Brown 1975; Bruseth and Martin 2001). Others have shown convincingly that, at least in places, the sands consist of late Holocene colluvium that has buried archeological sites, sometimes with good integrity and sometimes not (Fields and Klement 1995:54-55; Frederick et al. 2001). Thoms (1993), working on the east wall of the Brazos valley northeast of the current project area, proposed a model that emphasizes pedo- 
turbation, graviturbation, and gullying as agents for burial of archeological materials. Elements of Thoms's model probably apply at 41BU51, as there is ample evidence of turbation of various sorts as well as erosional sculpting of the Eocene bedrock. However, the presence of the paleosol in Trenches 1, 2, and 4 clearly shows that the sands above are depositional. The most likely sources of these sands are the slightly higher upland surfaces to the south and west, and the most likely processes for their transport are colluvial and sheetwash.

\section{Features}

Two features were identified during the first phase of testing. Feature 1 was a $62 \mathrm{~cm}$ (east-west) by $92 \mathrm{~cm}$ (north-south) oval area of darker sand intruding into the basal clay, located just west of Test Unit 4, at the bottom of Trench 4, at $112 \mathrm{~cm}$ below ground surface. It was cross-sectioned manually to a depth of ca. $65 \mathrm{~cm}$ below the base of the trench, revealing sandy sediments with clay lamellae but no red sandy clay margins (i.e., pit walls) and no artifacts. A backhoe then was used to enlarge and deepen the cross section. This exposure, extending $2+\mathrm{m}$ below the bottom of the trench, suggested that the sandy sediments with lamellae below the red sandy clay are actually Eocene bedrock, and that the dark stain likely represents a natural intrusion into the bedrock, such as a scar from an uprooted tree. Feature 2, a cluster of bones originally thought to be faunal remains but later identified as a human burial (Burial 1 ), was found in Test Unit 8; it is described in Chapter 3.

\section{Artifacts}

Cultural materials collected during this phase of testing consist of lithic debitage, lithic tools, ground stones, ocher, ceramic sherds, burned clay nodules, burned rocks, and small amounts of charcoal and animal bones. By far the largest artifact category is lithic debitage.

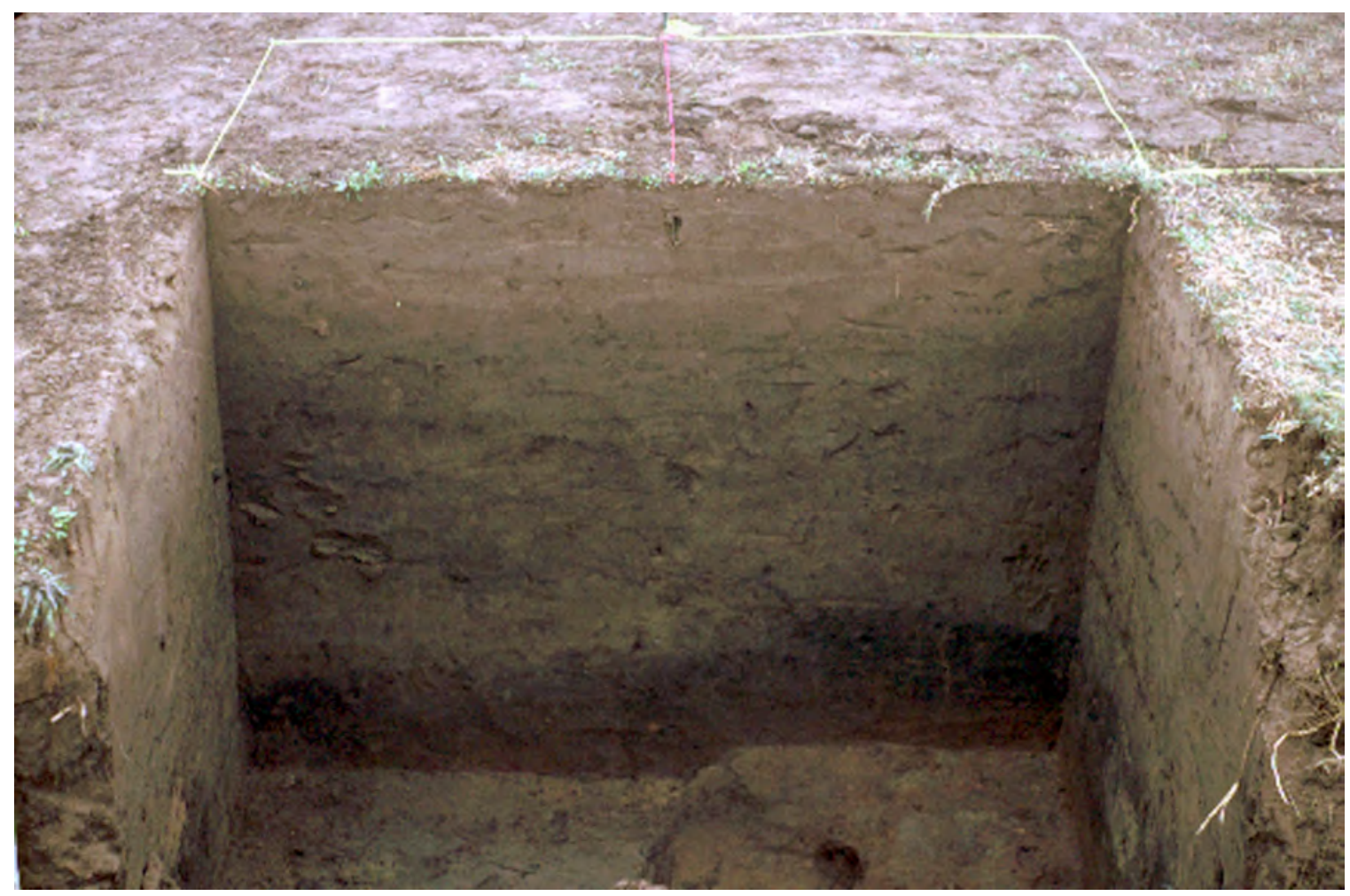

Figure 2.2. Photograph of the south walls of Test Units 2 and 5; note the 110-cm-thick brown to dark grayish brown sandy $\mathrm{AE}$ and $\mathrm{Bt}$ horizons above the very dark gray clayey $2 \mathrm{Ab}$ horizon. 
These materials are described in Chapter 4, and their distributions and the information they convey about the chronology and function of the site are discussed in Chapter 5.

\section{Initial Site Assessment}

Based on the initial testing results, 41BU51 appeared to have a limited capacity to contribute important information concerning the prehistory of this stretch of the Brazos River valley. The foremost reason for this assessment was the difficulty of isolating discrete components, which stemmed from the following factors: (1) perhaps because of extensive bioturbation, the site apparently lacks the kinds of cultural features, such as hearths and pits, that would allow living surfaces or cultural zones to be identified; (2) artifacts occur in moderate to high densities vertically throughout the deposits, without distinctive frequency peaks that would allow correlation between units; (3) the cultural deposits generally lack well-defined stratigraphy that could help sort the archeological remains into useful analytical units; and (4) the late Holocene colluvium and underlying paleosol are poorly consolidated and obviously disturbed by rodent burrowing and other agents of bioturbation, increasing the potential that artifacts have moved both horizontally and vertically.

Other factors also argued that the site had a limited capacity to contribute important information. First, charcoal is poorly preserved, making it difficult to use radiocarbon dating to establish a firm chronology for the site. Second, faunal and macrobotanical remains, which would provide information on subsistence resources used, are sparse. Third, well over half of the part of the site within the current project area was removed decades ago with excavation of the large borrow pit that bisects the project area, thus complicating interpretation of the part of the site that remains. For these reasons, 41BU51 was considered ineligible for listing in the National Register and designation as a State Archeological Landmark, and no further work was recommended.

\section{Need for a Second Phase of Testing}

After submittal of the interim report on the first phase of testing, laboratory analysis revealed that the bones recovered from Feature 2 had been incorrectly identified as faunal remains and were instead human; with this discovery, Feature 2 was determined to be a burial (labeled Burial 1). This raised several questions that needed to be answered as part of reevaluating the site's National Register and State Archeological Landmark eligibility. First, were more bones associated with those in Burial 1 present just outside the block excavation (Burial 1 was only $22 \mathrm{~cm}$ from the edge of the block), and did these remains represent a disturbed human burial, or did Burial 1 represent a bundle burial consisting solely of leg bones? Second, were there other features with human remains present, indicating that 41BU51 was used as a cemetery? If $41 \mathrm{BU} 51$ did contain additional burials with preserved human remains, then it would have the capacity to yield important information, and it would be considered eligible for National Register listing under Criterion D and designation as a State Archeological Landmark. A second phase of testing was planned to answer these questions.

\section{SECOND PHASE OF TESTING}

The second phase of test excavations was performed in January 2004, under Contract No. 573XXSA001, Work Authorization 57312SA001, and Texas Antiquities Permit No. 3030 (McWilliams et al. 2004). The work authorization called for re-locating the backfilled block excavation from initial testing, using heavy equipment to strip the sediments around the block to search for human remains, and, if human remains were found, map them and cover them back up so that they would be preserved and protected until consultation was completed and a plan of action formulated.

\section{Work Accomplished}

The work began with re-locating the 2003 block excavation using landmarks mapped with the total station (TDS) during the first phase of testing. Using TDS data from the 2003 excavations and two known points along the fence line at the western edge of the site, the location of Burial 1 was reestablished. A 10x10-m block was then measured out, with the former location of Burial 1 at the center. Elevation control also was reestablished using the TDS data. The surface 
of the site had been modified since the 2003 excavations. The area had been backfilled, and runoff had occurred, so the surface elevation was reassessed. It was determined that there had been only minimal changes in surface elevation (2-4 cm increase from 2003 to 2004).

In addition to the Gradall operator, a crew of four archeologists, two of whom had training in identifying human skeletal materials, performed the excavations. One crewmember had training in TDS mapping. Two archeologists examined areas as they were being stripped, and two monitored backdirt as it was being emptied from the Gradall bucket, thoroughly troweling through backdirt and inspecting it for bones and other cultural materials.

A Gradall stripped most of the sediments around the block to search for human remains and cultural features, with a backhoe being used for the task on the first day, when the Gradall was not available. The block was excavated in levels no more than $10 \mathrm{~cm}$ thick to a depth of ca. $80 \mathrm{~cm}$ (Burial 1 was at ca. 105-115 cm below the surface). Below $80 \mathrm{~cm}$ to the base of the Holocene sands, where additional remains associated with Burial 1 were considered most likely, stripping was done in slices as thin as the Gradall could manage, sometimes $5 \mathrm{~cm}$ or less. The TDS was used to monitor the depth of excavations throughout the course of the work. Shovel-skimming and troweling were used periodically to investigate stains and artifacts and to ensure that no human remains and cultural features were missed.

The scope of work called for an initial 100$\mathrm{m}^{2}$ block (Main Block; Figure 2.3) to be excavated centered on the former location of Burial 1, with at least an additional $5 \mathrm{~m}$ cleared in all directions from any identified human remains. Excavation in the initial $10 \times 10-\mathrm{m}$ block proceeded east to west and south to north (Figure 2.4). Three additional burials (Burials 2 through 4 ) and two isolated probable human bones (Isolated Bones 1 and 2) were found in this initial block. Upon completion of the Main Block, additional areas around it-termed South Block, West Block, West Block Extension, North Block, and East Block-were opened up to make sure that no other human remains were present. One isolated probably nonhuman bone (Isolated Bone 3; see Chapter 3) was found in the West Block. Combined, these machine-excavated areas encompassed $333 \mathrm{~m}^{2}$.
Artifacts collected during the stripping were limited. Only 19 diagnostic items, mostly dart points, were collected and returned to the laboratory for analysis. These materials were mapped with a TDS when they were identified in situ; when they were found in backdirt, their approximate provenience was mapped with the TDS. These artifacts were collected becausealong with the diagnostic items and radiocarbon dates obtained during the initial testing - they can contribute to defining the chronology of $\mathrm{Na}$ tive American use of the site.

When bones were exposed, stripping ceased in that area, and sufficient cleaning with shovels, trowels, and brushes was done to determine the nature of the remains. When the remains were determined to be human, they were exposed only to the extent needed to ascertain the parts of the skeleton present and their orientation. The bones were recorded using the standard osteological inventory form and coding system available in Standards for Data Collection from Human Skeletal Remains (Buikstra and Ubelaker 1994).

Demographic, pathological, and other types of analytical osteological data were almost invariably unavailable because of several factors, including the incompleteness and sometimes poor condition of the remains as well as the fact that most elements were not completely exposed in situ, disallowing most observations. Where available, such information was recorded by handwritten notes rather than by use of standard forms. Drawings and color and black-and-white photographs were also made, and the locations of remains were mapped using a TDS. Human remains found were left in situ and marked with rebar (usually two pieces marking edges of the deposits) and covered with cotton sheeting; at least $20 \mathrm{~cm}$ of yellow sand was placed manually on top of the sheeting to protect the bones, and plywood was placed on top of the sand fill. The yellow sand, excavated from very deep deposits underlying the clay and noticeably different from the homogenous brown sand that covers most of the site, was used to more clearly indicate burials for re-location. Human remains were covered in this way on the same day they were found. At the completion of the work week and at the end of the project, additional fill was placed on top of the plywood to backfill the excavations. 


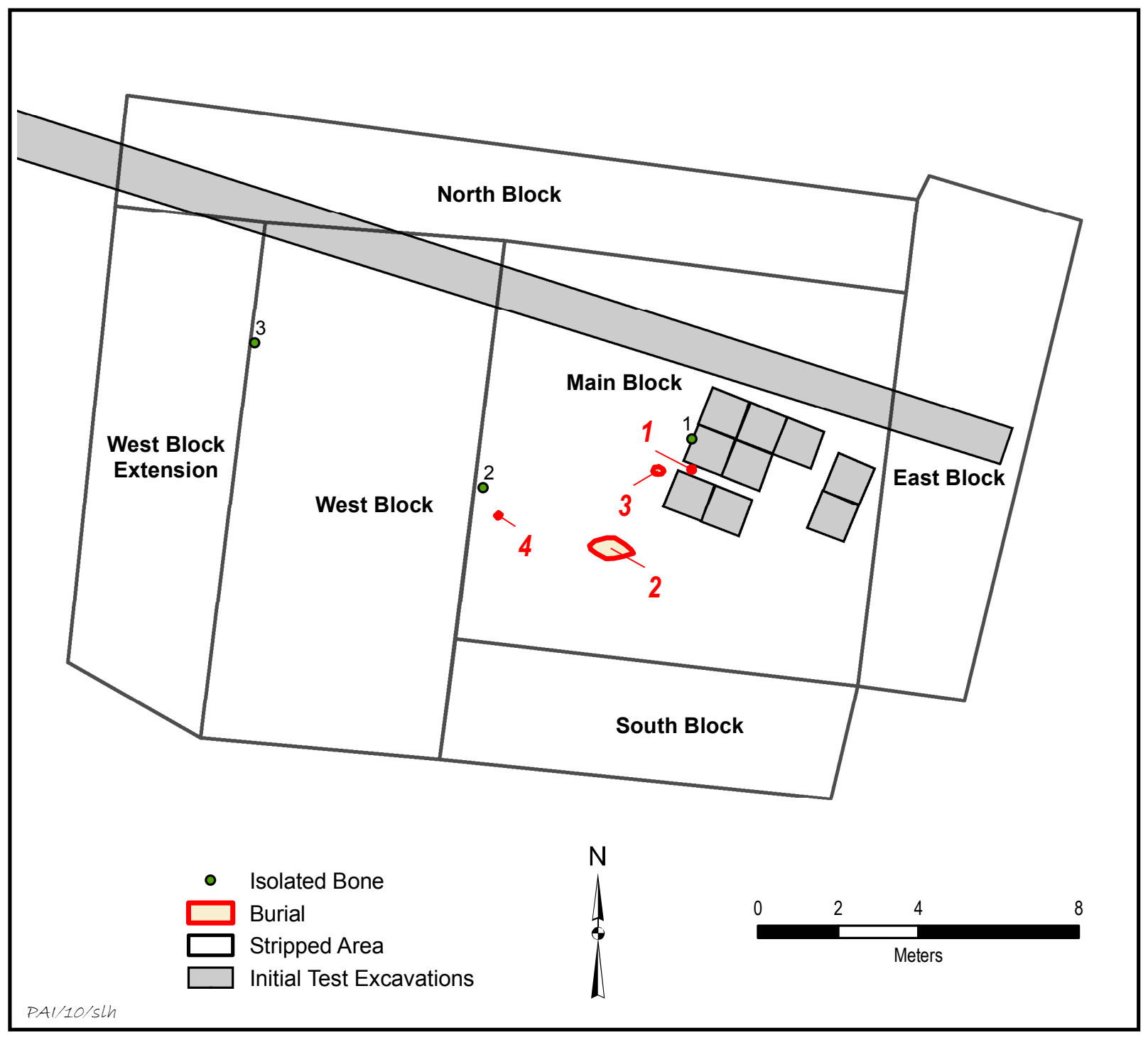

Figure 2.3. Plan of area excavated in the second phase of testing, showing locations of Burials 1-4 and Isolated Bones 1-3.

\section{Features}

As noted, three additional human burials were identified in the $333-\mathrm{m}^{2}$ area excavated by the Gradall, along with three isolated bones, two of which were human and one of which was not (see Chapter 3 for descriptions). All of the human remains were located within $5.5 \mathrm{~m}$ of Burial 1 found during initial testing. Burial 2 was $2.1 \mathrm{~m}$ southwest of Burial 1, Burial 3 was $0.7 \mathrm{~m}$ west of it, and Burial 4 was $5 \mathrm{~m}$ west-southwest of it. Isolated Bone 1 (human) was $0.8 \mathrm{~m}$ west of Burial 1, and Isolated Bone 2 (human) was just northwest of Burial 4. Isolated Bone 3 (nonhuman) was on the west side of the excavation, $7.3 \mathrm{~m}$ from the nearest grave (Burial 4). These features and osteological remains are described in Chapter 3.

Feature 3 was also identified and investigated during this phase of testing. It was located along the eastern edge of the southeast portion of the Main Block at an elevation of 101.002$101.116 \mathrm{~m}$. Described as a half-circle of compact and slightly gravelly sediment measuring $2 \mathrm{~m}$ (east-west) by $1 \mathrm{~m}$ (north-south), Feature 3 continued south of the south wall of the initial 
10x10-m block. Shovel probing suggested that it was a thin veneer of paleosol resting on the basal clay. Because it was deemed to be noncultural in origin, this feature is not discussed further in this report.

\section{Artifacts}

Artifacts observed during the stripping include many flakes, several tested cobbles, cores, bifaces, burned clay nodules (many large), charcoal, silicified wood fragments, and burned rocks (primarily river cobbles). Nondiagnostic artifacts were observed primarily in the upper sand deposits. Very few artifacts of any kind were observed in the dark brown paleosol or strong brown clay subsoil.

Diagnostic artifacts collected include 17 projectile points (11 of which are complete or nearly complete) and 6 ceramic sherds. Projectile points were recovered at depths ranging from 2 to $187 \mathrm{~cm}$. Sherds were recovered from 80 to $139 \mathrm{~cm}$. These artifacts are described in Chapter 4.

\section{Revised Site Assessment}

The second phase of testing revealed that 41BU51 contained a small prehistoric cemetery with four interments probably dating to the latter part of the Late Archaic period or the early part of the Late Prehistoric period, judging from the kinds of artifacts found in the surrounding sediments. Based on this, the site was reassessed as containing important information and hence as being eligible for listing in the National Register of Historic Places and designation as a State Archeological Landmark. Although the state of preservation was not optimal, these human remains were considered to have the capacity to contribute important information about the health and diet of the Native American groups

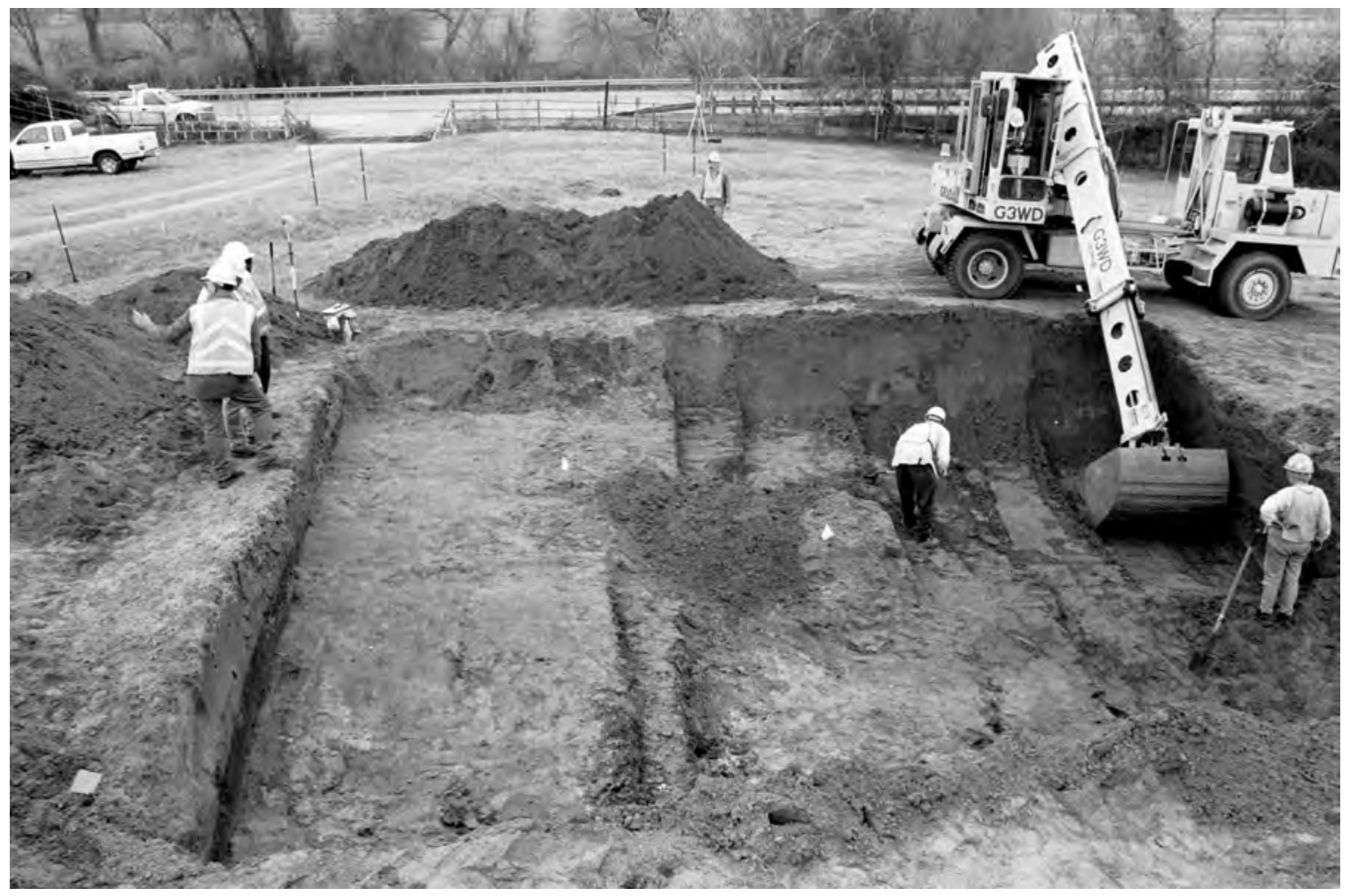

Figure 2.4. Photograph of Gradall excavation in progress; view is to the west with FM 60 in the background. 
who lived in this part of the Brazos River valley. As a result, data recovery excavations were recommended.

\section{DATA RECOVERY EXCAVATIONS}

Data recovery excavations, consisting solely of removal of Burials 2-4 and Isolated Bones 1-3, took place in June 2007 under Contract No. 577XXSA001, Work Authorization 57715SA001, and Texas Antiquities Permit No. 4546. The excavations were preceded by preparation of a research design and data recovery plan that sought to maximize the information gained through analysis of the remains.

\section{Research Design}

The research design recognized that the important information that 41BU51 contains relates to the human remains buried there and what they could reveal about the health, diet, and lifeways of the Native American groups who lived in this area, especially if that information could be viewed within a context encompassing other known prehistoric human remains in the region. At the time the research design was prepared, little could be said about the health, diet, and lifeways of Native Americans who lived in the area of 41BU51 because very few archeological projects yielding data relevant to these topics had been undertaken in the area. Some excavations had been done by avocational archeologists at important sites, such as 41BU17 (Bowman 1985), but it is hard to use the reported data for interpretive and comparative purposes. Other sites, such as 41BU16 (Roemer and Carlson 1987), had been excavated professionally but have limitations because of problems with contextual integrity. Other projects had resulted in valuable information on certain topics, for example, site formation processes (Thoms 1993), but did not yield other kinds of substantive information because they were survey or limited testing projects.

The capacity of the data from 41BU51 to constitute important information was heightened by the fact that this site and several others nearby contain small cemeteries or isolated human graves dating to the Late Archaic or early Late Prehistoric periods, apparently representing conspicuous use of sites in this part of the Brazos River valley for mortuary activities at a time when other important cultural changes were taking place, as highlighted by Shafer's (2006) recent suggestion that people of the Blackland Prairie and Oak Woodlands were intimately linked with Caddo peoples farther east by the early part of the Late Prehistoric period.

The capacity for the burials from 41BU51 to address some topics was understood to be limited because of their incompleteness and the generally poor condition of the bones present. Because of the poorly preserved postcrania, the potential for insights into detailed demographics, markers of physical activity and stress, and certain classes of pathology was considered low. Analysis of the teeth was recognized to have perhaps the highest potential, as teeth have a high probability of preservation and can provide indications of dietary content and oral health, early childhood development, and possibly genetic relationships. The possibility of trauma or "trophy-taking" evidence on the isolated crania was also recognized.

Despite the potential limitations to the research agenda imposed by the remains themselves, comprehensive macroscopic analyses, including inventory, age and sex, pathologies, nonmetric traits, and metrics, were planned to allow for maximum data recovery. The use of the forms and coding procedures provided in Standards for Data Collection from Human Remains (Buikstra and Ubelaker 1994) was proposed for the bulk of the analysis, with the more-detailed ASU classification system described in Scott and Turner (1997) and Turner et al. (1991) to be used to score dental nonmetric traits. In addition, it was proposed that appropriate samples of bone be taken from each burial and submitted for radiocarbon dating and to derive stable carbon and nitrogen isotope $\left({ }^{13} \mathrm{C} /{ }^{12} \mathrm{C}\right.$ and $\left.{ }^{15} \mathrm{~N} /{ }^{14} \mathrm{~N}\right)$ ratios, which might help reconstruct diet, including $\mathrm{C}_{4}$ vs. $\mathrm{C}_{3}$ plant, meat and fish, and legume consumption.

To increase the interpretive potential of the analysis of the 41BU51 burials, comparison and synthesis of mortuary and bioarcheological data from additional sites was proposed, starting with sites nearby within the Brazos River valley. To this end, two additional tasks beyond study of the 41BU51 burials were proposed. First, reanalysis of skeletons, if available, from 41BU16 and $41 \mathrm{BU} 17$ was to be performed, with this study to include other regionally relevant hu- 
man remains held by the Texas A\&M University Anthropology Laboratory and the Brazos Valley Museum of Natural History. Where available, all such remains were to be analyzed using the same procedures followed for the 41BU51 burials, including radiocarbon dating and stable isotope analyses. Second, published data on human remains and mortuary practices, as well as site function, at contemporaneous sites in this part of Texas were to be examined and, if relevant, used for comparative study.

The research design also specified completion of analysis and reporting of the nonburial occupational debris collected in testing 41BU51 in 2003 and 2004. While most of these remains are of limited interpretive value because of the inability to isolate discrete components, basic description and quantification of the collection needed to be finished beyond what was reported in the interim reports on the two testing phases.

\section{Work Accomplished}

Fieldwork began with re-locating the three burials and three isolated bones using landmarks mapped with the TDS during the second phase of testing. Beginning ca. $5 \mathrm{~m}$ north of the northernmost feature, Isolated Bone 1, a Gradall was used to remove the overburden from above the features. Stripping was done in slices no more than $10 \mathrm{~cm}$ thick from the surface while monitored by archeologists. Burials 2-4 and Isolated Bone 1 were exposed first in a single excavation. Machine excavation was stopped when the rebar stakes around each feature were exposed. Isolated Bone 2 was exposed entirely by hand excavation. A separate machine-excavated block exposed Isolated Bone 3.

The remaining overburden above the plywood used to cover the burials and isolated bones during the second phase of testing was removed by shovel by the archeologists. After

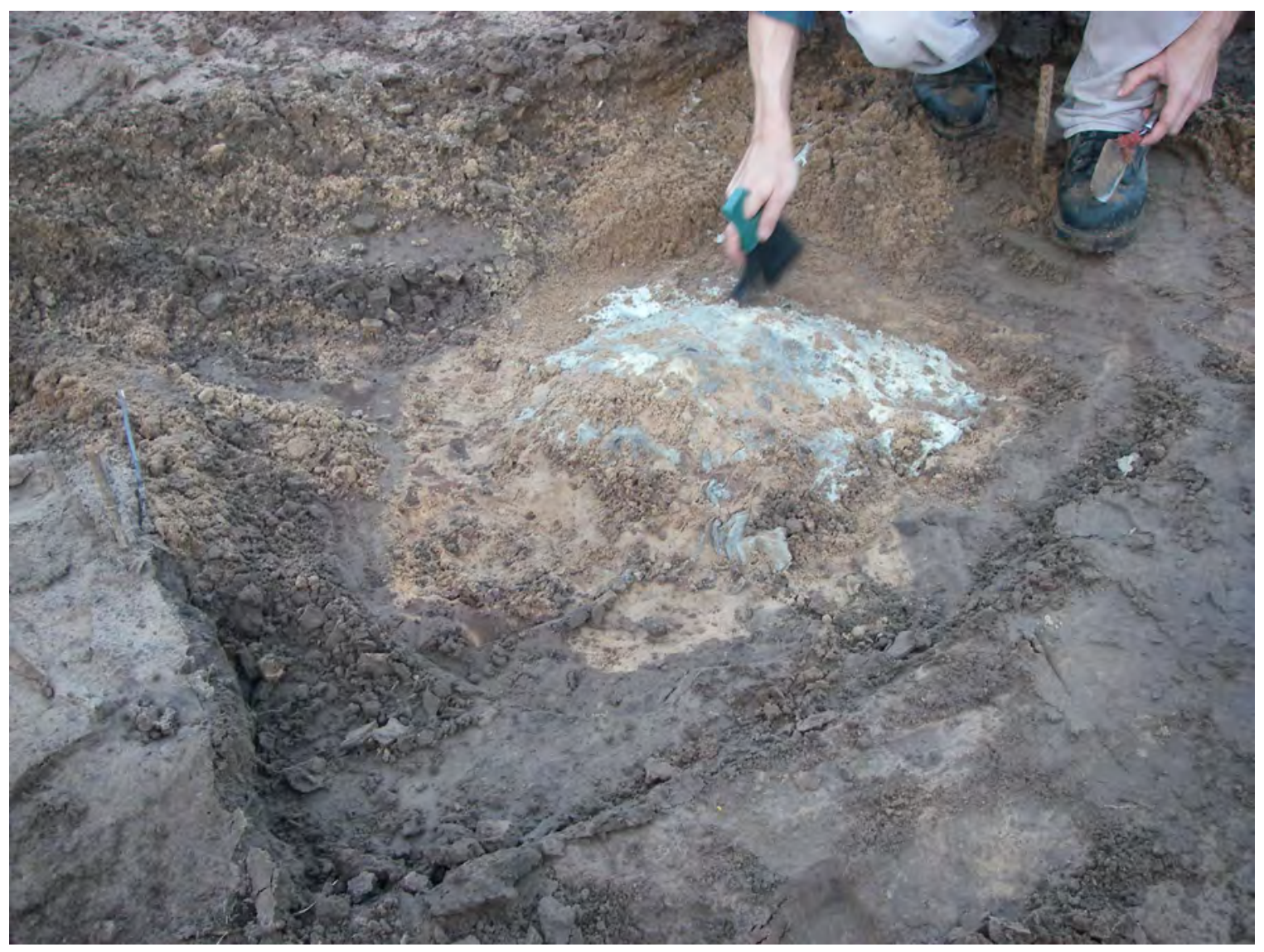

Figure 2.5. Re-exposure of Burial 2; note sheet and yellow sand used to mark the burial during the second phase of testing for later removal. 
the plywood was removed, the sheet and fill sand placed above each burial and isolated bone were removed using trowels and soft brushes (Figure 2.5). The bones were then exposed using bamboo implements and soft brushes. For Burials 2-4, samples of the matrix surrounding the bones were taken, and the remaining matrix was screened through 1/4-inch-mesh hardware cloth. For Isolated Bones 1-3,no fill samples were taken and no matrix screening was performed. Details such as elevation, matrix/fill description, disposition, disturbances, and overall condition were recorded for each burial on a standardized feature form, and each was drawn using the TDS-mapped rebar stakes as reference points. Digital photographs also were made. When necessary, osteological inventory or analysis was performed before removal of skeletal elements. Excavated bones were placed individually in aluminum foil for protection. The remains recovered in this phase of work are described in Chapter 3.

Unfortunately, some of the analyses proposed in the research design could not be completed as planned, and hence the project produced less useful information than it might have. These limitations were caused by the following: permission to perform radiocarbon dating and isotopic studies on the human remains from 41BU51 could not be obtained; and human remains from other nearby sites could not be secured for comparative analysis. The search for human remains from other nearby sites revealed that Texas A\&M University does have materials from two sites (41BU16 and 41BU52), but because of NAGPRA-related issues, permission to do certain kinds of analyses could not be granted. One of the more-important comparative samples, excavated from the Winnie's Mound site (41BU17) by avocational archeologist Bradley Bowman, apparently was reburied on the site and is not available for reanalysis. Bowman also has limited skeletal remains from the Foster site (41MM13), near the confluence of the Brazos and Little Rivers (Bowman 2008), but efforts to secure these remains for inclusion in this study were abandoned when no other comparative samples could be obtained. Finally, the Brazos Valley Museum of Natural History has several sets of human remains in its collection (one skull [accession \#23.90]; ribs and vertebral fragments [30.90]; ribs and vertebral fragments [75.90]; and a skull, mandible, and few vertebral fragments [31.90]) that could have been collected from one or more sites in the region, but provenience information is scanty. Because it is uncertain where they came from, including them in a comparative study was considered unwise. 



\section{CULTURAL FEATURES AND DESCRIPTION OF OSTEOLOGICAL REMAINS}

\section{3}

The excavations at 41BU51 resulted in the identification of a maximum of four burials (Burials 1 through 4) and three isolated bones (Isolated Bones 1 through 3). Isolated Bones 1 and 2 are human and may have been displaced from nearby burials; Isolated Bone 3 appears not to be human. Each of the burials was also assigned a feature number (Nos. 2, 4, 5, and 6), but the isolated bones were not. As described in Chapter 2, Features 1 and 3 were determined to be noncultural in origin and are not described here. The burials are the only cultural features of any type recorded during all three phases of work. Burial 1 was excavated during the first phase of testing, and Burials 2 through 4 and all three isolated bones were identified during the second phase of testing and excavated during data recovery. Burials were defined as interments consisting of multiple elements or isolated crania. Isolated bones were defined as individual elements of the postcranial skeleton unassociated with any other human bones.

The four burials and two isolated human bones were clustered in a ca. $6 \times 3-\mathrm{m}$ area in the western half of the 10x10-m Main Block (Figure 3.1). Based on physical proximity and the fact that elements are not duplicated, Burials 1 and 3 and Isolated Bone 1 actually could represent a single interment, as could Burial 4 and Isolated Bone 2. Hence, the minimum number of individuals represented is three. The maximum is six. None of the burials were accompanied by artifacts interpreted as grave offerings, although some apparently unassociated artifacts were found in the surrounding matrix.

Where applicable, archeological data reported here include approximate burial depth, body position, and bone/body orientation. Approximate depth is presented here for all remains as below the ground surface at Test Unit 8, the horizontal provenience of Burial 1.
Osteological analysis generally followed the procedures and scoring outlined in Buikstra and Ubelaker (1994). The Arizona State University Dental Anthropology System (Scott and Turner 1997; Turner et al. 1991) was utilized for recording dental nonmetric traits. Osteological data provided here includes a skeletal inventory, taphonomic information, demographic and pathologic information, a dental inventory, and descriptions of dental wear, pathologies, and nonmetric traits.

\section{BURIAL 1 (FEATURE 2)}

Burial Description: Recovered during the first phase of testing, the skeletal remains consist of the leg bones from a single individual (Figure 3.2). The remains were found at the south edge of Test Unit 8 and in the 30 -cm-wide balk between that unit and Test Unit 9, at a depth of 92-104 $\mathrm{cm}$ below the ground surface (arbitrary absolute elevation of 100.43-100.55 m). Most of the bones were clustered in a $23 \times 24-\mathrm{cm}$ area, although one fragment was found $14 \mathrm{~cm}$ south of this cluster. No grave pit could be discerned, and the surrounding sediments were the same dark yellowish brown sands that occur toward the bottom of the sand mantle across the site.

Position and Orientation: The right femur and left tibia/unsided fibula were lying on either side of and parallel to a tight cluster of bones consisting of the left femur, right tibia, and another unsided fibula. These bones were oriented northwest-southeast. The talus was found ca. $14 \mathrm{~cm}$ south of the other bones. Not enough data are available to definitively ascertain whether this is the remnant of a tightly flexed burial or a bundle burial, although the latter seems more likely based on the arrangement of the bones. The distal end of the right femur and the proximal end of the left tibia appear to point 


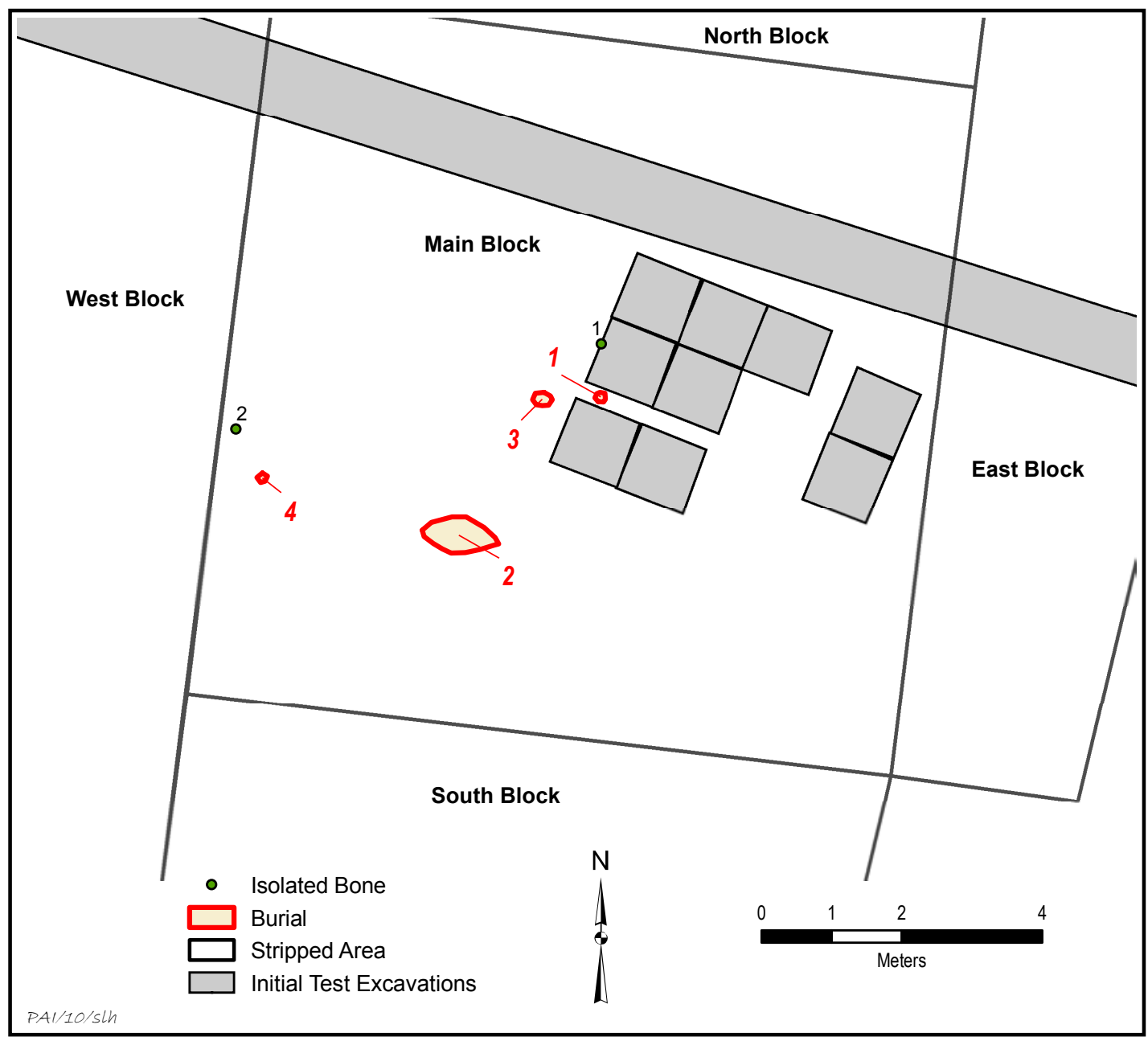

Figure 3.1. Plan showing the locations of Burials $1-4$ and Isolated Bones 1 and 2.

northwest, but the directions of the other bones are unknown.

Associations: Isolated Bone 1, a humerus fragment, was found about $0.8 \mathrm{~m}$ north of and $22 \mathrm{~cm}$ lower than Burial 1. Their overall conditions are similar. Burial 3, an isolated cranium, was $0.7 \mathrm{~m}$ to the west and at a similar elevation as Burial 1 (100.42-100.62 m). All of these remains could represent a single individual. Twelve pieces of debitage and a core were recovered from the sediments around the bones. Because these artifacts are no different than the cultural materials that occur throughout the lower sands at 41BU51 and they did not appear to be arranged in any particular way relative to the bones, they are interpreted as incidental inclusions rather than grave offerings.

Osteological Inventory: Skeletal remains consist of partial diaphyses of the right and left femora, right and left tibiae, and right and left fibulae, as well as a fragment of the left talus (Appendix B). The bones are fragmented and their cortices are deteriorated. Rodent gnawing is common. No measurements could be made on the bones due to their condition and a lack of landmarks.

Age and Sex: The size and moderate robusticity of the bones are consistent with those 


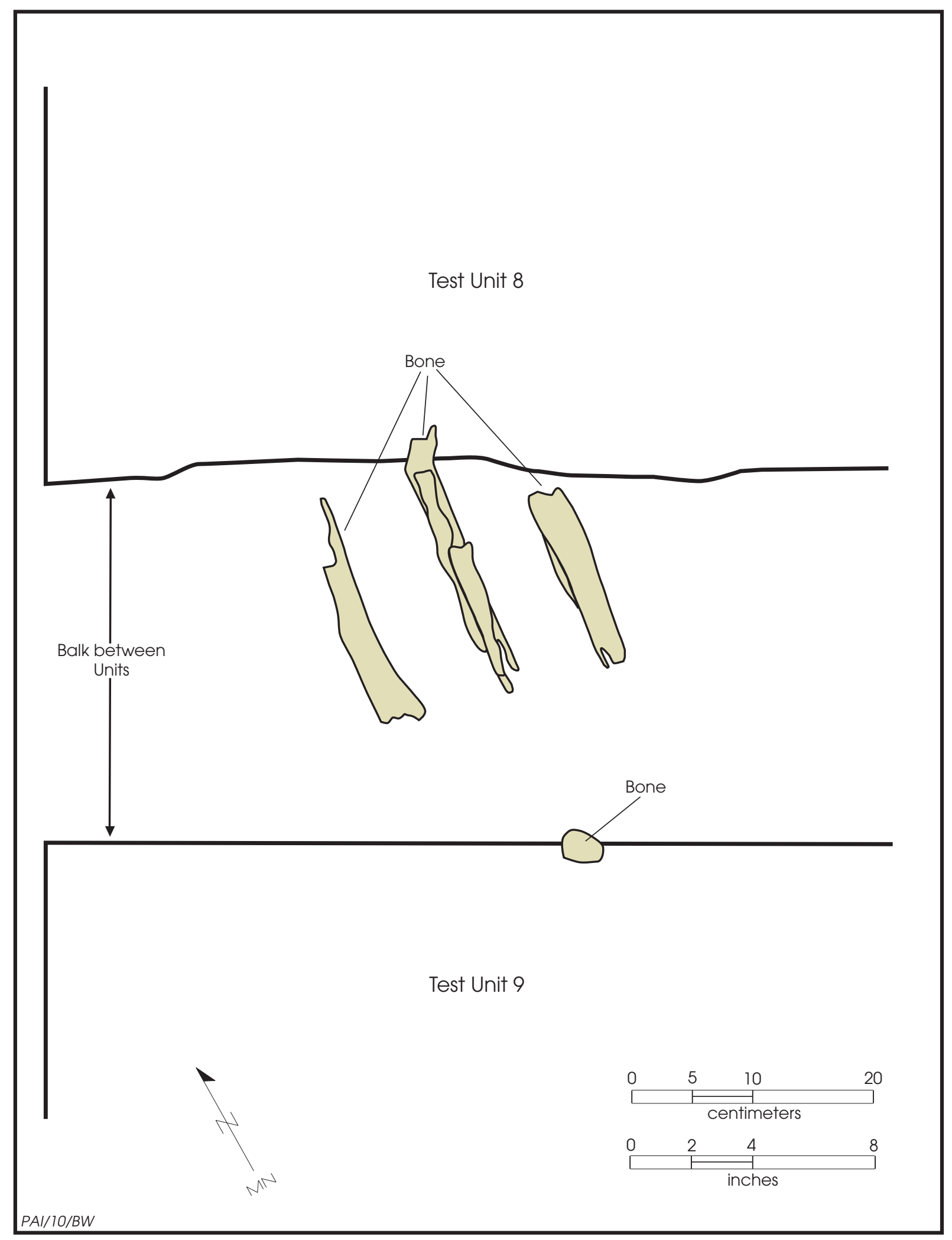

Figure 3.2. Plan view of Burial 1. 
found in an adult, but no specific age indicators are present. No indicators of the sex of the individual are present.

Skeletal Pathology: No pathology was observed.

Dental Inventory: No teeth are present.

Dental Wear: NA

Dental Pathology: NA

Dental Nonmetrics: NA

\section{BURIAL 2 (FEATURE 4)}

Burial Description: Burial 2 was originally identified as the cranium and at least partial postcranial remains of an individual interred in an oval pit measuring approximately $1.14 \mathrm{~m}$ east-west and $0.52 \mathrm{~m}$ north-south (Figure 3.3). Only enough of the burial was exposed to confirm that it was human. Frontal, parietal, and occipital bones were identified. A single long bone diaphysis, either a femur or humerus, was also recorded. Data recovery excavations largely confirmed the observations made during the testing phase and revealed additional postcranial elements. The burial is in the south-central part of the Main Block, ca. $2.1 \mathrm{~m}$ southwest of Burial 1. The pit was encountered first at an elevation of $100.71 \mathrm{~m}$, with the uppermost bones at $100.63 \mathrm{~m}$ and the lowermost ones at $100.53 \mathrm{~m}$. In plan, the gray sandy pit fill contrasted with the surrounding reddish brown sandy sediments. Reddish brown clayey sediments were encountered beneath the north half of the pit, but the bottom of the south half was indistinct. No bones were present in the south half, suggesting that this part of the grave had been disturbed.

Position and Orientation: The head is at the west end of the pit, with the top of the cranium presumably pointing west, and the postcranial remains are oriented east-west to the east of the cranium. The long bones are tightly packed at the north end of the pit. The distal ends of the femora point west, and the proximal ends of the tibiae point east and are in close approximation, suggesting they are in articulation. The distal end of the humerus points east, which would be expected if it was in articulation with the rest of the body. The orientation of the bones suggests the individual was lying on the left side, tightly flexed, the knees drawn up to the chest, and the legs and lower legs parallel with one another and with the upper arms. Nonetheless, it is possible that this is a bundle burial rather than a flexed burial.

Associations: A Bulverde dart point was recovered $15 \mathrm{~cm}$ north-northwest of the burial's head and at the same elevation as the uppermost bones, but it was outside the burial pit and is not likely associated. Three burned clay nodules, three burned rocks, and 12 flakes were recovered from the fill of the pit. Because these artifacts are no different than the cultural materials that occur throughout the lower sands at the site and they did not appear to be arranged in any particular way within the feature, they are interpreted as incidental inclusions not directly associated with the burial.

Osteological Inventory: Due to their poor condition, the bones of the cranium could not be positively identified. In-field observations suggest occipital fragments were recovered. Portions of the diaphyses of the right and left femora, tibiae, and fibulae are present, as is an unsided humerus (see Appendix B). The proximal end of a metatarsal, possibly a first, is also present. Several possible ribs were observed in situ but could not be recovered due to poor condition. This burial was in the poorest condition of the four at the site. The cranium was mostly incomplete and brittle, crushed, and fragmented in situ. The long bones also were very brittle, crushed, and fragmented, held together by the surrounding matrix. Even in situ, the fibulae consisted only of bone dust indicating its position. There is minor rodent gnawing on many of the long bones. No measurements were possible due to the poor condition of the bones.

Age and Sex: The size and robusticity of the long bones and cranium suggest an adult, but no specific age indicators are present. The linea asperae and gluteal tuberosities on the femorae are well developed, although overall the bones are somewhat gracile. The nuchal crest is very gracile and suggests a female (score of 1 using Ascádi and Nemeskéri [1970] in Buikstra and Ubelaker [1994]). However, in addition to the problems inherent with using a single marker to assess sex, the gracility of the population in this region overall has been noted (D. Gentry Steele, personal communication to Bradley Bowman, December 16, 1986, reported in Bowman 2008:230]), so these markers may not be very informative for differentiating the sexes. No other morphologic features suggestive of sex are present. 


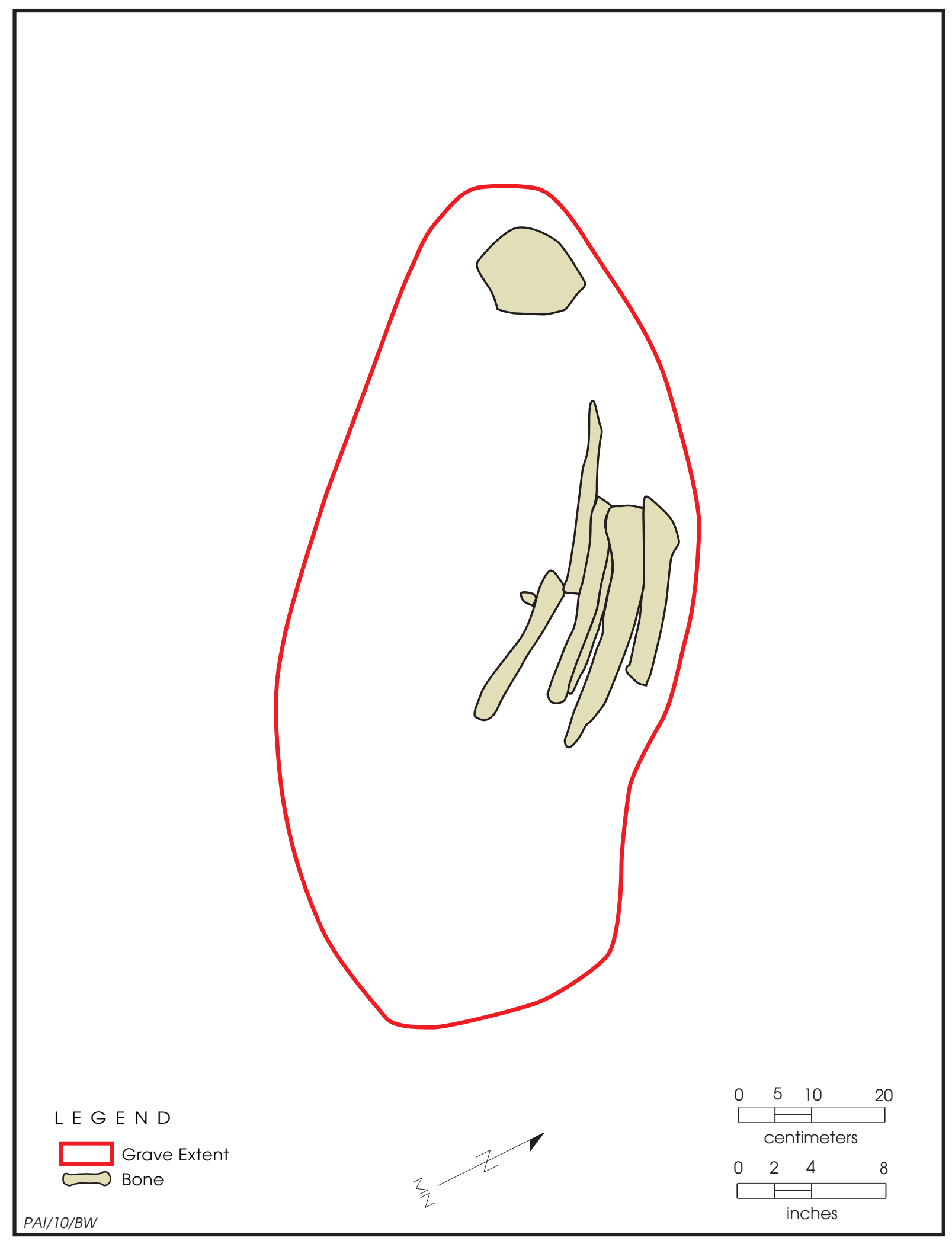

Figure 3.3. Plan view of Burial 2. 
Skeletal Pathology: The 15-cm-long fragment of the right tibia shows widespread but inactive and well-incorporated compact bone proliferation across the medial and lateral compartments, evidence of a well-healed infection or inflammation of the periosteum.

Dental Inventory: No teeth are present.

Dental Wear: NA

Dental Pathology: NA

Dental Nonmetrics: NA

\section{BURIAL 3 (FEATURE 5)}

Burial Description: Burial 3 was originally identified as an isolated cranium of an adult in the central part of the Main Block, ca. $0.7 \mathrm{~m}$ west of Burial 1 at an elevation of 100.42-100.62 m. No grave pit could be discerned, and the surrounding sediments were the same dark yellowish brown sands that occur toward the bottom of the sand mantle across the site. The bone was partially fragmented by the Gradall during testing, with many of the fragments recovered by screening the backdirt, but much of it remained in situ over an area of $20 \times 17 \mathrm{~cm}$. Overall, the bone seemed to be in good condition. Data recovery excavation showed this individual is represented by a largely complete calvarium and an articulated mandible.

Position and Orientation: The cranium is lying on its left side, facing north, with the top of the head pointing roughly west.

Associations: Three burned clay nodules and 13 flakes were recovered from the matrix surrounding the skull. Because these are no different than the cultural materials that occur throughout the lower sands at the site and they did not appear to be arranged in any particular way relative to the cranium, they are interpreted as incidental inclusions not associated with the skull. Isolated Bone 1, a humerus fragment, was found about $1.0 \mathrm{~m}$ to the northeast of and $21 \mathrm{~cm}$ lower than Burial 3, and Burial 1 was $0.7 \mathrm{~m}$ to the east and at a similar elevation $(100.43-100.55 \mathrm{~m})$. All of these remains could represent a single individual, although this is not clearly the case.

Osteological Inventory: The frontal (except the region around the supraorbital tori and the orbits), right and left parietals, right and left temporals (all except the bases of the mastoid processes have been eroded away), and occipital (except most of the bone around the foramen magnum) are present (see Appendix B). A portion of the mandible encompassing the anterior and right posterior dentition also was recovered, although much of the corpus of the bone is gone. Overall, the cranium is fragmented. During testing, the Gradall scraped through much of its right half, although most of these fragments were recovered from the backdirt. The outer table of the cranium has been gnawed by rodents and shows significant erosion, with some penetration through the bone. Otherwise, the pieces are solid. Due to the fragmentation and the fact that the calvarium would be incomplete even with reconstruction, no measurements were attempted.

Age and Sex: The external (anterior sagittal, bregma, and midcoronal) and internal (sagittal and left coronal) cranial vault sutures that could be assessed are completely closed (score 3). Although these data are incomplete, they suggest an age of at least 40 years at death (Meindl and Lovejoy 1985). The heavy attrition on the teeth also suggests an individual of advanced age, although dental aging standards for this population have not been proposed. The nuchal crest is very gracile (score 1 using Ascádi and Nemeskéri [1970] in Buikstra and Ubelaker [1994]), and the supramastoid crest is unmarked and does not extend beyond the external auditory meatus. Overall, these features suggest a female, although as noted above, caution should be used in their interpretation.

Skeletal Pathology: On the left side of the frontal, approximately $1 \mathrm{~cm}$ posterior to the temporal line and superior to the upper margin of the eye orbit, there is a $0.59-\mathrm{cm}$-diameter and up to $0.40-\mathrm{cm}$-deep circular hole. It is oriented posterior to anterior, rather than perpendicular to the bone, so that the anterior part of the hole is covered with bone. It does not penetrate through the inner table. Its margins are eroded and could not be assessed. There is no hint of fracturing or trauma. The cancellous bone does not show evidence of active bone proliferation or resorption. This seems more likely the result of a taphonomic process rather than a physiologic one. However, a taphonomic process could have built on a defect already present at the time of death.

Dental Inventory: No maxillary teeth are present. Mandibular teeth (complete) present are: $\mathrm{RP}_{1} ; \mathrm{RP}_{2} ; \mathrm{RM}_{2}$; and unidentified incisor. Roots of $\mathrm{LI}_{2}, \mathrm{LC}, \mathrm{LP}_{2}, \mathrm{LP}_{2}, \mathrm{RC}$, and an LM are 
also present. Two unidentified root fragments also are present. The teeth are very fragile and fragmentary.

Dental Wear: The enamel of all teeth whose crowns are at least partially intact and observable $\left(\mathrm{RP}_{1} ; \mathrm{RP}_{2} ; \mathrm{RM}_{2}\right.$; and unidentified incisor $)$ has been worn down to the root, and secondary dentin deposition is present. A small rim of enamel is still present at the cemento-enamel junction on each of these teeth. On the premolars, it is present on the buccal side, and on $\mathrm{M}_{2}$ it is present on the lingual side. Wear score is 7 to 8 on the incisor and premolars (Smith 1984) and 9 to 10 on the molars (Scott 1979).

Dental Pathology: There is a loss of alveolar bone height around $\mathrm{RM}_{2}$ suggestive of periodontal disease, but damage and erosion make this difficult to interpret. $\mathrm{RM}_{3}$ appears to have been lost antemortem. $\mathrm{RM}_{1}$ was lost antemortem subsequent to a dental abscess. The entire buccal side of the alveolar bone of the crypt has been resorbed. There is no evidence of infection or active bone resorption at the site, suggesting the tooth was lost well before death. None of the teeth have pulp chamber exposure, despite their heavy wear. All roots that are observable (unidentified incisor; $\mathrm{LP}_{2}$; LM; and two unidentified fragments) exhibit hypercementosis.

Dental Nonmetrics: Not observable.

\section{BURIAL 4 (FEATURE 6)}

Burial Description: Burial 4 was originally identified as an isolated cranium of an adult in the western part of the Main Block at an elevation of $100.57 \mathrm{~m}$. The bone was fragmented by the Gradall during testing, with many of the fragments recovered by screening the backdirt, but much of it was thought to remain in situ. Data recovery excavation found only a single, very friable piece of cranial bone in an area of about $7 \times 7 \mathrm{~cm}$ in situ as well as the fragments recovered from the Gradall backdirt, which had been wrapped in cloth and placed on top of the in situ cranium. No grave pit could be discerned, and the surrounding sediments were the same dark yellowish brown sands that occur toward the bottom of the sand mantle across the site.

Position and Orientation: Not enough of the cranium remained to draw any conclusions regarding its position or orientation.

Associations: Isolated Bone 2, a femur, was found $1.0 \mathrm{~m}$ northwest of the cranium at essentially the same elevation $(100.58 \mathrm{~m})$ and could be associated. No artifacts were found in the surrounding matrix.

Osteological Inventory: Osteological remains consist of $60+$ fragments $(68.6 \mathrm{~g})$ of the parietals and the occipital (see Appendix B). Less than 25 percent of each of these bones is present. The largest fragment is ca. $4.5 \mathrm{~cm}$, and most are $2 \mathrm{~cm}$ or less. The outer table of bone is porous, rough, and weathered.

Age and Sex: In-field observations during testing suggested the overall size of the cranium was consistent with an adult. A short (ca. $2 \mathrm{~cm}$ ) length of the coronal, sagittal, or lambdoidal suture shows between minimal and significant closure, suggesting an age range of ca. 35 to 45 years old at death, with standard deviations from 8 to 12 years (Meindl and Lovejoy 1985:61, Table 3). This could not be confirmed upon recovery of the remains because of fragmentation. Although up to 2-cm lengths of sagittal and other unidentified sutures were observed, their closure could not be assessed due to breakage along the suture line. The nuchal crest is very gracile (score 1 using Ascádi and Nemeskéri [1970] in Buikstra and Ubelaker [1994]), suggesting female, although as noted above, caution should be used in interpreting this. No other morphologic features suggestive of sex are present.

Skeletal Pathology: Not observable.

Dental Inventory: No teeth are present.

Dental Wear: NA

Dental Pathology: NA

Dental Nonmetrics: NA

\section{ISOLATED BONE 1}

Description: Isolated Bone 1 is a 5.12-cmlong section $(3.4 \mathrm{~g})$ of the anterior portion of a human humerus. It appears to be from the distal third of the diaphysis. No landmarks are present, and its side is indeterminate. The cortical surface shows significant rodent gnawing. There is no information regarding its position or orientation in situ.

Age/Sex/Pathology: The overall size and robusticity of the bone are consistent with an adult. No other indicators of age or sex were observed. No measurements were possible due to the bone's incompleteness and small size. No pathology is present.

Associations: This bone was found on the 
west edge of Test Unit 8, $0.7 \mathrm{~m}$ north of Burial 1 and $1.0 \mathrm{~m}$ northeast of Burial 3, at an elevation of $100.21 \mathrm{~m}$ (21-22 cm lower than Burials 1 and 3 ). Based on proximity, it could be associated with either, having been moved out of its original context by bioturbation.

\section{ISOLATED BONE 2}

Description: Isolated Bone 2 is a human femur, found lying at a somewhat steep angle, suggesting perhaps a secondary context. The femur is highly fragmented, consisting of over 20 pieces $(33.8 \mathrm{~g})$. The maximum fragment length is $4.94 \mathrm{~cm}$, and the maximum length reconstructed is ca. $14 \mathrm{~cm}$, although this does not incorporate all the fragments. The cortical surface has been almost entirely obliterated by rodent gnawing, but some remnants of the linea aspera remain. A small fragment $(1 \mathrm{x} 1 \mathrm{~cm})$ of unidentifiable long bone was found within $10 \mathrm{~cm}$, but its relationship to the femur was unclear.

Age/Sex/Pathology: The overall size and robusticity of the bone are consistent with an adult. No other indicators of age or sex were observed. No measurements were possible due to the bone's incompleteness and poor condition. No pathology is observable.

Associations: This bone was recovered $1.0 \mathrm{~m}$ northwest of Burial 4 and at nearly the same elevation (100.58 m); hence, it may be associated.

\section{ISOLATED BONE 3}

Description: In-field observations during the second phase of testing suggested this consisted of several fragments of a possibly human long bone. Over 10 pieces of this badly fragmented bone, weighing just $2.9 \mathrm{~g}$, were recovered. The maximum fragment length is $2.36 \mathrm{~cm}$. The fragments are from a long bone, but the cortex appears to be too thick and dense for the bone to be human.

Age / Sex / Pathology: NA/Not observable.

Associations: Isolated Bone 3 was found at the west edge of the West Block, well removed $(7.3 \mathrm{~m})$ from the nearest grave (Burial 4). This, along with its much lower elevation than the burials $(99.93 \mathrm{~m})$, contributes to the argument that it is nonhuman. It is interpreted as an animal bone associated with the general occupational debris at 41BU51.

\section{BIOARCHEOLOGICAL DATA}

This section summarizes the bioarcheological data from 41BU51, and what could be gleaned from earlier analyses of osteological remains from three other sites in this part of the Brazos River valley: 41BU16 (Steele 1987); Winnie's Mound, or 41BU17 (Bowman 1985); and Foster, or 41MM13 (Bowman 1991, 2008). As noted in Chapter 2, reanalysis of the remains from these three sites, along with radiocarbon dating and isotopic studies, was planned as part of this study but did not come to fruition, forcing reliance on previous analyses.

At 41BU16, on a Brazos River terrace $15 \mathrm{~km}$ north-northwest of the current project area, four burials were found in ca. $38 \mathrm{~m}^{2}$ of hand excavation, with a fifth disturbed burial found ca. $5 \mathrm{~m}$ from the excavated area during previous work (Roemer and Carlson 1987). Four of the burials were flexed; the fifth consisted only of teeth. Artifacts were found in the sediments around the burials, but they appear to represent occupational debris rather than grave offerings, with the possible exception of a Gary dart point found close to one feature. The ages of the burials are not known, but the diagnostic artifacts from nonburial contexts at 41BU16 suggest that the site dates chiefly to the Late Archaic and Late Prehistoric periods.

The Winnie's Mound site is on a Brazos River terrace $11 \mathrm{~km}$ north-northwest of 41BU51. Twelve burials and many human teeth and bone fragments that could not be related to specific burials were found in ca. $46 \mathrm{~m}^{2}$ of hand excavation (Bowman 1985). Five of the burials were flexed, and 2 were secondary bundle burials. One interment consisted only of the skull, and the other 4 consisted of disturbed, disarticulated remains for which burial type could not be determined. None of the burials were accompanied by artifacts interpreted as grave offerings. Judging by the depths of the features and the diagnostic artifacts from nonburial contexts, 9 burials appear to date to the Late Archaic period and 3 appear to be Late Prehistoric.

The Foster site is located where the Little River joins the Brazos River, 44 km north-northwest of 41BU51 (Bowman 1991, 2008). Two burials were excavated there. One appears to be the cremated remains of a single individual in three nearby pits. No grave offerings were found. Based on artifacts recovered at a similar depth 
but not associated with the grave, this burial could date to the Late Archaic period. The second burial was that of a semiflexed individual and also lacked accompanying grave goods. It, too, may date to the Late Archaic period, or possibly the Late Prehistoric period.

Before any discussion of the demographic and pathological aspects of the remains from 41BU51 and the other sites can take place, several caveats must be stated. The small number of individuals recovered from 41BU51, as well as the dearth of elements and the generally poor condition of what is present, preclude much in-depth discussion. Even with large samples, the interpretation of paleodemographic and paleopathological data from archeological sites can be problematic (Wood et al. 1992). Similar issues affect the data from other cemetery sites within this part of the Brazos River valley. Data for any given analysis category may be lacking for most burials at a site. For example, the poor condition of long bones, even if present, may make assessment of infection or inflammation impossible. Ideally, basic comparison of paleoepidemiological indicators would include only those interments with the relevant category. For example, in estimating the prevalence of caries, one would want to include only those individuals with teeth present and analyzable, and not the entire burial sample. Differing methods of reporting make it difficult to distinguish elements that were present and analyzed but showed no pathology from those that were absent entirely. Differing or inexplicit methods of analysis (e.g., dental wear assessment that uses terms like "slight" or "moderate" rather than standard scores) also make direct comparison difficult. Finally, the temporal assessments of the burials at 41BU51 and other nearby sites are speculative, as none have been dated directly by radiocarbon or any other method.

\section{Demography}

The available data suggests all the individuals recovered from 41BU51 were adults at the time of death. Preservation typically biases against the preservation of children, and the overall poor condition of the skeletons at the site suggests that few children's skeletons would have been preserved if they had been interred. Of the 23 individuals recovered in the immediate study area (including 41BU51), only 2 are children: 1 at Winnie's Mound (excluding 4 nonaged burials) and 1 at 41BU16. Along with the problem of small sample size, published adult age ranges are often broad, and there is a bias toward younger and middle adults. Otherwise, there seems little of note in the age demographic data.

As noted above, there has been a predilection to overestimate the number of females from sites in the area when sexing is based on skeletal robusticity (D. Gentry Steele, personal communication to Bradley Bowman, December 16, 1986, reported in Bowman 2008:230). All four adults from 41BU16 and both adults at the Foster site were identified as females. The only sexed skeleton at Winnie's Mound, in the later group of burials, was identified as male, but the author later noted the unsexed skeletons, in both the earlier and later groups, all exhibited gracile traits (Bowman 2008:230). This bias might also be found at 41BU51, where both crania exhibit female (though admittedly limited) characteristics and the postcranial bones are relatively gracile. This contrasts with the robusticity observed in Texas coastal populations (Copas 1984:6; Huebner 1992:94). If populations in this area of Texas were gracile, and this trait was maintained for a length of time through prehistory, it may suggest some genetic continuity through time. This avenue of research also could help elucidate the postulated relations between the George C. Davis site and hunter-gatherers on the Blackland Prairie and Oak Woodlands (Shafer 2006). Currently, however, there are no data on the robusticity of the George C. Davis site skeletons.

\section{Pathology}

The heavy dental attrition observed in Burial 3 at 41BU51 is in accord with that seen elsewhere in the Brazos River valley and adjacent regions, and in hunter-gatherers in general. This is generally attributable to the fact that these people ate a coarse diet and often used stone implements to process food. The sandy soils of the region would also provide a steady source of incidental grit in the mouth. In their review of the diet of natives inhabiting the Lower Pecos region of Texas-groups with heavy dental wear comparable to that at 41BU51-Hartnady and Rose (1991:273-276) discuss the archeological, coprolite, microwear, and ethnohistoric 
evidence of dietary abrasives. These abrasives include fruits, seeds, and nuts; chewing of fibrous prickly pear, sotol, and lecheguilla, (and also yucca and agave [Sobolik 1991]), as well as small bones from fish and small mammals; the use of limestone manos and metates in food processing; limestone, ash, and dirt introduced during sotol baking; and dirt added to sweeten meals. Although equivalent data from the Brazos valley are lacking, comparable factors could be applied to the groups that frequented 41BU51.

The Pecos groups, however, showed high rates of caries, an unusual occurrence because heavy wear buffers against caries, as the grooves and fissures that are prime spots for lesion formation are obliterated before any can occur (reviewed in Larsen 1997:66-67). It should be kept in mind that exactly how many caries constitutes a high rate, versus a low or moderate one, has not been qualified or quantified. The high rate of caries was attributed to eating sticky, carbohydrate-rich foods, particularly prickly pear, sotol, and lecheguilla, that adhere to even smooth, worn-down tooth surfaces.

Whether Brazos valley groups might have eaten foods with similar properties is difficult to assess. Overall dental health is poorly understood due to the few teeth recovered. Dental data are specifically reported for only three or four individuals at Winnie's Mound and four of the five individuals at 41BU16. Caries were reported in two individuals total, one at each site. No specific information on the number of teeth present with each burial or the number and location of caries are given for Winnie's Mound, nor is the degree of wear in the dentition of the individual with caries reported. The Winnie's Mound burials for which wear data are given are all described simply as "worn." Caries were observed in a younger adult with relatively little dental wear at 41BU16, although illustration of the dentition of the other three burials suggests caries would have been identified if present originally. Overall, these data do not suggest a diet overly dependent on sticky carbohydrates, although certainly if attrition is high enough (although how high attrition must be to buffer has not been adequately addressed), it may obliterate any evidence of caries. The teeth of Burial 3 at 41BU51 certainly are worn down enough to have done just that. The lack of calculus-mineralized plaque that accumulates on the teeth as a result of poor dental hygiene and a high carbohydrate diet (Hillson 1996:255-260)—may also be some evidence of a lack of such foods in the diet.

The abscessed molar observed in Burial 3, the first observed in the immediate study area, could be seen as indirect evidence of caries, which is often identified as the culprit initiating this process. In this painful condition, exposure of the pulp chamber of the tooth after enamel and dentin loss leads to pulp death, inflammation of the periapical alveolar bone, and resultant alveolar bone destruction. Secondary sepis may also result (Langsjoen 1998:399; Ortner 2003:592). However, excessive attrition, where dentin loss is faster than secondary dentin deposition, can also lead to pulp death and alveolar bone loss. This seems a more likely cause at 41BU51, considering the extreme wear on all the teeth. Diet, poor dental hygiene, and dental wear make abscesses a relatively common phenomenon in hunter-gatherers.

Excessive attrition is also implicated in the widespread hypercementosis in Burial 3. Hypercementosis, a symptomless condition, is the excessive deposition of the cement that coats the roots of the teeth and provides attachment for the periodontal ligament to the root (Hillson 1996:198-199). It is related to heavy dental attrition and malocclusion and is observed in cases of Paget's disease (Hillson 1996:205). Comuzzie and Steele (1989:13), in their analysis of huntergatherers with severe dental attrition and hypercementosis from the Blue Bayou (41VT94), Palm Harbor (41AS80), Oso Creek (41NU37), and Cayo del Oso (41NU2) sites along the Gulf Coast of Texas, suggest, after Spouge (1973), that secondary cementum formation strengthened the anchoring of the teeth in their sockets as they underwent occlusal stress. This seems a reasonable interpretation for its presence in Burial 3 as well.

The well-healed compact bone formation observed on the tibia of Burial 2 is also a common phenomenon, typically referred to as periostitis. This condition, which occurs secondary to inflammation of the periosteum covering the bone, may be caused by bleeding, infection, trauma, and ulcers (Aufderheide and Rodríguez-Martín 1998:179). The anterior crest of the tibia, with its lack of overlying protective soft tissue, is particularly vulnerable to trauma, which is perhaps most often implicated in inflammation and the development of periostitis at that site (Ortner 2003:208-209). Unilateral bone formation and 
anterior-posterior bowing on a tibia at $41 \mathrm{BU} 16$ are tentatively interpreted as treponemal infection (Steele 1987:201), but there is no indication of this at 41BU51. Otherwise, there is no evidence for skeletal infection in the study area, excluding the subperiosteal bone deposition on the cranium of the cremation at the Foster site, which is difficult to interpret. Periostitis is commonly used to assess the overall health of populations (Ortner 2003:209), although, like many lesions, the prevalence of the lesion in a skeletal sample should not necessarily be taken as a direct measure of health of the group from which it is derived. Those individuals with lesions may actually represent the survivors of disease, and thus the healthier members of a group, while the weaker members die before any lesions become manifest on the bone (Wood et al. 1992). In addition, multiple possible etiologies make direct comparison difficult.

Periostotic lesions like those at 41BU51, if they result from trauma, typically represent accidental rather than intentional trauma. Overall, there is only limited evidence for interpersonal violence in the region. At Winnie's Mound, Late Prehistoric Burial 2 had a healed fracture near the midshaft of the right ulna. Ulnar fractures could be the result of an accident, or a blow delivered when the forearm is raised in a defensive posture, a so-called parry fracture. The latter usually occur on the distal third of the shaft (Galloway 1999:143-146). Without details on the fracture's exact location and type, little else can be said. At the Foster site, the superiorlateral surface of the left clavicle of Individual 2 has a longitudinal fracture that seems to be healing or healed (Bowman 2008:235-236). However, the location of the fracture, which bears on its interpretation, is not specified, nor is the fracture itself adequately described. Accidents cause most clavicle fractures in modern samples (Galloway 1999:114-115), and if this is indeed a longitudinal fracture, it is unlikely to be the result of an intentional blow. Such fractures most often result from torsional stresses (Ortner 2003:122), while violent blows often result in transverse breaks. The frontals on this person also are reported to exhibit chop or cut marks around both orbital borders, but it is difficult to evaluate the significance of this unusual occurrence.

It is worth mentioning some of the pathologies commonly observed in analyses of human remains but essentially not observable at 41BU51. Degenerative joint disease, especially of the vertebral column, is perhaps the most commonly observed pathology, but it cannot be assessed when joint surfaces are lost. Cranial hyperostosis, cribra orbitalia, and linear enamel hypoplasias of the permanent dentition are all indicators of metabolic or physiologic insult during childhood. Porotic hyperostosis and cribra orbitalia-lesions of the outer table of the cranium and superior roof of the eye orbits that occur when the cancellous bone of the diploic space expands and the outer table of bone resorbs, leaving a porous bone surface-are both indicators of iron-deficiency anemia, most often due to dietary deficiency or parasite load (Lallo et al. 1977; Stuart-Macadam 1987, 1992). Lesions become manifest primarily between the ages of six months and two years (Lallo et al. 1977; Stuart-Macadam 1989). A case of possible porotic hyperostosis was recorded at 41BU16. Enamel hypoplasias are nonspecific indicators of stress, particularly diet- and disease-related stress, that occur between birth and roughly six years as a result of disrupted enamel formation. They are visible as vertical or horizontal lines, bands, or pits on the enamel surface (Goodman et al. 1980; Rose et al. 1985). No hypoplasias have been documented in the study area, although heavy dental wear will obliterate any evidence of them. 



\section{ARTIFACTS RECOVERED}

Cultural materials encountered during the excavations, other than the human remains discussed in Chapter 3, consist of chipped stone tools, debitage, cores, and tested cobbles; ground, battered, and striated stones; ceramic sherds; burned clay nodules; burned rocks; possibly flaked silicified wood; small amounts of charcoal and faunal remains; and a few historic artifacts. By far the largest artifact category is lithic debitage, with 9,944 pieces, of which 72 are edge-modified. Formal chipped stone tools consist only of projectile points and preforms, bifaces, and unifaces. Ten of the projectile points are arrow points, and 23 are dart points. The assemblage includes 21 bifaces and 2 unifaces. Twenty-two cores and 5 tested cobbles round out the collection of chipped stone artifacts. There are 10 pieces of ground, battered, or striated stones. The ceramic sample is small, consisting of just 8 undecorated body sherds and 1 rim sherd.

\section{CHIPPED STONE ARTIFACTS}

\section{Dart Points}

The dart points are classified as Bulverde, Carrollton, Darl, Edgewood, Godley, Marcos, Meserve, Morrill, Nolan, Pedernales, and Fort Hood Provisional Type 1, along with a few untyped and untypeable specimens. Provenience and metric information are provided in Table 4.1.

Four Bulverde dart points were collected, the highest recovery of a single point type (Figure $4.1 \mathrm{a}-\mathrm{b}$ ). Three of the four are complete, and one is a proximal fragment missing most of the blade. The three larger specimens are of gray to brown chert with white fossiliferous inclusions. The fourth, smaller point (Figure 4.1b) is reddish brown chert that has been heated. One was found in manual excavations during testing, and three were recovered during Gradall excavations.

Two Carrollton dart points were recovered, one during test unit excavation and one during Gradall scraping. One is a complete specimen of pale brown chert with dark inclusions (Figure 4.1c). The other is almost complete, with impact fractures at the distal tip and one shoulder (Figure 4.1d); it is of homogeneous brownish yellow chert.

Two Darl points were collected. One is a proximal stem fragment from Test Unit 7; it is of very dark brown chert. The second specimen is complete, although the base has a slight bending fracture and the distal tip has been reworked (Figure 4.1e). This point, which was collected during Gradall stripping, is of brown to grayish brown chert with white inclusions.

The single Edgewood point, of reddish brown chert, is a medial and proximal fragment with a distal impact fracture and heat damage. The expanding base is concave, and the shoulders are weak. It was found during Gradall excavation.

One proximal stem fragment from Test Unit 11 appears to be from a Godley point. The expanding stem is slightly rounded and convex. It is of mottled dark yellowish brown chert.

One almost-complete Marcos point was collected during Gradall stripping (Figure 4.1f). The tips of both barbs, one corner of a basal ear, and the distal tip are broken, and the distal end has been reworked slightly. The point is of light gray and very pale brown chert with dark inclusions.

The earliest dart recovered is a Meserve point (Figure $4.1 \mathrm{~g}$ ). The almost-complete specimen was collected during Gradall stripping. The broken distal end has been reworked. The concave base and stem edges are heavily ground. 
Testing and Data Recovery Excavations at 41BU51

\begin{tabular}{|c|c|c|c|c|c|c|c|c|c|c|c|c|c|c|c|c|c|c|c|c|}
\hline 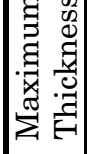 & & & $\mid \begin{array}{l}0 \\
\dot{0} \\
\dot{0}\end{array}$ & & 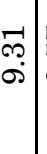 & $\begin{array}{l}1 \\
10 \\
\infty \\
0\end{array}$ & 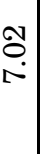 & 1 & & $1 \mid \begin{array}{l}0 \\
0 \\
0\end{array}$ & 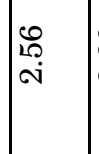 & $\left|\begin{array}{c}\infty \\
\infty \\
\infty \\
\infty\end{array}\right|$ & $\mid \begin{array}{l}8 \\
\infty \\
\infty\end{array}$ & 1 & 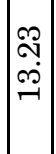 & $\mid \begin{array}{l}\infty \\
0 \\
0 \\
0\end{array}$ & 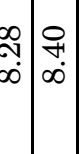 & تُ & 11 & 1 \\
\hline $\begin{array}{l}0 \\
0 \\
0 \\
0 \\
0 \\
0 \\
0 \\
0 \\
0 \\
0\end{array}$ & $\begin{array}{l}\qquad \\
\dot{0} \\
\dot{0} \\
-1 \\
\end{array}$ & 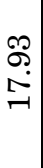 & 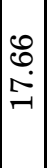 & & 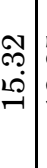 & $\mid \begin{array}{l}10 \\
\infty \\
9 \\
-9 \\
-1\end{array}$ & 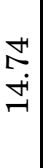 & \begin{tabular}{l|}
\multicolumn{1}{c}{} \\
$\infty$ \\
$\dot{0}$ \\
-1
\end{tabular} & $\mid$\begin{tabular}{c|c}
10 \\
9 \\
0 \\
-1 & 0 \\
-15
\end{tabular} & 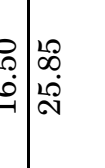 & 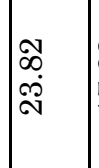 & 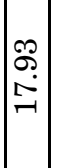 & 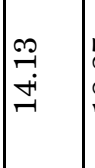 & 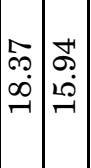 & $\left|\begin{array}{l}\infty \\
-1 \\
0 \\
-1 \\
-1\end{array}\right|$ & 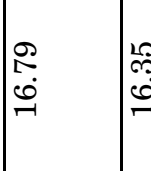 & 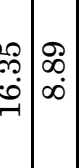 & $\begin{array}{l}\stackrel{\infty}{+} \\
\stackrel{\leftrightarrow}{\sim}\end{array}$ & $\mid \begin{array}{l}1 \\
0 \\
0 \\
0 \\
-1\end{array}$ & 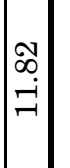 \\
\hline 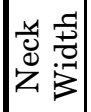 & 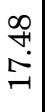 & $\begin{array}{l}0 \\
+1 \\
\infty \\
\infty \\
-1\end{array}$ & $\mid \begin{array}{l}-1 \\
\infty \\
\infty \\
-1\end{array}$ & $\begin{array}{l}\stackrel{N}{N} \\
+ \\
+ \\
-1\end{array}$ & 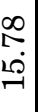 & $\begin{array}{l}\hat{N} \\
\text { No } \\
0 \\
-\end{array}$ & \begin{tabular}{l} 
जิ \\
ป̀ \\
\multirow{y}{*}{}
\end{tabular} & 1 & 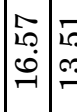 & 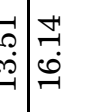 & & 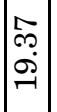 & $\mid \begin{array}{l}20 \\
200 \\
100 \\
10\end{array}$ & 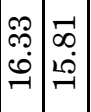 & $\mid \begin{array}{l}0 \\
0 \\
\infty \\
-1 \\
-1\end{array}$ & $\begin{array}{l}\stackrel{2}{S} \\
\stackrel{+}{-}\end{array}$ & 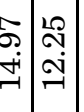 & $\begin{array}{l}20 \\
\infty \\
\infty \\
\\
\end{array}$ & 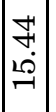 & 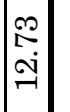 \\
\hline 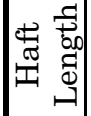 & & $\begin{array}{l}4 \\
0 \\
\dot{2} \\
\end{array}$ & $\mid$ & & $\begin{array}{c}0 \\
\infty \\
0 \\
-1\end{array}$ & 㢳 & $\begin{array}{l}\stackrel{T}{\ddagger} \\
\stackrel{5}{*}\end{array}$ & 1 & 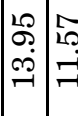 & $=$ & $\begin{array}{l}\infty \\
-1 \\
0 \\
-1\end{array}$ & $\mid \begin{array}{l}\infty \\
\infty \\
\dot{2} \\
-\end{array}$ & : & 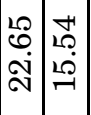 & $\begin{array}{l}\stackrel{\Omega}{二} \\
\underset{+}{-}\end{array}$ & 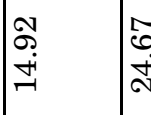 & 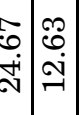 & 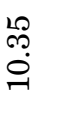 & $\begin{array}{l}\infty \\
\infty \\
\stackrel{-}{-} \\
\end{array}$ & 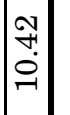 \\
\hline 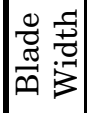 & 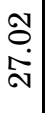 & $\begin{array}{l}0 \\
\stackrel{0}{2} \\
\text { L. } \\
\text { - }\end{array}$ & $\begin{array}{l}\stackrel{P}{+} \\
\stackrel{+}{+} \\
\stackrel{1}{|c|}\end{array}$ & 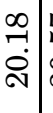 & & & 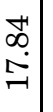 & 1 & & 1 & 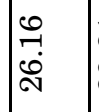 & 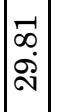 & $\begin{array}{l}\stackrel{P}{\Gamma} \\
\text { - } \\
\text { N }\end{array}$ & I $\left|\begin{array}{l}\infty \\
\infty \\
\stackrel{+}{N}\end{array}\right|$ & 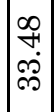 & $\begin{array}{l}\stackrel{N}{\infty} \\
\stackrel{\sim}{*} \\
\stackrel{\sim}{N}\end{array}$ & 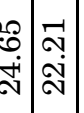 & $\begin{array}{l}\stackrel{0}{N} \\
\stackrel{0}{0} \\
\text { N }\end{array}$ & 11 & 1 \\
\hline 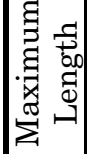 & & $\mid \begin{array}{l}\Omega \\
2 \\
8 \\
0\end{array}$ & 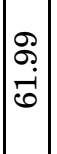 & 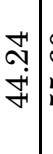 & & & $\begin{array}{l}8 \\
\dot{1} \\
\end{array}$ & 1 & & $1 \mid \begin{array}{l}0 \\
1 \\
\dot{8} \\
0\end{array}$ & & $\left|\begin{array}{l}\stackrel{19}{+} \\
\dot{\infty} \\
\infty\end{array}\right|$ & $\begin{array}{l}\infty \\
\infty \\
0 \\
10\end{array}$ & 1 & $\begin{array}{l}\Omega \\
\stackrel{\Omega}{0} \\
\dot{0}\end{array} \mid$ & 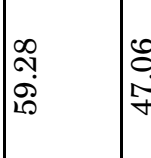 & \begin{tabular}{c}
0 \\
0 \\
\multirow{4}{*}{} \\
\end{tabular} & 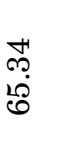 & 11 & 1 \\
\hline 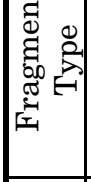 & 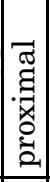 & $\begin{array}{l}0 \\
0 \\
0 \\
2 \\
0 \\
0 \\
\end{array}$ & 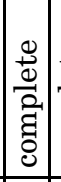 & 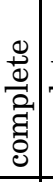 & 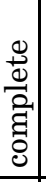 & 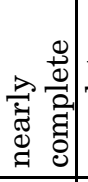 & 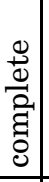 & 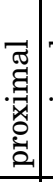 & 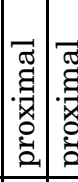 & 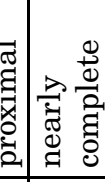 & 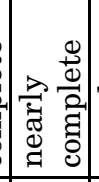 & 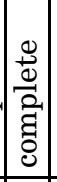 & 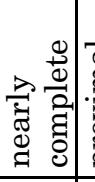 & 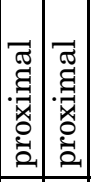 & 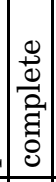 & 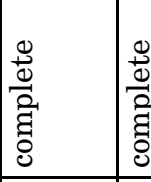 & 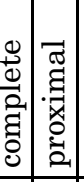 & 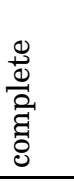 & 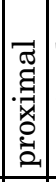 & 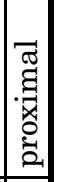 \\
\hline 总 & 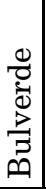 & 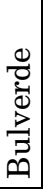 & 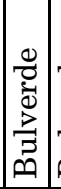 & 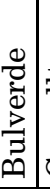 & 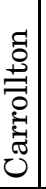 & 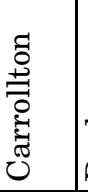 & $\overrightarrow{\tilde{\Xi}}$ & $\overrightarrow{\tilde{\Xi}}$ & 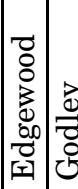 & 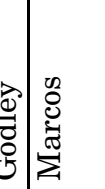 & 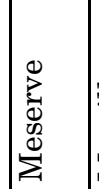 & $\mid \begin{array}{c}F \\
\overline{2} \\
0 \\
\Sigma \\
\Sigma\end{array}$ & $\begin{array}{l}\frac{\text { ă }}{0} \\
\text { ż }\end{array}$ & 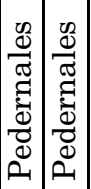 & 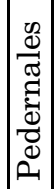 & 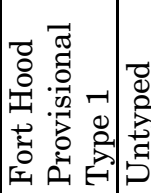 & 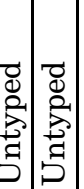 & 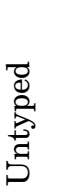 & 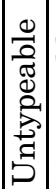 & 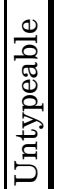 \\
\hline 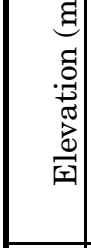 & $\begin{array}{l}0 \\
0 \\
+1 \\
8 \\
1 \\
1 \\
0 \\
10 \\
0 \\
0 \\
1\end{array}$ & $\begin{array}{l}+1 \\
10 \\
8 \\
8 \\
0 \\
\end{array}$ & \begin{tabular}{|c}
5 \\
0 \\
$\dot{0}$ \\
0 \\
\end{tabular} & $\begin{array}{l}0 \\
0 \\
\dot{8} \\
0 \\
\end{array}$ & $\begin{array}{l}0 \\
0 \\
0 \\
0 \\
-1 \\
0 \\
0 \\
0 \\
\dot{0} \\
0 \\
-1\end{array}$ & $\begin{array}{l}\mathscr{S} \\
\dot{g} \\
\dot{S}\end{array}$ & $\begin{array}{l}1 \\
10 \\
8 \\
0 \\
-1 \\
\end{array}$ & $\begin{array}{l}0 \\
\infty \\
\dot{8} \\
0 \\
-1 \\
0 \\
0 \\
0 \\
0 \\
0 \\
-1\end{array}$ & 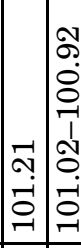 & 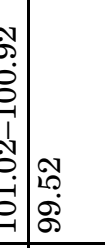 & 용 & \begin{tabular}{|l|} 
\\
$\mathscr{8}$ \\
$\dot{\delta}$ \\
\end{tabular} & $\begin{array}{l}0 \\
0 \\
8 \\
8 \\
1 \\
0 \\
0 \\
0 \\
0 \\
0 \\
0\end{array}$ & 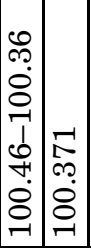 & 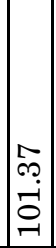 & 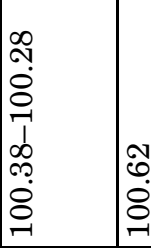 & 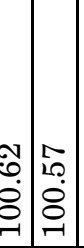 & $\begin{array}{l}\stackrel{0}{0} \\
+1 \\
\dot{8} \\
0\end{array}$ & $\mid \begin{array}{c}0 \\
0 \\
0 \\
0 \\
0 \\
-1 \\
\infty \\
0 \\
+ \\
\dot{0} \\
0 \\
-1\end{array}$ & 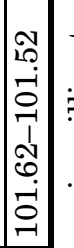 \\
\hline 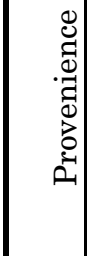 & 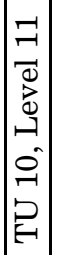 & 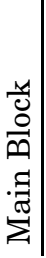 & 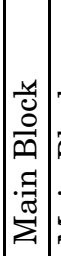 & 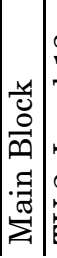 & 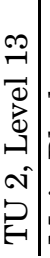 & 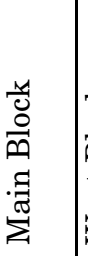 & 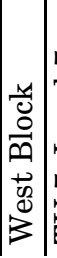 & 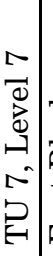 & 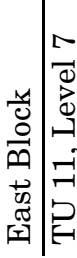 & 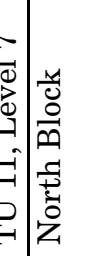 & 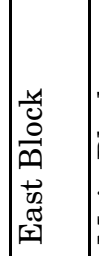 & 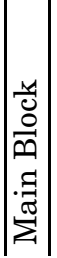 & 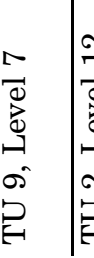 & 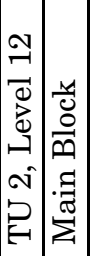 & 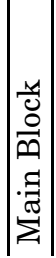 & 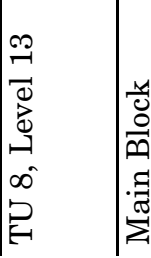 & 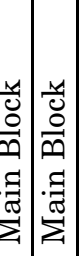 & 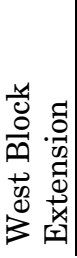 & 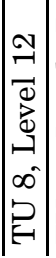 & 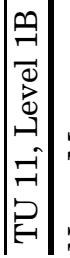 \\
\hline
\end{tabular}




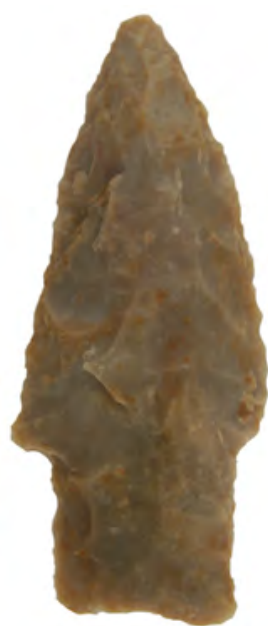

a
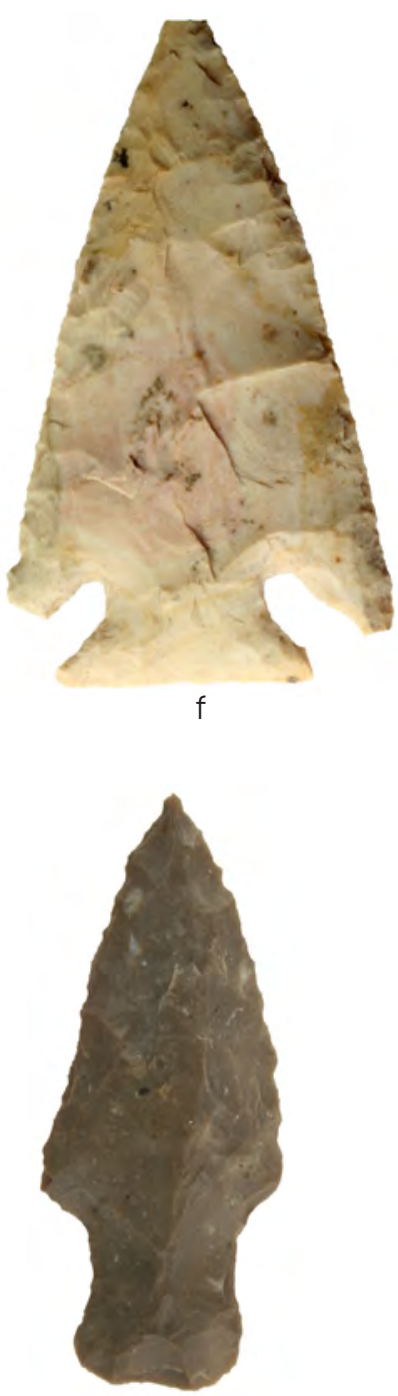

k

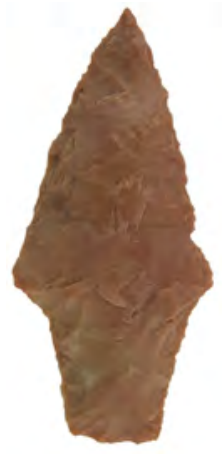

b

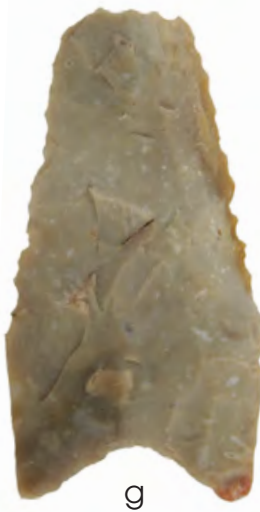

g

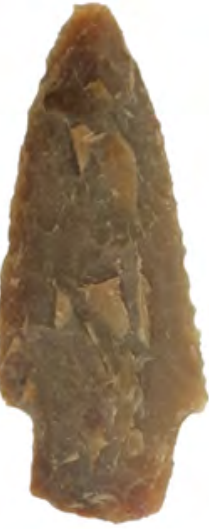

।

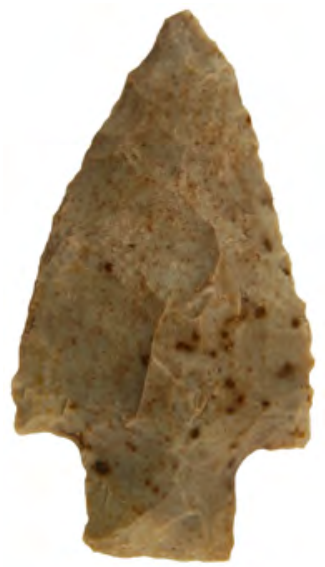

C

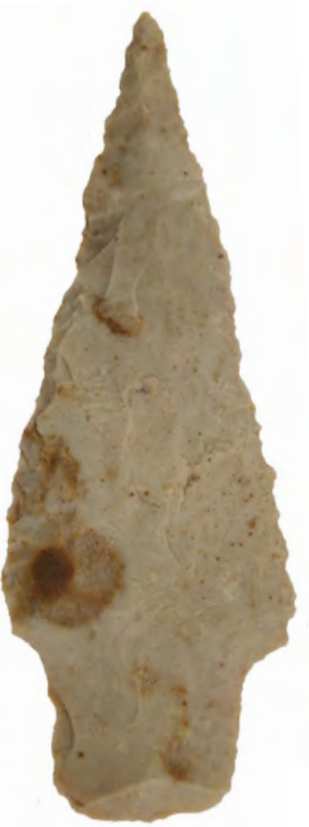

h

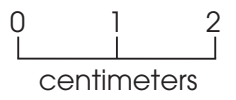

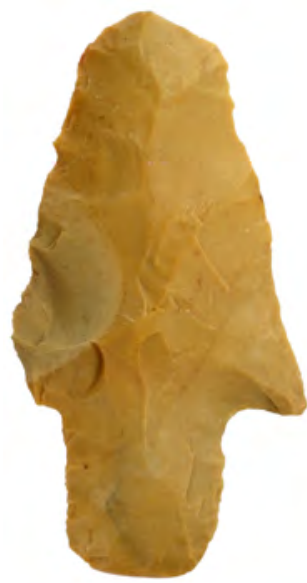

d
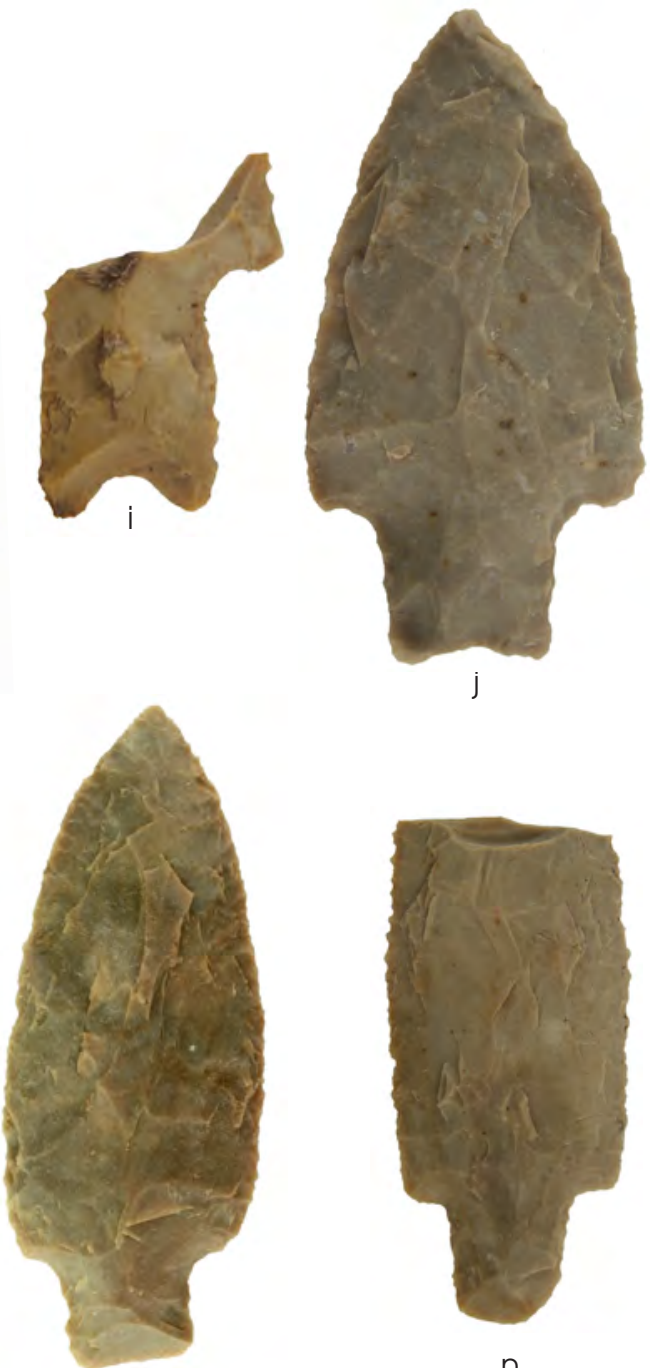

m

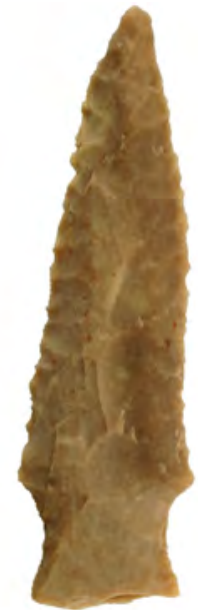

e

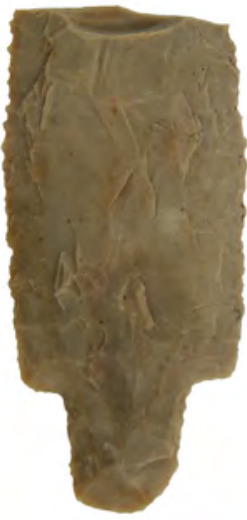

$\mathrm{n}$

Figure 4.1. Dart points recovered. (a-b) Bulverde; (c-d) Carrollton; (e) Darl; (f) Marcos; (g) Meserve; (h) Morrill; (i-j) Pedernales; (k) Provisional Type 1; (l-n) untyped. 
It is made of light brownish gray to yellowish brown chert with white inclusions.

One Morrill point was collected from the backdirt during Gradall stripping (Figure 4.1h). It is complete with a reworked distal tip. It is of very pale brown chert with dark inclusions.

A Nolan point was recovered from Test Unit 9. The specimen exhibits the characteristic alternate beveling on the stem and blade edges with weak pointed shoulders. It is almost complete, lacking only the distal tip. It is of dark brown chert.

Three Pedernales points were recovered, two proximal fragments and one complete specimen. One of the fragments consists of the stem and one shoulder; it is of light yellowish brown chert (Figure 4.1i). The second fragment, consisting of the stem and lowermost part of the blade, is of reddish brown, heated chert. The complete point is very thick and has strongly convex blade margins (Figure 4.1j); it is of grayish brown chert with white inclusions. Two of these are from the Gradall excavations, and one was found in test unit excavations.

One complete point from Test Unit 8 is similar to Fort Hood Provisional Type 1, which Kleinbach et al. (1995:335-344) argue dates to the Late Archaic period, and perhaps the latter part of the Middle Archaic period, in central Texas. It has a long, slightly expanding stem with ground edges and a blade with straight to convex margins (Figure $4.1 \mathrm{k}$ ). It is of dark grayish brown chert.

Three dart points recovered during Gradall stripping are untyped. One has a slightly expanding stem with straight base and a blade with straight to convex margins and weak shoulders (Figure 4.11). Both the base and tip have been reworked. It is of very pale brown chert. The other two have long blades with convex margins and small rectangular stems (Figure $4.1 \mathrm{~m}-\mathrm{n}$ ). One is complete with one reworked shoulder; it is of gray chert. The other has a distal bending fracture and neatly serrated blade edges. The base is comparatively narrow, and one ear has been reworked; it is of pale brown chert.

Two dart point fragments from Test Units 8 and 11 are untypeable. One is a rectangular stem and lower portion of one shoulder of pale brown chert. The other is a square to slightly contracting stem with convex base, also of pale brown chert with remnant dark yellowish brown cortex.

\section{Arrow Points}

Ten arrow points were recovered. One is an Edwards, 1 is a Fresno, 2 are Scallorn points, 2 are untyped fragments, and 4 are preforms. Metric and provenience information is provided in Table 4.2 .

The Edwards specimen is nearly complete with an impact fracture to the distal tip and a fracture on one side of the base (Figure 4.2a). It was collected during Gradall stripping near Isolated Bone 2, but at an elevation $12 \mathrm{~cm}$ lower. It is of pale brown chert mottled with darker brown specks.

The Fresno is a complete specimen (Figure $4.2 \mathrm{~b}$ ) and also was collected near Isolated Bone 2 and at the same elevation. It is of light brownish gray chert.

The two Scallorn points, both from Test Unit 6, are proximal fragments, with one also having a fracture on one ear of the base (Figure $4.2 \mathrm{c}-\mathrm{d})$. They are of pale brown to very pale brown chert.

Two untypeable arrow point fragments were recovered. One, from Test Unit 6, appears to be a distal fragment. The second, from Test Unit 7, appears to be a base fragment. They are of light gray and brown chert.

Four arrow point preforms were recovered from Test Units, 2, 3, 6, and 7. One is a unifacially worked ovate flake with a pointed distal tip (Figure 4.2e); it is of yellowish brown chert with a patch of dark yellowish brown cortex on one face. The other three are proximal sections of thin triangular bifaces (Figure 4.2f). All have straight blade margins and straight to slightly convex bases. They are of pale brown to very pale brown chert.

\section{Bifaces}

Four bifaces and 17 biface fragments were recovered. Eight are in the early and middle stages of reduction, while 13 are considered to be in the late stage or finished. Most are not assigned to a particular tool type, but 1 appears to have been destined for use as a scraper and 4 are knives (Figure 4.3); a single tool is a proximal fragment of a finished knife or dart point. Almost all were made from stream-rolled chert cobbles, with the only exceptions consisting of 2 of fine-grained quartzite and 1 of silicified wood. Table 4.3 provides provenience and metric information. 
Table 4.2. Provenience and metric data for arrow points

\begin{tabular}{l|l|l|l|c|c|c|c|c|c}
\hline Provenience & $\begin{array}{l}\text { Elevation } \\
(\mathrm{m})\end{array}$ & \multicolumn{1}{|c|}{ Type } & $\begin{array}{c}\text { Fragment } \\
\text { Type }\end{array}$ & $\begin{array}{c}\text { Maximum } \\
\text { Length }\end{array}$ & $\begin{array}{c}\text { Blade } \\
\text { Width }\end{array}$ & $\begin{array}{c}\text { Haft } \\
\text { Length }\end{array}$ & $\begin{array}{c}\text { Neck } \\
\text { Width }\end{array}$ & $\begin{array}{c}\text { Base } \\
\text { Width }\end{array}$ & $\begin{array}{c}\text { Maximum } \\
\text { Thickness }\end{array}$ \\
\hline West Block & 100.46 & Edwards & $\begin{array}{l}\text { nearly } \\
\text { complete }\end{array}$ & 41.28 & 13.28 & 6.54 & 7.18 & $12.96+$ & 4.67 \\
\hline Main Block & 100.58 & Fresno & complete & 31.34 & 17.2 & & & 17.2 & 5.18 \\
\hline TU 6, Level & $\begin{array}{l}101.56- \\
1 B\end{array}$ & Scallorn & proximal & - & 14.81 & 5.7 & 6.32 & - & 3.86 \\
\hline TU 6, Level 6 & $\begin{array}{l}101.46 \\
100.96-\end{array}$ & Scallorn & proximal & - & 12.39 & 5.42 & 6.05 & 12.59 & 3.32 \\
\hline TU 6, Level 10 & $\begin{array}{l}100.66- \\
100.56\end{array}$ & Untypeable & distal & - & - & - & - & - & - \\
\hline TU 7, Level 1 & $\begin{array}{l}101.62- \\
101.46\end{array}$ & Untypeable & proximal & - & - & - & - & - & - \\
\hline TU 2, Level 6 & $\begin{array}{l}100.06- \\
100.96\end{array}$ & Preform & proximal & - & 17.58 & - & - & 17.58 & 4.26 \\
\hline TU 3, Level 3 & $\begin{array}{l}103.91- \\
103.81\end{array}$ & Preform & complete & 24.99 & 14.99 & - & - & 14.99 & 3.37 \\
\hline TU 6, Level 2 & $\begin{array}{l}101.46- \\
101.36\end{array}$ & Preform & proximal & - & 18.39 & - & - & 18.39 & 3.91 \\
\hline TU 7, Level 2 & $\begin{array}{l}101.46- \\
101.36\end{array}$ & Preform & proximal & - & 18.36 & - & - & 18.36 & 4.21 \\
\hline
\end{tabular}

Note: Measurements are in millimeters.

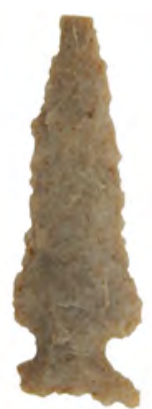

a

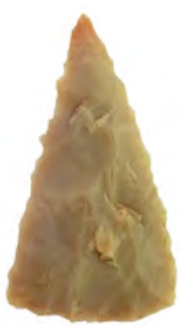

b

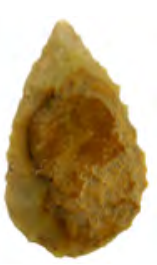

e

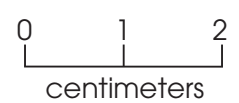

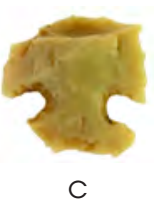

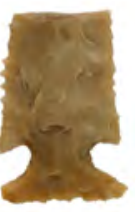

d

Figure 4.2. Arrow points recovered. (a) Edwards; (b) Fresno; (c-d) Scallorn; (e-f) preforms. 
Testing and Data Recovery Excavations at 41BU51

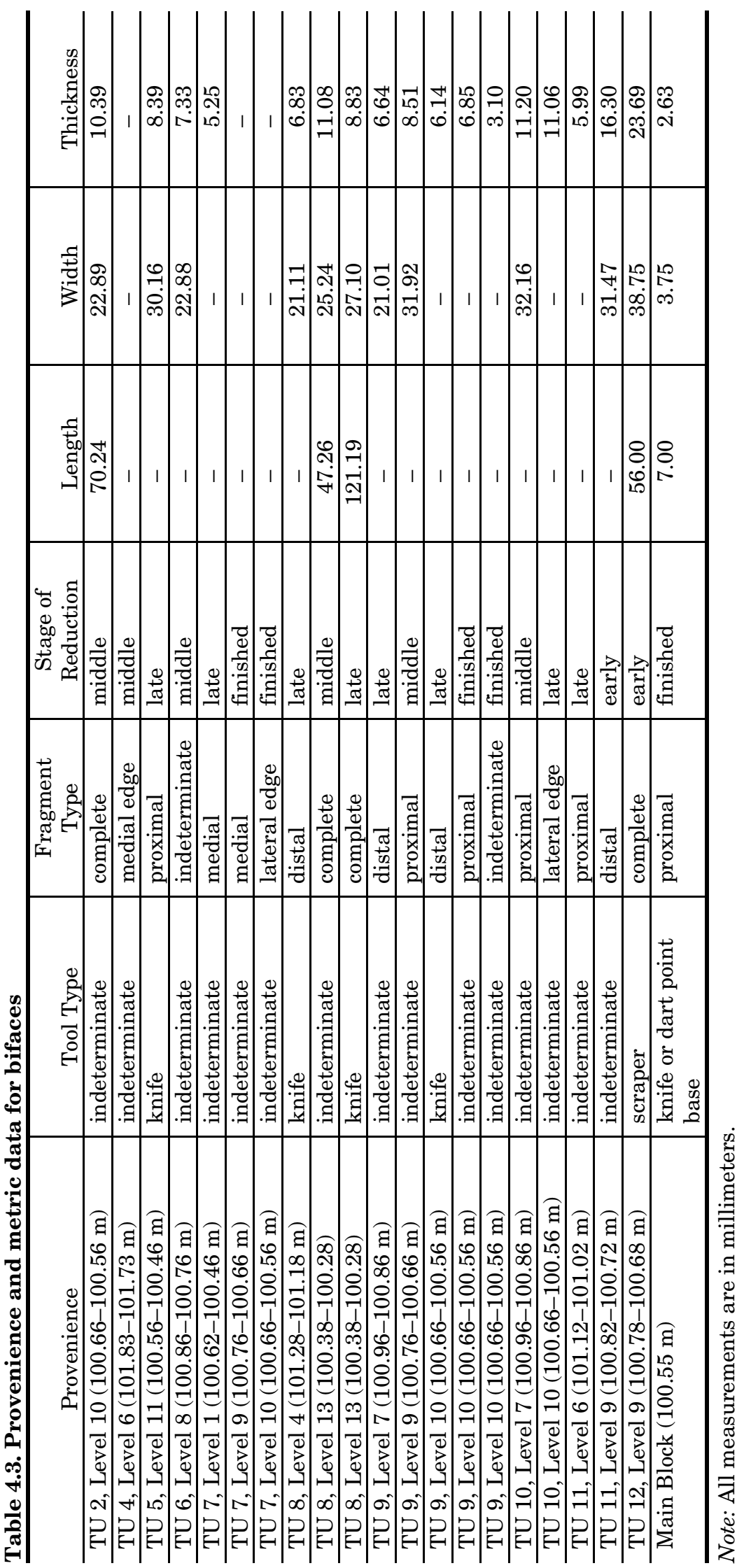




\section{Unifaces}

Only two unifaces were recovered. The first specimen, from Level 11 in Test Unit 11, is a tabular piece of silicified wood with flaking along one lateral margin. It is $38.27 \mathrm{~mm}$ long, $34.30 \mathrm{~mm}$ wide, and $9.25 \mathrm{~mm}$ thick. The second specimen, from Level 13 of Test Unit 12, is a stream-rolled cobble fragment with flaking along one side; the material is yellowish brown chert with dark yellowish brown cortex. The piece is $34.21 \mathrm{~mm}$ long, $31.07 \mathrm{~mm}$ wide, and $22.58 \mathrm{~mm}$ thick.

\section{Edge-Modified Flakes}

Seventy-two edge-modified flakes were distinguished from unmodified ones based on the presence of macroscopically visible microflaking along one or more edges (Table 4.4). Though some of these could have been damaged after deposition, the fact that the microflakes tend to be regular in size and occur adjacent to one another suggests that they mostly reflect intentional edge retouch or modification through use. They range from 15.40 to $75.32 \mathrm{~mm}$ in maximum dimension, averaging $34.40 \mathrm{~mm}$. Other than a

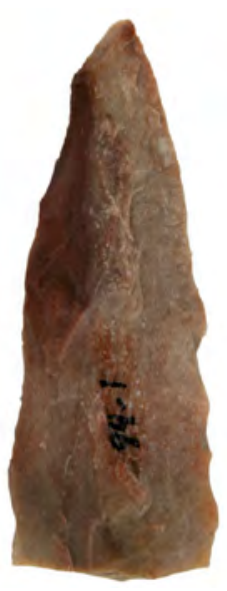

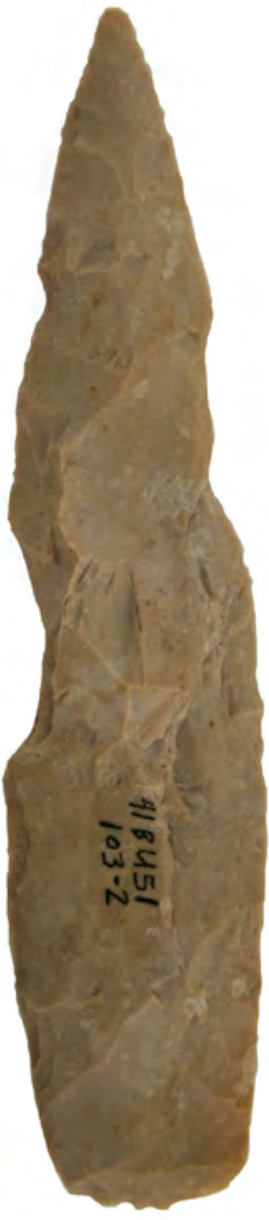
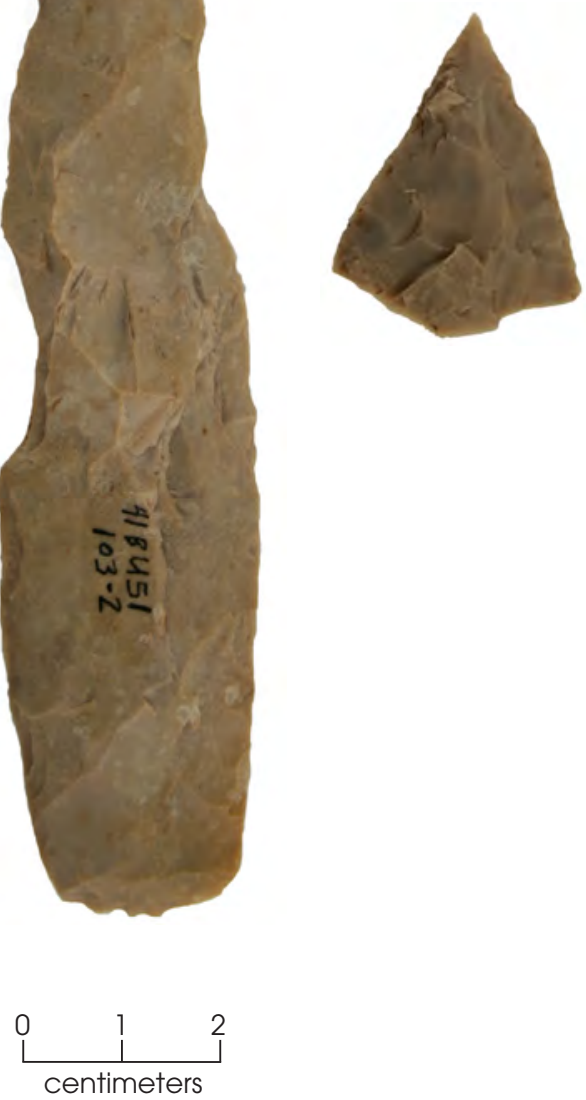

Figure 4.3. Bifacial knives recovered. 
Table 4.4. Provenience, metric, and raw material data for edge-modified flakes

\begin{tabular}{|c|c|c|}
\hline Provenience & $\begin{array}{c}\text { Maximum } \\
\text { Dimension } \\
(\mathrm{mm})\end{array}$ & Material \\
\hline TU 1, Level $2(101.09-100.09 \mathrm{~m})$ & 26.33 & gray chert \\
\hline TU 1, Level 5 (100.79-100.69 m) & 25.79 & dark reddish brown fine-grained quartzite \\
\hline TU 1, Level 6 (100.69-100.59 m) & 40.75 & $\begin{array}{l}\text { brownish yellow chert with dark grayish brown } \\
\text { cortex }\end{array}$ \\
\hline TU 1, Level 7 (100.59-100.49 m) & 32.96 & pale brown chert with dark grayish brown cortex \\
\hline TU 1, Level 8 (100.49-100.39 m) & 32.59 & light brown chert with dark reddish brown cortex \\
\hline TU 1, Level 8 (100.49-100.39 m) & 42.05 & brown chert with dark brown cortex \\
\hline TU 2, Level 4 (101.26-101.16 m) & 22.91 & light yellowish brown chert \\
\hline TU 2, Level 10 (100.66-100.56 m) & 35.33 & $\begin{array}{l}\text { light brownish gray chert with dark yellowish } \\
\text { brown cortex }\end{array}$ \\
\hline TU 2, Level 10 (100.66-100.56 m) & 15.40 & light yellowish brown chert \\
\hline TU 2, Level $11(100.56-100.46 \mathrm{~m})$ & 26.11 & brown chert with dark yellowish brown cortex \\
\hline TU 2, Level $12(100.46-100.36 \mathrm{~m})$ & 52.93 & pale brown chert \\
\hline TU 2, Level 12 (100.46-100.36 m) & 37.88 & $\begin{array}{l}\text { light brownish gray chert with dark yellowish } \\
\text { brown cortex }\end{array}$ \\
\hline TU 2, Level $12(100.46-100.36 \mathrm{~m})$ & 33.47 & $\begin{array}{l}\text { light yellowish brown chert with dark yellowish } \\
\text { brown cortex }\end{array}$ \\
\hline TU 2, Level 13 (100.36-100.26 m) & 61.33 & $\begin{array}{l}\text { light brownish gray chert with dark yellowish } \\
\text { brown cortex }\end{array}$ \\
\hline TU 2, Level $13(100.36-100.26 \mathrm{~m})$ & 37.35 & light reddish brown chert \\
\hline TU 2, Level $14(100.26-100.16 \mathrm{~m})$ & 75.32 & light gray and light brownish gray chert \\
\hline TU 2, Level $14(100.26-100.16 \mathrm{~m})$ & 47.02 & brown chert with dark yellowish brown cortex \\
\hline TU 2, Level 14 (100.26-100.16 m) & 34.51 & $\begin{array}{l}\text { yellowish brown chert with dark yellowish brown } \\
\text { cortex }\end{array}$ \\
\hline TU 2, Level 15 (100.16-100.06 m) & 42.71 & grayish brown chert with very dark gray cortex \\
\hline TU 2, Level $16(100.06-99.96 \mathrm{~m})$ & 43.40 & pale brown chert with dark yellowish brown cortex \\
\hline TU 2, Level $16(100.06-99.96 \mathrm{~m})$ & 33.32 & pale brown chert with dark yellowish brown cortex \\
\hline TU 2, Level 17 (99.96-99.86 m) & 43.10 & light yellowish brown chert with brown cortex \\
\hline TU 2, Level 17 (99.96-99.86 m) & 32.80 & $\begin{array}{l}\text { dark reddish gray chert with dark reddish brown } \\
\text { cortex }\end{array}$ \\
\hline TU 2, Level 17 (99.96-99.86 m) & 33.07 & very pale brown chert \\
\hline TU 4, Level $6(101.83-101.73 \mathrm{~m})$ & 32.74 & light yellowish brown chert \\
\hline TU 4, Level 8 (101.63-101.53 m) & 29.84 & $\begin{array}{l}\text { light yellowish brown chert with dark brown } \\
\text { cortex }\end{array}$ \\
\hline TU 4, Level 10 (101.43-101.33 m) & 26.75 & pale brown chert \\
\hline TU 5, Level 3 (101.36-101.26 m) & 31.39 & pale brown chert \\
\hline TU 5, Level 13 (100.36-100.26 m) & 47.33 & $\begin{array}{l}\text { light yellowish brown chert with dark yellowish } \\
\text { brown cortex }\end{array}$ \\
\hline TU 5, Level $14(100.26-100.16 \mathrm{~m})$ & 33.43 & $\begin{array}{l}\text { yellowish brown chert with dark reddish brown } \\
\text { cortex }\end{array}$ \\
\hline TU 6, Level 2 (101.46-101.36 m) & 30.68 & gray chert \\
\hline TU 6, Level 3 (101.36-101.26 m) & 30.82 & brown chert \\
\hline TU 6, Level 3 (101.36-101.26 m) & 24.13 & $\begin{array}{l}\text { light brownish gray chert with dark reddish brown } \\
\text { cortex }\end{array}$ \\
\hline TU 6, Level 4 (101.26-101.16 m) & 23.54 & brown chert with very dark gray cortex \\
\hline TU 6, Level 4 (101.26-101.16 m) & 26.60 & yellowish brown chert \\
\hline TU 6, Level 4 (101.26-101.16 m) & 27.05 & light gray chert \\
\hline TU 6, Level 10 (100.66-100.56 m) & 29.66 & $\begin{array}{l}\text { light yellowish brown chert with dark yellowish } \\
\text { brown cortex }\end{array}$ \\
\hline
\end{tabular}




\begin{tabular}{|c|c|c|}
\hline Provenience & $\begin{array}{c}\text { Maximum } \\
\text { Dimension } \\
\quad(\mathrm{mm})\end{array}$ & Material \\
\hline TU 6, Level 10 (100.66-100.56 m) & 29.60 & pale brown chert with brown cortex \\
\hline TU 6, Level 10 (100.66-100.56 m) & 24.83 & $\begin{array}{l}\text { yellowish brown chert with dark yellowish brown } \\
\text { cortex }\end{array}$ \\
\hline TU 6, Level 10 (100.66-100.56 m) & 21.17 & dark reddish gray chert \\
\hline TU 6, Level 11 (100.56-100.46 m) & 42.55 & $\begin{array}{l}\text { grayish brown and light gray chert with dark } \\
\text { yellowish brown cortex }\end{array}$ \\
\hline TU 6, Level $11(100.56-100.46 \mathrm{~m})$ & 40.59 & pale brown chert \\
\hline TU 6, Level 11 (100.56-100.46 m) & 37.41 & $\begin{array}{l}\text { grayish brown chert with very dark yellowish } \\
\text { brown cortex }\end{array}$ \\
\hline TU 6, Level $14(100.26-100.16 \mathrm{~m})$ & 42.84 & gray chert \\
\hline TU 7, Level 3 (101.36-101.26 m) & 21.73 & brown chert \\
\hline TU 7, Level 4 (101.26-101.16 m) & 24.20 & brown chert with dark yellowish brown cortex \\
\hline TU 7, Level 6 (101.06-100.96 m) & 40.64 & brown chert \\
\hline TU 7, Level 7 (100.96-100.86 m) & 51.49 & pale brown chert with dark yellowish brown cortex \\
\hline TU 7, Level 7 (100.96-100.86 m) & 31.40 & brown chert \\
\hline TU 7, Level 8 (100.86-100.76 m) & 31.91 & $\begin{array}{l}\text { dark reddish gray chert with dark reddish brown } \\
\text { cortex }\end{array}$ \\
\hline TU 7, Level 10 (100.66-100.56 m) & 43.28 & $\begin{array}{l}\text { light brownish gray chert with dark yellowish } \\
\text { brown cortex }\end{array}$ \\
\hline TU 7, Level 10 (100.66-100.56 m) & 37.26 & brown chert with yellowish brown cortex \\
\hline TU 7, Level 10 (100.66-100.56 m) & 17.27 & brownish yellow chert \\
\hline TU 7, Level 11 (100.56-100.46 m) & 57.19 & $\begin{array}{l}\text { brown and light yellowish brown chert with dark } \\
\text { yellowish brown cortex }\end{array}$ \\
\hline TU 7, Level 14 (100.26-100.16 m) & 21.40 & $\begin{array}{l}\text { very pale brown and yellowish brown chert with } \\
\text { dark yellowish brown cortex }\end{array}$ \\
\hline TU 8, Level 2 (101.48-101.38 m) & 38.21 & $\begin{array}{l}\text { grayish brown chert with dark yellowish brown } \\
\text { cortex }\end{array}$ \\
\hline TU 8, Level 3 (101.38-101.28 m) & 29.80 & pale brown chert with dark yellowish brown cortex \\
\hline TU 8, Level 11 (100.58-100.48 m) & 48.73 & $\begin{array}{l}\text { light yellowish brown chert with dark yellowish } \\
\text { brown cortex }\end{array}$ \\
\hline TU 8, Level $12(100.48-100.38 \mathrm{~m})$ & 33.18 & $\begin{array}{l}\text { light yellowish brown chert with dark yellowish } \\
\text { brown cortex }\end{array}$ \\
\hline TU 9, Level $2(101.46-101.36 \mathrm{~m})$ & 28.52 & pale brown chert with dark yellowish brown cortex \\
\hline TU 9, Level 5 (101.16-101.06 m) & 34.80 & $\begin{array}{l}\text { grayish brown chert with dark yellowish brown } \\
\text { cortex }\end{array}$ \\
\hline TU 9, Level 9 (100.76-100.66 m) & 29.74 & yellowish brown chalcedony \\
\hline TU 9, Level 10 (100.66-100.56 m) & 30.24 & pale brown chert with dark reddish brown cortex \\
\hline TU 9, Level 11 (100.56-100.46 m) & 29.88 & pale brown chert with dark yellowish brown cortex \\
\hline TU 10, Level 3 (101.36-101.26 m) & 20.20 & grayish brown chert \\
\hline TU 10, Level 4 (101.26-101.16 m) & 27.25 & pale brown chert \\
\hline TU 10, Level 4 (101.26-101.16 m) & 25.08 & light yellowish brown chert \\
\hline TU 10, Level 9 (100.76-100.66 m) & 29.26 & $\begin{array}{l}\text { brown chalcedony with dark yellowish brown } \\
\text { cortex }\end{array}$ \\
\hline TU 10, Level 10 (100.66-100.56 m) & 46.53 & $\begin{array}{l}\text { light yellowish brown chert with dark yellowish } \\
\text { brown cortex }\end{array}$ \\
\hline TU 10, Level $11(100.56-100.46 \mathrm{~m})$ & 24.90 & very pale brown chert \\
\hline TU 12, Level 9 (100.78-100.68 m) & 43.53 & pale brown chert with dark yellowish brown cortex \\
\hline TU 12. Level 9 (100.78-100.68 m) & 37.50 & dark reddish brown chert with pinkish grav cortex \\
\hline
\end{tabular}


single specimen of fine-grained quartzite and 2 of chalcedony, all are chert, with most being pieces of cobbles and pebbles with brownish and yellowish interiors and dark yellowish brown cortex. These materials likely were obtained locally from Brazos River gravels.

\section{Cores and Tested Cobbles}

Twenty-two cores and 5 tested cobbles were recovered (Table 4.5). They range in length from 25.25 to $127.37 \mathrm{~mm}$, in width from 18.80 to $74.40 \mathrm{~mm}$, and in thickness from 13.16 to $53.35 \mathrm{~mm}$, with average dimensions of $50 \times 38 \times 25 \mathrm{~mm}$. One is silicified wood, and the rest are chert cobbles in shades of yellow, brown, gray, and red; all probably were obtained locally from Brazos River gravels. Among the cores, most (77 percent) have multidirectional flake removals, with 18 percent having bidirectional removals, and a single specimen having unidirectional removals.

\section{Unmodified Debitage}

Almost 10,000 pieces of unmodified debitage $(n=9,872)$ were recovered. Given the inability to separate these into components, detailed analysis was considered unwarranted. A sample of 1,334 flakes (14 percent) from Test Units 6 and 7 was subjected to limited analysis to characterize the collection, however (Table 4.6). This analysis showed that the vast majority of the flakes (97 percent), are smaller than $31 \mathrm{~mm}$ in maximum dimension, and 71 percent lack cortex. Chert is the predominant raw material type, with quartzite and silicified wood represented minimally. The cherts occur in various shades of brown (including yellow), gray, and red, mirroring those observed in the cores and tested cobbles; hence, the vast majority appear to reflect materials procured locally from Brazos River gravels. These characteristics are quite similar to those of the unmodified debitage from the J. B. White site in Milam County, where similar gravels were procured from bars in the Little River and used to make mostly projectile points and knives (Gadus et al. 2006:93-95). Provenience information for the unmodified debitage can be found on Table 4.8.

\section{GROUND, BATTERED, AND STRIATED STONES}

Ten stone artifacts modified by grinding, battering, or striating were recovered (Table 4.7). Four are quartzite cobbles with battering, suggesting use as hammerstones, or grinding, suggesting use as manos; two show both kinds of modification. One small tabular fragment of sandstone has been ground on both faces, and one edge and may have been used as an abrader (Figure 4.4a). The remaining 5 items are pieces of ocher that are striated. While some of the striations could be the result of rodent gnawing, most appear to reflect human modification, either to create pigment or through use of these stones as abraders. Most are small fragments. The largest, weighing $175 \mathrm{~g}$, is a rectangular chunk with striations on multiple faces (Figure $4.4 \mathrm{~b})$.

\section{CERAMICS}

The ceramic sample is small, consisting of just nine sherds. Five are small, with maximum dimensions of $13.33-24.27 \mathrm{~mm}$. The other four are larger and range from 30.80 to $63.04 \mathrm{~mm}$ in size. They range from 4.62 to $6.26 \mathrm{~mm}$ in thickness. All have sandy pastes and lack visible temper such as grog and bone. Paste colors mostly are dark grayish brown to black, with one sherd having a yellowish brown exterior and black interior. All are undecorated sherds, and all but one are body sherds (Figure $4.5 \mathrm{a}-\mathrm{b}$ ). The single rim has a thinned and rounded lip (Figure 4.5c); the sherd is too small to determine rim orientation or vessel diameter. All nine sherds are consistent with the sandy paste wares found in Late Archaic and early Late Prehistoric contexts in east Texas. The sherds were recovered from the following proveniences: Level 4 of Test Unit 4, 102.03-101.93 m; Level 9 of Test Unit 5, 100.76-100.66 m; Level 9 of Test Unit 7, 100.76-100.66 m; Main Block, $99.91 \mathrm{~m}$ ( $\mathrm{n}=2)$; Main Block, $100.58 \mathrm{~m}(\mathrm{n}=3)$; and West Block, $100.25 \mathrm{~m}$. 
Table 4.5. Provenience and metric data for cores and tested cobbles

\begin{tabular}{|c|c|c|c|c|c|}
\hline Provenience & Material & $\begin{array}{l}\text { Direction of } \\
\text { Flake Scars }\end{array}$ & Length & Width & Thickness \\
\hline $\begin{array}{l}\text { TU 1, Level } 11 \\
(100.19-100.09 \mathrm{~m})\end{array}$ & $\begin{array}{l}\text { pale brown chert with yellowish } \\
\text { brown cortex }\end{array}$ & multidirectional & 43.99 & 35.19 & 23.87 \\
\hline $\begin{array}{l}\text { TU 2, Level } 17 \\
(99.96-99.86 \mathrm{~m})\end{array}$ & $\begin{array}{l}\text { pale brown chert with dark } \\
\text { yellowish brown cortex }\end{array}$ & tested cobble & 74.30 & 59.74 & 44.10 \\
\hline $\begin{array}{l}\text { TU 3, Level } 3 \\
(103.92-103.82 \mathrm{~m})\end{array}$ & $\begin{array}{l}\text { brown and very pale brown chert } \\
\text { with yellowish brown cortex }\end{array}$ & multidirectional & 29.28 & 29.08 & 20.46 \\
\hline $\begin{array}{l}\text { TU 3, Level } 4 \\
(103.82-103.72 \mathrm{~m})\end{array}$ & grayish brown chert & multidirectional & 30.55 & 23.37 & 13.16 \\
\hline $\begin{array}{l}\text { TU 3, Level } 5 \\
(103.72-103.62 \mathrm{~m})\end{array}$ & $\begin{array}{l}\text { light yellowish brown chert with } \\
\text { dark yellowish brown cortex }\end{array}$ & multidirectional & 45.72 & 35.32 & 19.67 \\
\hline $\begin{array}{l}\text { TU 4, Level } 5 \\
(101.93-101.83 \mathrm{~m})\end{array}$ & $\begin{array}{l}\text { pale brown chert with yellowish } \\
\text { brown cortex }\end{array}$ & multidirectional & 39.38 & 28.48 & 19.38 \\
\hline $\begin{array}{l}\text { TU 4, Level } 9 \\
(101.53-101.43 \mathrm{~m})\end{array}$ & $\begin{array}{l}\text { yellowish brown silicified wood } \\
\text { with yellowish brown cortex }\end{array}$ & tested cobble & 127.37 & 73.87 & 38.90 \\
\hline $\begin{array}{l}\text { TU 5, Level } 6 \\
(101.06-100.96 \mathrm{~m})\end{array}$ & $\begin{array}{l}\text { dark grayish brown chert with } \\
\text { dark yellowish brown cortex }\end{array}$ & bidirectional & 35.12 & 31.34 & 20.30 \\
\hline $\begin{array}{l}\text { TU 5, Level } 11 \\
(100.56-100.46 \mathrm{~m})\end{array}$ & $\begin{array}{l}\text { dark reddish brown chert with } \\
\text { dark reddish brown cortex }\end{array}$ & multidirectional & 40.68 & 30.51 & 21.26 \\
\hline $\begin{array}{l}\text { TU 5, Level } 12 \\
(100.46-100.36 \mathrm{~m})\end{array}$ & $\begin{array}{l}\text { pale brown and light brownish } \\
\text { gray chert with dark yellowish } \\
\text { brown cortex }\end{array}$ & multidirectional & 42.33 & 50.53 & 19.49 \\
\hline $\begin{array}{l}\text { TU 5, Level } 13 \\
(100.36-100.26 \mathrm{~m})\end{array}$ & $\begin{array}{l}\text { reddish brown chert with light } \\
\text { reddish brown cortex }\end{array}$ & multidirectional & 37.42 & 27.82 & 26.31 \\
\hline $\begin{array}{l}\text { TU 6, Level } 8 \\
(100.86-100.76 \mathrm{~m})\end{array}$ & $\begin{array}{l}\text { dark reddish brown chert with } \\
\text { dark reddish brown cortex }\end{array}$ & bidirectional & 49.26 & 27.71 & 18.52 \\
\hline $\begin{array}{l}\text { TU 6, Level } 8 \\
(100.86-100.76 \mathrm{~m})\end{array}$ & brown chert with brown cortex & bidirectional & 82.94 & 74.40 & 37.20 \\
\hline $\begin{array}{l}\text { TU 9, Level } 8 \\
(100.86-100.76 \mathrm{~m})\end{array}$ & $\begin{array}{l}\text { pale brown chert with dark } \\
\text { yellowish brown cortex }\end{array}$ & bidirectional & 44.22 & 31.68 & 15.87 \\
\hline $\begin{array}{l}\text { TU 9, Level } 9 \\
(100.76-100.66 \mathrm{~m})\end{array}$ & $\begin{array}{l}\text { light brownish gray chert with } \\
\text { dark yellowish brown cortex }\end{array}$ & tested cobble & 35.12 & 31.60 & 28.75 \\
\hline $\begin{array}{l}\text { TU 9, Level } 14 \\
(100.26-100.16 \mathrm{~m})\end{array}$ & $\begin{array}{l}\text { brown chert with dark yellowish } \\
\text { brown cortex }\end{array}$ & multidirectional & 25.25 & 18.80 & 17.31 \\
\hline $\begin{array}{l}\text { TU 10, Level } 11 \\
(100.56-100.46 \mathrm{~m})\end{array}$ & $\begin{array}{l}\text { light yellowish brown chert with } \\
\text { yellowish brown cortex }\end{array}$ & multidirectional & 44.11 & 28.08 & 19.73 \\
\hline $\begin{array}{l}\text { TU 10, Level } 11 \\
(100.56-100.46 \mathrm{~m})\end{array}$ & $\begin{array}{l}\text { light gray chert with yellowish } \\
\text { brown cortex }\end{array}$ & multidirectional & 44.88 & 27.24 & 24.49 \\
\hline $\begin{array}{l}\text { TU 10, Level } 12 \\
(100.46-100.36 \mathrm{~m})\end{array}$ & $\begin{array}{l}\text { pale brown chert with dark } \\
\text { yellowish brown cortex }\end{array}$ & tested cobble & 86.88 & 52.64 & 33.47 \\
\hline $\begin{array}{l}\text { TU 11, Level } 7 \\
(100.97-100.87 \mathrm{~m})\end{array}$ & $\begin{array}{l}\text { very pale brown chert with dark } \\
\text { yellowish brown cortex }\end{array}$ & multidirectional & 54.84 & 54.00 & 22.87 \\
\hline $\begin{array}{l}\text { TU 11. Level } 9 \\
(100.77-100.67 \mathrm{~m})\end{array}$ & $\begin{array}{l}\text { dark grayish brown chert with } \\
\text { dark yellowish brown cortex }\end{array}$ & multidirectional & 62.04 & 48.96 & 36.06 \\
\hline $\begin{array}{l}\text { TU 11, Level } 10 \\
(100.67-100.57 \mathrm{~m})\end{array}$ & $\begin{array}{l}\text { pale brown chert with reddish } \\
\text { brown cortex }\end{array}$ & multidirectional & 39.31 & 30.00 & 18.12 \\
\hline $\begin{array}{l}\text { TU 11, Level } 10 \\
(100.67-100.57 \mathrm{~m})\end{array}$ & $\begin{array}{l}\text { very pale brown chert with dark } \\
\text { yellowish brown cortex }\end{array}$ & multidirectional & 33.14 & 24.58 & 14.66 \\
\hline $\begin{array}{l}\text { TU 11, Level } 11 \\
(100.57-100.47 \mathrm{~m})\end{array}$ & $\begin{array}{l}\text { grayish brown chert with dark } \\
\text { yellowish brown cortex }\end{array}$ & unidirectional & 86.23 & 65.29 & 53.35 \\
\hline $\begin{array}{l}\text { TU 11, Level } 13 \\
(100.37-100.27 \mathrm{~m})\end{array}$ & $\begin{array}{l}\text { very pale brown chert with dark } \\
\text { yellowish brown cortex }\end{array}$ & multidirectional & 35.48 & 19.37 & 19.15 \\
\hline
\end{tabular}


Table 4.5, continued

\begin{tabular}{l|l|l|c|c|c}
\hline \multicolumn{1}{c|}{ Provenience } & \multicolumn{1}{|c|}{ Material } & $\begin{array}{c}\text { Direction of } \\
\text { Flake Scars }\end{array}$ & Length & Width & Thickness \\
\hline $\begin{array}{l}\text { TU 12, Level 6 } \\
(101.08-100.98 \mathrm{~m})\end{array}$ & $\begin{array}{l}\text { dark reddish brown chert with } \\
\text { dark reddish brown cortex }\end{array}$ & tested cobble & 28.48 & 26.49 & 20.66 \\
\hline $\begin{array}{l}\text { Feature 2 }(100.55- \\
100.43 \mathrm{~m})\end{array}$ & $\begin{array}{l}\text { dark gray chert with dark } \\
\text { yellowish brown cortex }\end{array}$ & multidirectional & 46.48 & 34.27 & 26.10 \\
\hline
\end{tabular}

Note: All measurements are in millimeters.

Table 4.6. Unmodified debitage characteristics

\begin{tabular}{l|l|l}
\hline Size: & No. & $\%$ \\
\hline $0-10 \mathrm{~mm}$ & 188 & 14.1 \\
\hline $11-30 \mathrm{~mm}$ & 1,110 & 83.2 \\
\hline $31-50 \mathrm{~mm}$ & 35 & 2.6 \\
\hline $50+\mathrm{mm}$ & 1 & 0.3 \\
\hline Total & 1,334 & \\
\hline Cortex: & & \\
\hline Yes & 390 & 29.2 \\
\hline No & 944 & 70.8 \\
\hline Total & 1,334 & \\
\hline
\end{tabular}

Raw Material:

\begin{tabular}{l|l|l}
\hline Chert & 1,262 & 94.6 \\
\hline Quartzite & 14 & 1.0 \\
\hline Silicified Wood & 58 & 4.3 \\
\hline Total & 1,334 & \\
\hline
\end{tabular}

Color:

\begin{tabular}{l|l|l}
\hline Browns & 614 & 46.0 \\
\hline Grays & 313 & 23.5 \\
\hline Reds & 400 & 30.0 \\
\hline Other (White, Translucent) & 7 & 0.5 \\
\hline Total & 1,334 & \\
\hline
\end{tabular}

\section{OTHER MATERIALS}

\section{Burned Rocks}

Burned rocks totaling $5.0 \mathrm{~kg}(\mathrm{n}=642)$ were documented and discarded. They mostly were stream-rolled cobbles and pebbles of a variety of materials, including chert, quartzite, and silicified wood, with some sandstone also present. Most of these materials likely were obtained from nearby exposed gravel bars. They were found scattered throughout the site deposits rather than as discrete features. They

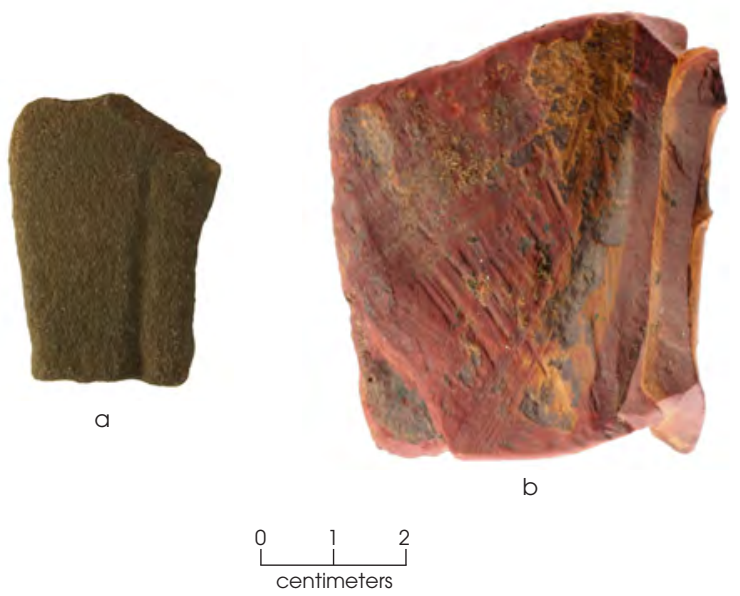

Figure 4.4. Ground sandstone abrader (a) and striated ocher (b).

may represent disturbed rock hearths, discarded boiling stones, and detritus from heating chert for production of chipped stone tools. Table 4.8 provides provenience information for the burned rocks.

\section{Possibly Flaked Silicified Wood}

Seventy-five pieces of silicified wood from 39 proveniences may be flaked, but because of the poor quality of the material and the angularity of the breaks, it is hard to be certain (see Table 4.8). Most probably could be classified as 
Table 4.7. Provenience and metric data for ground, battered, and striated stones

\begin{tabular}{c|l|l|c|c|c|c}
\hline \multicolumn{1}{c|}{ Provenience } & \multicolumn{1}{c|}{ Tool Type } & Completeness & Length & Width & Thickness & Weight \\
\hline $\begin{array}{c}\text { TU 9, Level 1 } \\
(101.55-101.46 \mathrm{~m})\end{array}$ & $\begin{array}{l}\text { quartzite } \\
\text { hammerstone }\end{array}$ & fragment & - & - & - & 29.3 \\
\hline $\begin{array}{c}\text { TU 9, Level 5 } \\
(101.16-101.06 \mathrm{~m})\end{array}$ & $\begin{array}{l}\text { quartzite mano } \\
\text { and } \\
\text { hammerstone }\end{array}$ & complete & 54.91 & 48.26 & 34.43 & 137.3 \\
\hline $\begin{array}{c}\text { TU 10, Level 4 } \\
(101.26-101.16 \mathrm{~m})\end{array}$ & $\begin{array}{l}\text { quartzite mano } \\
\text { and } \\
\text { hammerstone }\end{array}$ & complete & 48.13 & 39.60 & 29.41 & 80.9 \\
\hline $\begin{array}{c}\text { TU 12, Level 1B } \\
(101.58-101.48 \mathrm{~m})\end{array}$ & $\begin{array}{l}\text { quartzite } \\
\text { hammerstone }\end{array}$ & fragment & - & 51.37 & 32.64 & 100.7 \\
\hline $\begin{array}{c}\text { TU 6, Level 8 } \\
(100.86-100.76 \mathrm{~m})\end{array}$ & $\begin{array}{l}\text { sandstone } \\
\text { abrader }\end{array}$ & fragment & 38.19 & 26.96 & 13.41 & 10.8 \\
\hline $\begin{array}{c}\text { TU 6, Level 10 } \\
(100.66-100.56 \mathrm{~m})\end{array}$ & $\begin{array}{l}\text { striated ocher } \\
\text { TU 10, Level 8 } \\
(100.86-100.76 \mathrm{~m})\end{array}$ & striagment & 28.67 & 16.35 & 3.46 & 2.6 \\
\hline $\begin{array}{c}\text { TU 10, Level 10 } \\
(100.66-100.56 \mathrm{~m})\end{array}$ & striated ocher & fragment & 10.60 & 9.58 & 5.30 & 0.5 \\
\hline $\begin{array}{c}\text { TU 10, Level 12 } \\
(100.46-100.36 \mathrm{~m})\end{array}$ & striated ocher & complete & 81.9 & 51.39 & 43.34 & 175.0 \\
\hline $\begin{array}{c}\text { TU 11, Level 12 } \\
(100.52-100.42 \mathrm{~m})\end{array}$ & striated ocher & complete & 42.40 & 32.27 & 18.08 & 24.5 \\
\hline
\end{tabular}

Note: All measurements are in millimeters. Weight is in grams.

unmodified debitage, although some could be cores or even tools.

\section{Burned Clay}

Burned clay was quite abundant, totaling ca. $16.5 \mathrm{~kg}$. The vast majority of these are small chunks less than 1-2 $\mathrm{cm}$ across, lacking any notable characteristics, though pieces $4-5 \mathrm{~cm}$ in diameter are not uncommon. At least four pieces have stick impressions and appear to be wattleimpressed daub (Figure 4.6). If so, they imply that at least some of the burned clay represents structural remains. Burned clay was most common in the lower levels of the site (see Table 4.8), but it did not occur in sufficient concentrations to be recorded as features. Most was documented and discarded, with only a sample retained.

\section{Vertebrate and Invertebrate Faunal Remains}

Faunal remains consisting of 105 pieces of animal bone and mussel shells, weighing just $18.8 \mathrm{~g}$, were recovered from 48 proveniences (see Table 4.8). Most are very fragmented and unidentifiable, though a few fish vertebrae and turtle shell fragments are present. A single modified bone recovered is the $1.0-\mathrm{cm}$-long distal tip of a bone needle, but it is too small to discern anything else about it.

\section{Charcoal}

Charcoal was collected from just 20 proveniences, with most coming from the screens rather than in situ samples (see Table 4.8). Most samples are quite small, with the collection totaling just $12.3 \mathrm{~g}$. Most pieces are from the upper levels of the excavations and thus may be recent intrusions rather than relating to the prehistoric occupations. Three samples taken from Levels 7 through 15 were submitted for radiocarbon dating, however (see Chapter 5).

\section{Historic Artifacts}

A small collection of household and architectural artifacts $(\mathrm{n}=6)$ relates to historic use of the site: two nails, two pieces of glass, one 

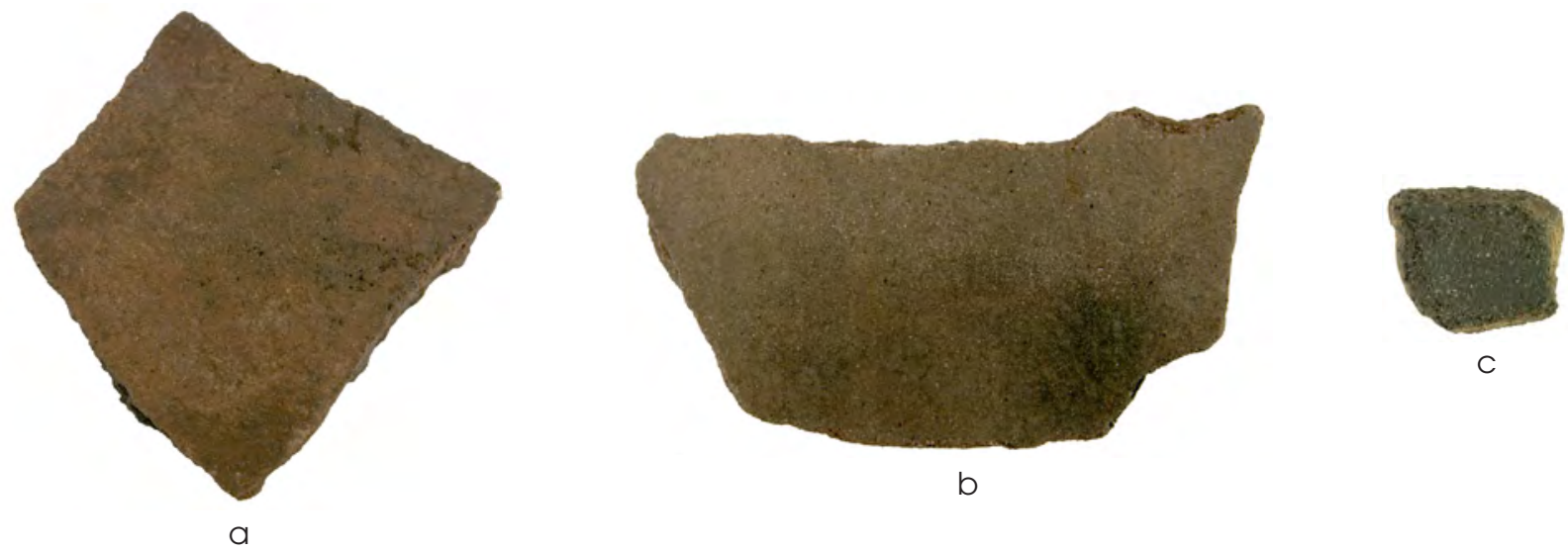

Figure 4.5. Prehistoric ceramic sherds. (a-b) Body sherds; (c) rim sherd.
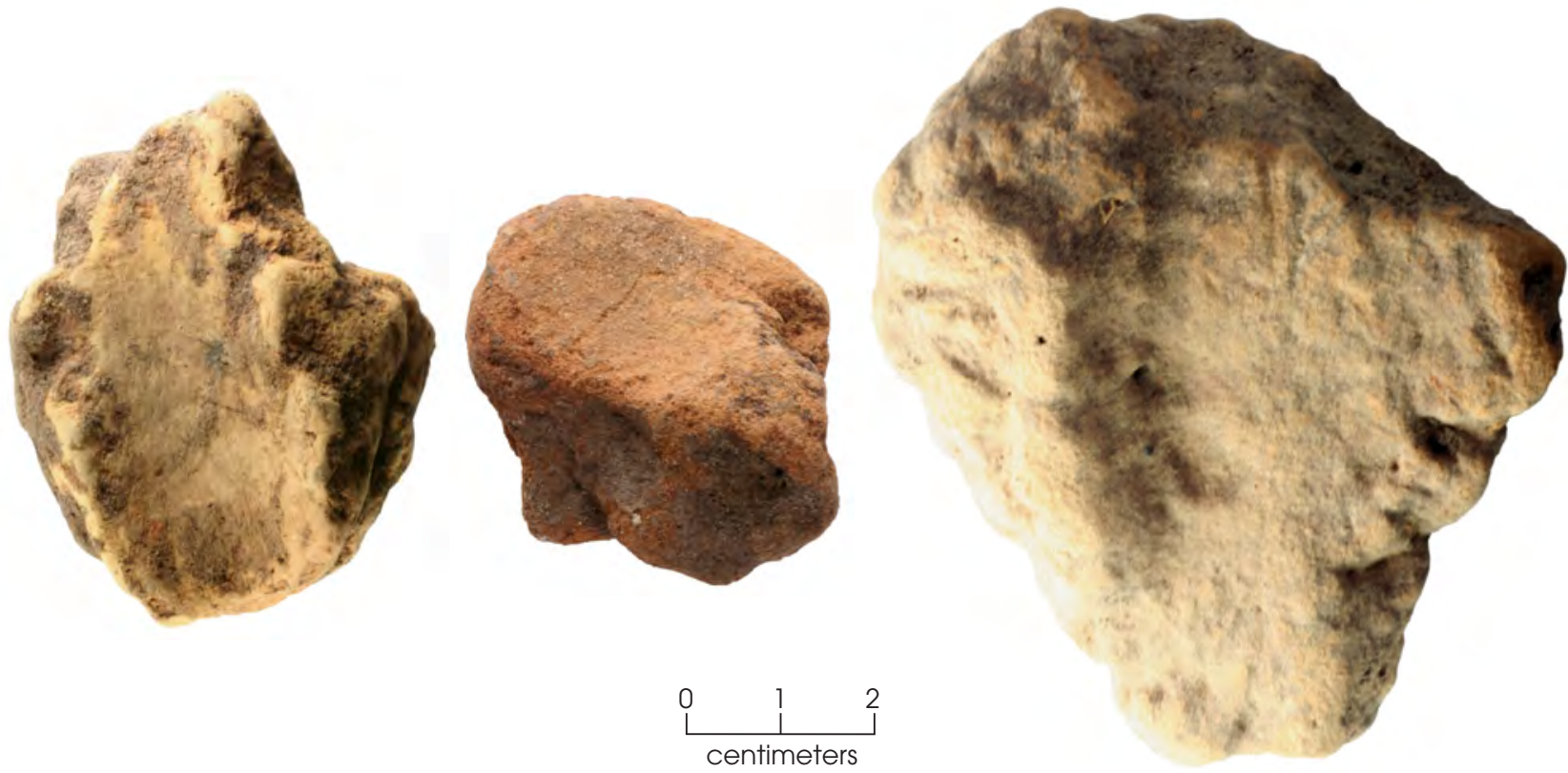

Figure 4.6. Burned clay with impressions. 
Table 4.8. Provenience data for other materials and unmodified debitage

\begin{tabular}{|c|c|c|c|c|c|c|c|c|}
\hline TU & Level & Elevation (m) & $\begin{array}{c}\text { Burned } \\
\text { Rocks (g) }\end{array}$ & $\begin{array}{c}\text { Flaked(?) } \\
\text { Silicified } \\
\text { Wood }\end{array}$ & $\begin{array}{l}\text { Burned } \\
\text { Clay (g) }\end{array}$ & $\begin{array}{c}\text { Faunal } \\
\text { Remains } \\
(\mathrm{g})\end{array}$ & $\begin{array}{c}\text { Charcoal } \\
(\mathrm{g})\end{array}$ & $\begin{array}{l}\text { Unmodified } \\
\text { Debitage }\end{array}$ \\
\hline 1 & 1 & 101.19-101.09 & & & & & & 1 \\
\hline 1 & 2 & 101.09-100.99 & & & & & 0.6 & 60 \\
\hline 1 & 3 & $100.99-100.89$ & 3.6 & & & & 1.4 & 126 \\
\hline 1 & 4 & $100.89-100.79$ & 1.9 & & & 0.2 & 2.5 & 96 \\
\hline 1 & 5 & $100.79-100.69$ & 3.7 & & & & 4.4 & 77 \\
\hline 1 & 6 & $100.69-100.59$ & 36.4 & & 20.6 & & 0.1 & 119 \\
\hline 1 & 7 & $100.59-100.49$ & 19.5 & & 96.1 & 0.5 & & 70 \\
\hline 1 & 8 & $100.49-100.39$ & 115.4 & & 357.3 & 0.2 & & 74 \\
\hline 1 & 9 & 100.39-100.29 & 10.4 & & 149.9 & & & 42 \\
\hline 1 & 10 & \begin{tabular}{|l|}
$100.29-100.19$ \\
\end{tabular} & 2.0 & & 158.4 & & & 21 \\
\hline 1 & 11 & \begin{tabular}{|l|}
$100.19-100.09$ \\
\end{tabular} & 72.2 & & 184.5 & & & 20 \\
\hline 2 & 1 & 101.56-101.46 & & 1 & 3.4 & & & 0 \\
\hline 2 & 2 & $101.46-101.36$ & 4.1 & & & & & 43 \\
\hline 2 & 3 & $101.36-101.26$ & 3.5 & 1 & & & & 108 \\
\hline 2 & 4 & $101.26-101.16$ & 0.1 & & 47.6 & & & 93 \\
\hline 2 & 5 & 101.16-101.06 & 0.1 & & 2.6 & & & 60 \\
\hline 2 & 6 & $101.06-100.96$ & 9.9 & & 48.6 & 0.3 & $<0.1$ & 94 \\
\hline 2 & 7 & $100.96-100.86$ & 7.2 & 3 & 88.7 & 0.1 & & 86 \\
\hline 2 & 8 & $100.86-100.76$ & 42.9 & & 37.2 & & & 73 \\
\hline 2 & 9 & $100.76-100.66$ & 64.0 & & 114.5 & & & 79 \\
\hline 2 & 10 & $100.66-100.56$ & 27.2 & 2 & 97.5 & & & 78 \\
\hline 2 & 11 & 100.56-100.46 & 82.1 & 1 & 83.3 & 0.1 & & 47 \\
\hline 2 & 12 & 100.46-100.36 & 114.9 & & 383.1 & & & 42 \\
\hline 2 & 13 & $100.36-100.26$ & 203.3 & & 387.2 & $<0.1$ & & 100 \\
\hline 2 & 14 & $100.26-100.16$ & 230.2 & & 300.9 & 0.3 & & 61 \\
\hline 2 & 15 & $100.16-100.06$ & 160.4 & & 248.8 & 0.2 & & 71 \\
\hline 2 & 16 & $100.06-99.96$ & 231.7 & & 223.9 & & & 61 \\
\hline 2 & 17 & 99.96-99.86 & & & 493.8 & & & 37 \\
\hline 3 & 1 & $104.21-104.11$ & & & & & & 3 \\
\hline 3 & 2 & 104.11-104.01 & 12.6 & 1 & & & & 128 \\
\hline 3 & 3 & $104.01-103.91$ & & 2 & 86.4 & 1.4 & & 120 \\
\hline 3 & 4 & 103.91-103.81 & 71.1 & 2 & 505.4 & & & 124 \\
\hline 3 & 5 & 103.81-103.71 & 173.9 & & 863.3 & & & 55 \\
\hline 3 & 6 & 103.71-103.61 & & & 141.3 & & & 5 \\
\hline 4 & 1 & 102.33-102.23 & & & & & & 2 \\
\hline 4 & 2 & $102.23-102.13$ & & 1 & & & & 25 \\
\hline 4 & 3 & $102.13-102.03$ & 1.0 & & 3.0 & & & 52 \\
\hline 4 & 4 & $102.03-101.93$ & & & & & $<0.1$ & 41 \\
\hline 4 & 5 & 101.93-101.83 & 12.7 & 2 & 33.1 & & & 40 \\
\hline 4 & 6 & $101.83-101.73$ & 7.6 & & 6.3 & & & 49 \\
\hline 4 & 7 & $101.73-101.63$ & 74.3 & 2 & 19.1 & & & 65 \\
\hline 4 & 8 & $101.63-101.53$ & 125.0 & & 60.4 & & & 31 \\
\hline 4 & 9 & $101.53-101.43$ & 45.3 & & 84.0 & & & 14 \\
\hline 4 & 10 & $101.43-101.33$ & 45.0 & & 6.8 & & & 7 \\
\hline
\end{tabular}


Table 4.8, continued

\begin{tabular}{|c|c|c|c|c|c|c|c|c|}
\hline $\mathrm{TU}$ & Level & Elevation $(\mathrm{m})$ & \begin{tabular}{|c|} 
Burned \\
Rocks (g) \\
\end{tabular} & \begin{tabular}{|c|} 
Flaked(?) \\
Silicified \\
Wood \\
\end{tabular} & $\begin{array}{l}\text { Burned } \\
\text { Clay (g) }\end{array}$ & $\begin{array}{c}\text { Faunal } \\
\text { Remains } \\
(\mathrm{g})\end{array}$ & $\begin{array}{c}\text { Charcoal } \\
(\mathrm{g})\end{array}$ & $\begin{array}{c}\text { Unmodified } \\
\text { Debitage }\end{array}$ \\
\hline 5 & 1 & $101.56-101.46$ & & & & & & 19 \\
\hline 5 & 2 & $101.46-101.36$ & 5.8 & & & & & 98 \\
\hline 5 & 3 & $101.36-101.26$ & 13.9 & & & & & 81 \\
\hline 5 & 4 & $101.26-101.16$ & 4.7 & & 3.6 & 0.8 & & 113 \\
\hline 5 & 5 & $101.16-101.06$ & & & 136.3 & 0.2 & & 126 \\
\hline 5 & 6 & $101.06-100.96$ & 14.4 & & 22.6 & 0.2 & & 66 \\
\hline 5 & 7 & $100.96-100.86$ & & & 183.9 & & & 75 \\
\hline 5 & 8 & $100.86-100.76$ & 19.0 & & 94.4 & & & 79 \\
\hline 5 & 9 & $100.76-100.66$ & 47.8 & 3 & 79.3 & & & 91 \\
\hline 5 & 10 & $100.66-100.56$ & 70.2 & 1 & 254.6 & 0.7 & & 64 \\
\hline 5 & 11 & $100.56-100.46$ & 2.8 & & 240.6 & & & 60 \\
\hline 5 & 12 & $100.46-100.36$ & 42.8 & & 339.2 & & & 38 \\
\hline 5 & 13 & $100.36-100.26$ & 74.9 & & 191.3 & & & 21 \\
\hline 5 & 14 & $100.26-100.16$ & 39.6 & & 204.5 & & & 49 \\
\hline 5 & 15 & $100.16-100.06$ & 56.0 & & 300.3 & 0.6 & & 46 \\
\hline 6 & $1 \mathrm{~A}$ & $101.66-101.56$ & & & & & & 11 \\
\hline 6 & $1 \mathrm{~B}$ & $101.56-101.46$ & & & & & & 76 \\
\hline 6 & 2 & $101.46-101.36$ & 6.0 & & & & & 47 \\
\hline 6 & 3 & $101.36-101.26$ & 1.7 & 2 & & & & 70 \\
\hline 6 & 4 & $101.26-101.16$ & & & & & & 89 \\
\hline 6 & 5 & $101.16-101.06$ & 0.9 & & & & & 90 \\
\hline 6 & 6 & 101.06-100.96 & 5.6 & & 22.2 & 0.1 & & 80 \\
\hline 6 & 7 & $100.96-100.86$ & 9.7 & & 18.4 & 0.2 & $<0.1$ & 76 \\
\hline 6 & 8 & $100.86-100.76$ & 21.9 & & 45.6 & & & 101 \\
\hline 6 & 9 & $100.76-100.66$ & 17.8 & & 115.1 & 0.2 & & 80 \\
\hline 6 & 10 & $100.66-100.56$ & 74.0 & 3 & 265.8 & 1.5 & & 93 \\
\hline 6 & 11 & $100.56-100.46$ & 59.1 & 1 & 280.2 & & & 80 \\
\hline 6 & 12 & $100.46-100.36$ & 23.4 & & 203.0 & & & 28 \\
\hline 6 & 13 & $100.36-100.26$ & 15.8 & & 173.9 & 0.5 & & 33 \\
\hline 6 & 14 & $100.26-100.16$ & 72.0 & & 119.0 & 0.3 & & 37 \\
\hline 7 & 1 & $101.62-101.46$ & 0.3 & & 5.5 & & & 54 \\
\hline 7 & 2 & $101.46-101.36$ & 7.6 & & 22.5 & & & 83 \\
\hline 7 & 3 & $101.36-101.26$ & 0.6 & & 12.2 & & & 58 \\
\hline 7 & 4 & $101.26-101.16$ & & & & & $<0.1$ & 86 \\
\hline 7 & 5 & $101.16-101.06$ & 2.9 & & 19.8 & $<0.1$ & & 76 \\
\hline 7 & 6 & $101.06-100.96$ & 19.3 & & 106.7 & 0.1 & & 116 \\
\hline 7 & 7 & $100.96-100.86$ & 32.6 & & 38.6 & & & 83 \\
\hline 7 & 8 & $100.86-100.76$ & 11.3 & & 56.0 & & & 88 \\
\hline 7 & 9 & $100.76-100.66$ & 58.8 & 1 & 86.9 & 0.1 & & 65 \\
\hline 7 & 10 & $100.66-100.56$ & 104.6 & 2 & 116.2 & 0.3 & & 83 \\
\hline 7 & 11 & $100.56-100.46$ & 252.8 & 1 & 199.3 & 0.1 & & 79 \\
\hline 7 & 12 & $100.46-100.36$ & 230.6 & & 128.4 & & & 48 \\
\hline 7 & 13 & $100.36-100.26$ & 40.3 & & 79.2 & & & 32 \\
\hline
\end{tabular}




\begin{tabular}{|c|c|c|c|c|c|c|c|c|}
\hline $\mathrm{TU}$ & Level & Elevation $(\mathrm{m})$ & \begin{tabular}{|c|} 
Burned \\
Rocks (g) \\
\end{tabular} & \begin{tabular}{|c|} 
Flaked(?) \\
Silicified \\
Wood \\
\end{tabular} & $\begin{array}{l}\text { Burned } \\
\text { Clay (g) }\end{array}$ & $\begin{array}{c}\text { Faunal } \\
\text { Remains } \\
(\mathrm{g})\end{array}$ & $\begin{array}{c}\text { Charcoal } \\
(\mathrm{g})\end{array}$ & $\begin{array}{c}\text { Unmodified } \\
\text { Debitage }\end{array}$ \\
\hline 7 & 14 & $100.26-100.16$ & 9.5 & & 41.6 & & & 32 \\
\hline 8 & 1 & $101.58-101.48$ & & & & & & 7 \\
\hline 8 & 2 & $101.48-101.38$ & 2.9 & & & & & 59 \\
\hline 8 & 3 & $101.38-101.28$ & 1.2 & & & & & 79 \\
\hline 8 & 4 & $101.28-101.18$ & & & 8.3 & & & 63 \\
\hline 8 & 5 & $101.18-101.08$ & 0.8 & & 5.0 & & & 73 \\
\hline 8 & 6 & $101.08-100.98$ & 2.6 & & & 0.1 & 0.1 & 56 \\
\hline 8 & 7 & $100.98-100.88$ & 8.7 & & 14.3 & 0.6 & & 88 \\
\hline 8 & 8 & $100.88-100.78$ & 82.9 & & 34.1 & 0.4 & & 68 \\
\hline 8 & 9 & $100.78-100.68$ & 1.8 & & 35.9 & $<0.1$ & & 45 \\
\hline 8 & 10 & $100.68-100.58$ & 44.4 & 4 & 195.3 & 1.0 & & 61 \\
\hline 8 & 11 & $100.58-100.48$ & 42.0 & 2 & 195.3 & 3.3 & & 57 \\
\hline 8 & 12 & $100.48-100.38$ & 136.4 & & 315.8 & 0.1 & & 77 \\
\hline 8 & 13 & $100.38-100.28$ & 30.8 & & 80.4 & & & 45 \\
\hline 8 & 14 & $100.28-100.18$ & 12.0 & & 95.2 & & & 17 \\
\hline 9 & 1 & $101.55-101.46$ & 2.9 & & & & & 4 \\
\hline 9 & 2 & $101.46-101.36$ & 0.8 & & & & & 63 \\
\hline 9 & 3 & $101.36-101.26$ & 6.3 & 1 & & 0.2 & & 96 \\
\hline 9 & 4 & $101.26-101.16$ & 0.7 & & 304.5 & 0.4 & & 78 \\
\hline 9 & 5 & $101.16-101.06$ & 1.2 & & 121.3 & 0.1 & & 63 \\
\hline 9 & 6 & $101.06-100.96$ & 1.7 & & 16.0 & & & 56 \\
\hline 9 & 7 & $100.96-100.86$ & & & 20.5 & & 0.1 & 67 \\
\hline 9 & 8 & $100.86-100.76$ & 1.6 & & 79.4 & & & 63 \\
\hline 9 & 9 & $100.76-100.66$ & 57.2 & 4 & 175.9 & & & 103 \\
\hline 9 & 10 & $100.66-100.56$ & 28.3 & 6 & 153.7 & & & 89 \\
\hline 9 & 11 & $100.56-100.46$ & 13.2 & 1 & 138.2 & 0.1 & & 63 \\
\hline 9 & 12 & $100.46-100.36$ & 60.5 & 2 & 157.7 & 0.8 & & 56 \\
\hline 10 & 1 & $101.63-101.46$ & 1.8 & & & & & 57 \\
\hline 10 & 2 & $101.46-101.36$ & 2.4 & 3 & 37.8 & 0.3 & 0.2 & 78 \\
\hline 10 & 3 & $101.36-101.26$ & 0.3 & 1 & 8.3 & & 0.1 & 73 \\
\hline 10 & 4 & $101.26-101.16$ & 1.2 & & 270.1 & & & 79 \\
\hline 10 & 5 & $101.16-101.06$ & & 2 & 37.5 & & & 75 \\
\hline 10 & 6 & $101.06-100.96$ & & 2 & 28.7 & & & 59 \\
\hline 10 & 7 & $100.96-100.86$ & 22.5 & & 40.5 & & & 66 \\
\hline 10 & 8 & $100.86-100.76$ & 8.5 & 5 & 65.8 & & & 89 \\
\hline 10 & 9 & $100.76-100.66$ & 5.2 & 1 & 100.6 & 0.1 & & 76 \\
\hline 10 & 10 & $100.66-100.56$ & & & 376.8 & & 0.2 & 58 \\
\hline 10 & 11 & $100.56-100.46$ & 198.8 & & 272.0 & & & 62 \\
\hline 10 & 12 & $100.46-100.36$ & 45.0 & & 167.2 & & & 44 \\
\hline 11 & $1 \mathrm{~A}$ & $101.72-101.62$ & & & 4.3 & & & 56 \\
\hline 11 & 1B & $101.62-101.52$ & 2.6 & 1 & 5.5 & & & 102 \\
\hline 11 & 2 & $101.52-101.42$ & 3.5 & & 6.0 & & & 85 \\
\hline 11 & 3 & $101.42-101.32$ & 30.7 & & 16.8 & & & 68 \\
\hline
\end{tabular}


Table 4.8, continued

\begin{tabular}{|c|c|c|c|c|c|c|c|c|}
\hline TU & Level & Elevation $(\mathrm{m})$ & $\begin{array}{c}\text { Burned } \\
\text { Rocks (g) }\end{array}$ & $\begin{array}{c}\text { Flaked(?) } \\
\text { Silicified } \\
\text { Wood } \\
\end{array}$ & $\begin{array}{l}\text { Burned } \\
\text { Clay (g) }\end{array}$ & $\begin{array}{c}\text { Faunal } \\
\text { Remains } \\
(\mathrm{g})\end{array}$ & $\begin{array}{c}\text { Charcoal } \\
(\mathrm{g})\end{array}$ & $\begin{array}{c}\text { Unmodified } \\
\text { Debitage }\end{array}$ \\
\hline 11 & 4 & $101.32-101.22$ & & & 11.8 & & & 80 \\
\hline 11 & 5 & $101.22-101.12$ & & & 24.1 & & & 82 \\
\hline 11 & 6 & 101.12-101.02 & & & 111.4 & 0.5 & & 76 \\
\hline 11 & 7 & 101.02-100.92 & 4.8 & 2 & 155.9 & 0.1 & & 74 \\
\hline 11 & 8 & $100.92-100.82$ & 43.2 & & 109.2 & 0.7 & & 74 \\
\hline 11 & 9 & $100.82-100.72$ & 46.9 & & 217.5 & & & 70 \\
\hline 11 & 10 & $100.72-100.62$ & 148.1 & 1 & 455.6 & & & 99 \\
\hline 11 & 11 & $100.62-100.52$ & 85.9 & & 393.2 & & & 35 \\
\hline 11 & 12 & $100.52-100.42$ & 50.4 & & 235.8 & & & 45 \\
\hline 11 & 13 & $100.42-100.32$ & & & 75.7 & & & \\
\hline 12 & $1 \mathrm{~A}$ & $101.72-101.58$ & 1.9 & & 9.0 & & & 83 \\
\hline 12 & $1 \mathrm{~B}$ & $101.58-101.48$ & & & 50.3 & & 0.9 & 100 \\
\hline 12 & 2 & $101.48-101.38$ & 7.1 & & 6.7 & & 0.4 & 55 \\
\hline 12 & 3 & $101.38-101.28$ & 1.0 & 1 & 14.4 & 0.4 & 1.1 & 69 \\
\hline 12 & 4 & $101.28-101.18$ & 9.4 & 2 & 69.0 & & & 78 \\
\hline 12 & 5 & 101.18-101.08 & 4.4 & & 150.6 & $<0.1$ & $<0.1$ & 65 \\
\hline 12 & 6 & 101.08-100.98 & 55.0 & & 136.1 & $<0.1$ & 0.2 & 87 \\
\hline 12 & 7 & $100.98-100.88$ & 10.5 & & 121.3 & 0.2 & $<0.1$ & 66 \\
\hline 12 & 8 & $100.88-100.78$ & 8.6 & 1 & 145.2 & 0.2 & & 65 \\
\hline 12 & 9 & $100.78-100.68$ & 21.9 & & 195.0 & & & 54 \\
\hline 12 & 10 & $100.68-100.58$ & 18.6 & & 223.4 & & & 60 \\
\hline 12 & 11 & $100.58-100.48$ & 99.0 & & 171.2 & & & 48 \\
\hline 12 & 12 & $100.48-100.38$ & 11.4 & 1 & 104.0 & & & 19 \\
\hline 12 & 13 & $100.38-100.28$ & 32.0 & & 76.3 & & & 16 \\
\hline Feature 1 & & $101.33-100.93$ & 2.3 & & 57.9 & & & 19 \\
\hline Feature 1 & & $101.33-100.93$ & 5.2 & & & & & 3 \\
\hline Burial 1 & & $100.55-100.43$ & 16.5 & & 69.1 & & & 12 \\
\hline Burial 2 & & 100.63 & & & & & & 15 \\
\hline Total & & & $5,033.7$ & 75 & $16,518.1$ & 18.8 & 12.3 & 9,872 \\
\hline
\end{tabular}

ceramic sherd, and one button. Both nails are wire nails. Both pieces of glass are clear and thin. The sherd is a piece of undecorated whiteware, probably not a plate based on the curvature. The button is flat metal. All but one of these artifacts are from Levels 2 and 3 of Test Unit 3 on the ridge crest south of the borrow pit; the other is from the uppermost level of Test Unit 12. According to the landowner, a sharecropper's house once sat in the vicinity of Test Unit 3, and this appears to be the source of this light scatter of historic artifacts. 


\section{CONCLUSIONS}

\section{DISTRIBUTIONS AND CHRONOLOGY}

Cultural materials were abundant in all of the test units, indicating substantial occupation of all parts of the site within the current project area. Based on the most-abundant artifact class (lithics), it appears that the area of the manual block excavation (Test Units 2 and 5-12) was used most intensively. The density of lithic artifacts here is 943 items $/ \mathrm{m}^{2}$, compared with $713 / \mathrm{m}^{2}$ in Test Unit $1,439 / \mathrm{m}^{2}$ in Test Unit 3 , and $332 / \mathrm{m}^{2}$ in Test Unit 4 . Burned rocks also were most abundant in the manual block excavation. Burned clay was more abundant in the block $\left(1,513 \mathrm{~g} / \mathrm{m}^{2}\right)$ than Test Units 1 and $4\left(967 \mathrm{~g} / \mathrm{m}^{2}\right.$ and $\left.213 \mathrm{~g} / \mathrm{m}^{2}\right)$, but it was most frequent in Test Unit $3\left(1,596 \mathrm{~g} / \mathrm{m}^{2}\right)$.

Vertical distributions are best examined by area. In Test Unit 3, on the ridge crest where the Holocene deposits are thinnest (ca. $60 \mathrm{~cm}$ ), lithic artifacts were most frequent at $10-50 \mathrm{~cm}$ below the surface, while burned rocks were concentrated at $30-50 \mathrm{~cm}$ and burned clay at 30-60 cm (see Table 4.8). In Test Units 1 and 4, lithic artifacts occur throughout the ca. 100$\mathrm{cm}$-thick Holocene deposits, though they tend to be relatively infrequent in the uppermost and lowermost $10 \mathrm{~cm}$ (see Table 4.8). Both burned rocks and burned clay occur mostly in the lower half of the Holocene deposits.

The distributions in the area of the manual excavation block (Test Units 2 and 5-12), where the Holocene sands are thickest $(170 \mathrm{~cm})$ and all of the burials occurred, are more informative. The nine units excavated in the block yielded numerous temporally diagnostic artifacts and four radiocarbon dates. Figure 5.1 shows that lithic artifacts are abundant through the full thickness of the Holocene sands, with the high- est densities at $10-100 \mathrm{~cm}$ in the $\mathrm{AE}$ and $\mathrm{Bt}$ horizons and lower but still significant densities in the $2 \mathrm{Ab}$ horizon paleosol below $100 \mathrm{~cm}$. In contrast, burned rocks are common only below $70 \mathrm{~cm}$ and generally increase in density with depth, while burned clay is densest below $90 \mathrm{~cm}$, has moderate densities at 30-90 cm, and is almost nonexistent above $30 \mathrm{~cm}$.

Relating the burial features to these vertical distributions can be done best using absolute arbitrary elevations rather than depth, since most burials were identified during Gradall stripping, and thus the actual depth below surface is unknown. All four burials and Isolated Bone 2 were encountered at similar elevations, with Burial 1 at 100.43-100.55 m, Burial 2 at 100.53-100.71 m, Burial 3 at 100.42-100.62 m, Burial 4 at $100.57 \mathrm{~m}$, and Isolated Bone 2 at $100.58 \mathrm{~m}$. These elevations correlate mostly with Levels 10 and 11 and the upper part of Level 12, or the lower Bt horizon and upper $2 \mathrm{Ab}$ horizon, although the upper part of the Burial 2 pit correlates with Level 9. ${ }^{2}$ The congruence in elevations, and physical proximity, of these features suggest that they were generally contemporaneous and associated with occupation shortly after the $\mathrm{AE} / \mathrm{Bt}$ horizon surface sands began accumulating atop the $2 \mathrm{Ab}$ horizon paleosol. Isolated Bone 1 was found well below the other human remains $(100.21 \mathrm{~m})$ and thus could be earlier, but the fact that it was close to Burials 1 and 3 (within 0.7-1.0 m) and did not duplicate elements in those burials suggests that

2 In three of the nine test units, the uppermost level was subdivided into Levels $1 \mathrm{~A}$ and $1 \mathrm{~B}$ because it was greater than $10 \mathrm{~cm}$ thick; the level designations given, though, still generally represent depths below surface, e.g., Level 9 is $80-90 \mathrm{~cm}$ below surface. 


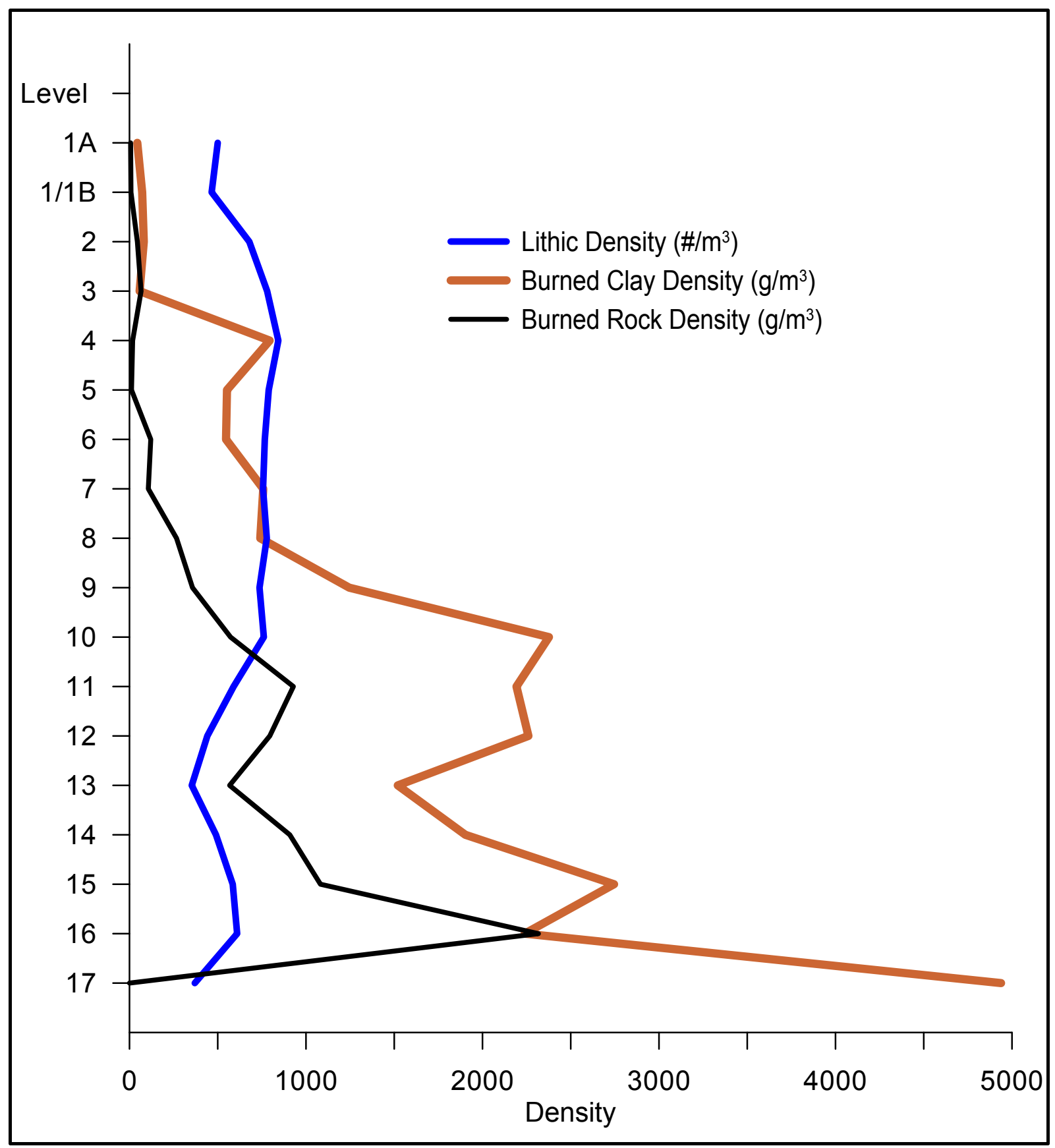

Figure 5.1. Graphs showing vertical distributions of lithic artifacts, burned rocks, and burned clay in Test Units 2 and 5-12.

it may be associated with them and have been placed downward by bioturbation.

Dating the period of occupation during which the burials occurred, or the periods that resulted in the overlying and underlying artifact deposits, remains a problem, though, with the various lines of evidence pointing to repeated reoccupation over a long span of time and much mixing. Four radiocarbon dates were obtained, three on charcoal from nonfeature contexts and one on soil humates from the $2 \mathrm{Ab}$ horizon (Table 5.1). The charcoal date from Level 15 of Test Unit 2 in the $2 \mathrm{Ab}$ horizon and humate date from 100.60-100.30 m in Backhoe 
Trench 2 are reasonably consistent and suggest that the paleosol formed toward the end of the Middle Archaic period or the early part of the Late Archaic period. This would imply that the overlying AE/Bt horizon sands accumulated after that. The other two charcoal assays are consistent with this, with one dating to the end of the Late Archaic period and the other to the early part of the Late Prehistoric period. But the fact that the younger of the two is from Level 10 and the older one is from Level 7 points to a lack of stratigraphic integrity.

Based strictly on the temporally sensitive artifacts, it could be argued that 41BU51 was occupied mostly during the Late Archaic period, with 13 dart points typed as Bulverde, Darl, Edgewood, Fort Hood Provisional Type 1, Godley, Marcos, and Pedernales. The 9 sandypaste sherds could also date to an occupation during the late part of the Late Archaic, or they could relate to subsequent Late Prehistoric occupations. Three of the 4 typed arrow points are Scallorns and an Edwards, which indicate early Late Prehistoric use; the fourth, a Fresno, is probably later, perhaps even of historic age. The other 6 certain indicators of Late Prehistoric occupation are nondiagnostic fragments and preforms. The single Meserve dart point is the oldest diagnostic artifact, implying limited use during the Paleoindian period. The other 4 typed dart points (Carrollton, Morrill, and Nolan) could relate to use during the Middle Archaic period, although Carrollton and Morrill are not well-dated types.

The vertical distributions of the 18 temporally sensitive items from Test Units 2 and 5-12 and the 22 from the surrounding Gradall excavations indicate that there is little chance of isolating the materials into discrete components, or even time periods. The materials in the upper $60 \mathrm{~cm}$ of this part of the site (above $100.96 \mathrm{~m}$ ) may date mostly to the Late Prehistoric period, with both Scallorn points, an untyped arrow point fragment, and 3 arrow point preforms coming from these deposits, although the single Edgewood and Meserve dart points and an untyped dart point fragment hint at some admixture of earlier materials.

The diagnostics from the lower part of the surface sands above the paleosol, at $60-100 \mathrm{~cm}$ or 100.96-56 m, are an amalgam of Late Archaic items (one Bulverde, two Darl, and one Godley), along with a presumably Middle Archaic Nolan point, two untyped dart points, a Late Prehistoric Fresno point and untyped arrow point fragment, and five sandy-paste sherds that could be either Late Archaic or Late Prehistoric. These are the deposits that yielded the two Late Archaic and early Late Prehistoric radiocarbon dates. Most of the burial features probably originated in the lower levels of these deposits.

The temporally sensitive artifacts from below $100 \mathrm{~cm}$, or about $100.56 \mathrm{~m}$, also are of varying ages. Most of these probably are from the $2 \mathrm{Ab}$ horizon paleosol, although some from the Gradall-excavated block may actually be from the lower part of the overlying sands, since the paleosol dipped in places. These items are mostly Late Archaic (three Bulverde, one Fort Hood Provisional Type 1, one Marcos, and three Pedernales), but three possibly Middle Archaic Carrollton and Morrill points are present, as are a Late Prehistoric Edwards point and three sandy-paste sherds that could be very Late

Table 5.1. Radiocarbon dates

\begin{tabular}{|c|c|c|c|c|c|c|}
\hline $\begin{array}{c}\text { UGA } \\
\text { Sample } \\
\text { No. }\end{array}$ & Provenience & $\begin{array}{l}\text { Measured } \\
\text { Age (B.P.) }\end{array}$ & $\begin{array}{l}{ }^{13} \mathrm{C} /{ }^{12} \mathrm{C} \\
\text { Ratio }\end{array}$ & $\begin{array}{l}\text { Corrected } \\
\text { Age (B.P.) }\end{array}$ & $\begin{array}{c}\text { 1-sigma Calibrated } \\
\text { Result (and } \\
\text { probabilities) }\end{array}$ & $\begin{array}{c}\text { 2-sigma Calibrated } \\
\text { Result (and } \\
\text { probabilities) }\end{array}$ \\
\hline 12444 & $\begin{array}{l}\text { TU 10, Level } 10 \\
(100.66-100.56 \mathrm{~m})\end{array}$ & $950 \pm 40$ & -26.7 & $920 \pm 40$ & $\begin{array}{l}\text { A.D. } 1042-1106(0.62) \\
\text { A.D. } 1117-1159(0.38)\end{array}$ & $\begin{array}{l}\text { A.D. } 1027-1191(0.97) \\
\text { A.D. } 1196-1207(0.03)\end{array}$ \\
\hline 12445 & $\begin{array}{l}\text { TU 8, Level } 7 \\
(100.96-100.86 \mathrm{~m})\end{array}$ & $1310 \pm 40$ & -26.6 & $1280 \pm 40$ & $\begin{array}{l}\text { A.D. } 677-727(0.58) \\
\text { A.D. } 737-771(0.42)\end{array}$ & $\begin{array}{l}\text { A.D. } 658-783(0.91) \\
\text { A.D. } 787-824(0.06) \\
\text { A.D. } 841-861(0.03)\end{array}$ \\
\hline 12446 & $\begin{array}{l}\text { TU 2, Level } 15 \\
(100.16-100.06 \mathrm{~m})\end{array}$ & $3820 \pm 40$ & -24.2 & $3830 \pm 40$ & $\begin{array}{l}2389-2385 \text { B.C. }(0.01) \\
2345-2202 \text { в.C. }(0.99)\end{array}$ & $\begin{array}{l}2459-2416 \text { B.C. }(0.09) \\
2411-2197 \text { B.C. }(0.87) \\
2169-2148 \text { B.C. }(0.04)\end{array}$ \\
\hline 12447 & $\begin{array}{l}\text { BHT } 2(100.60- \\
100.30 \mathrm{~m})\end{array}$ & $3650 \pm 40$ & -22.6 & $3690 \pm 40$ & $2139-2026$ в.C. $(1.00)$ & $\begin{array}{l}2198-2162 \text { в.с. }(0.09) \\
2152-1959 \text { в.с. }(0.91)\end{array}$ \\
\hline
\end{tabular}

Note: UGA-12444, 12445, and 12446 are on unidentified wood charcoal; UGA-12447 is on soil humates. 
Archaic or Late Prehistoric. The two late Middle Archaic to early Late Archaic radiocarbon dates are from these deposits.

In summary, 41BU51 has a substantial Late Archaic component that probably contributed many or even most of the lithic artifacts, the bulk of the burned rocks and burned clay, some or all of the ceramics, and probably all of the burials. Materials representing Late Prehistoric period occupations also are present, and, although diagnostic items are comparatively scarce, the possibility exists that large numbers of the lithic artifacts in the upper $60 \mathrm{~cm}$ of the deposits were left by these occupations, assuming that these remains were not churned up from the lower deposits. A small number of artifacts indicate use predating the Late Archaic period, but the contexts of these materials and the radiocarbon dates from the $2 \mathrm{Ab}$ horizon paleosol suggest these are older items recycled into younger deposits. The radiocarbon dates indicate that the Late Archaic and Late Prehistoric use of the site occurred over perhaps 3,200 to 3,600 years, and the single Fresno point could add another 600 years or so to this span. The vertical distributions of the temporally sensitive artifacts and the radiocarbon dates, while hinting at some remnant time-related stratification of the cultural materials, make it clear that there has been much mixing of the deposits, presumably through faunal turbation and other forms of disturbance. With this degree of mixing, it is impossible to segregate the remains by time period or more-discrete components. It is this characteristic, more than any other, that limits the capacity of the nonburial remains at 41BU51 to contribute important information.

\section{SITE FUNCTION}

With no ability to isolate components, it is hard to say much about the role of this site in local settlement systems. The abundance of debitage certainly points to the importance of chipped stone tool production on the site, apparently using local gravels obtained from Brazos River gravel bars. The range of tool types made seems narrow compared to sites such as 41MM340 and 41MM341 on the Little River not far away, where perforators, awls, gravers, adzes, wedges, gouges, and choppers were found (Gadus et al. 2006:108-117; Mahoney et al. 2003:48-50), but this could be a function of the more-limited sampling at 41BU51 and the lessintensive analysis of the remains recovered. The sparseness of features at 41BU51 also could be interpreted as indicating that a limited range of activities was performed there, but this may relate more to the fact that the bioturbated sands at 41BU51 are not conducive to the preservation of features.

In fact, the presence of a minimum of three human burials (and a maximum of six) in what appears to be a small terminal Late Archaic cemetery argues that, at least during that occupation, 41BU51 functioned as something more than a limited-purpose, short-term campsite. With apparently contemporaneous sites nearby such as Winnie's Mound and 41BU16 having similar kinds of remains, it appears that this stretch of the Brazos River valley, along with adjacent regions, saw increased population densities and definition of territories during the Late Archaic period. The abundance of burned clay, some of which appears to be wattle-impressed daub, in the lower deposits at the site argues that 41BU51 was used as a campsite for extended occupations during this interval. The occurrence of burned clay-which is widespread across the site-is intriguing because it seems out of place in what appears to be a Late Archaic context in this part of Texas. Assuming the burned clay chunks with stick impressions are truly daub, they imply that durable structures were erected at 41BU51.

Yet 41BU51 shows no evidence of interaction by occupants with the Caddo of east Texas. The few sherds found are a sandy paste ware unrelated to Caddo wares, and there are no Alba-Bonham or Perdiz arrow points or Gahagan knives such as those that link nearby sites like 41MM341 with the Caddo world. Of course, this may mean only that 41BU51 was not heavily used during the time when ties between the Caddo and people of the Oak Woodlands and Blackland Prairie were strongest, and it does not rule out the possibility of less-visible connections predating the Caddo period, as noted in Chapter 1.

\section{PROJECT ASSESSMENT}

This final section offers a brief synopsis of both the positive and negative aspects of this project. This is done by focusing on a few main issues. On the positive side, the excavations 
produced data from a region that is not well represented in the literature on archeological excavations in Texas: the Brazos River valley downstream from McLennan County and upstream from Austin County. In such a nearvacuum, every package of new information, even if it is not of the highest quality, can contribute to a better understanding of prehistory. In this case, the most-substantive new information relates to the nature of the Late Archaic occupation at 41BU51 and what it may be telling us about increased population densities and definition of territories.

On the negative side, the poor quality of some of the information recovered makes substantive interpretation hard. This extends from the inability to isolate components for analysis to the poor preservation and incompleteness of the skeletal remains. Also, the fact that the Burial 1 human remains were initially misidentified led to an erroneous initial evaluation of the site's eligibility for National Register listing and State Archeological Landmark designation and necessitated a second round of eligibility testing. This contributed to the overall project unfolding over an unnecessarily long period of time, which translated into increased cost. Related to the extended timeline were the protracted and ultimately unsuccessful efforts to obtain permission to perform destructive analyses (radiocarbon dating and isotopic studies) on human remains from other sites near 41BU51 held at Texas A\&M University. This turned out to be a problem, in part, because the dating and isotopic studies on the human remains from 41BU51, for which permission was obtained shortly after completion of the excavations, was delayed pending a decision on the remains from the other sites, thinking that submitting samples from all sites at once would help ensure consistency. However, by the time the decision was made about the collections at Texas A\&M University, a second round of consultation was deemed necessary. This time around objections were raised, so no dating or isotopic analyses were performed on the human remains. In retrospect, to maximize the archeological information obtainable from 41BU51, those remains should have been fully analyzed when we first had permission.

Ultimately, the lost opportunity to date the burials at 41BU51 and collect isotopic data is the most significant negative aspect of the project, especially since they will be repatriated and presumably reinterred. With this outcome, we will never truly know when those burials occurred, nor will we gain insight into the diet of the people buried there that the isotopic evidence would have provided. 



\section{GLOSSARY}

alveolar bone - the bony structure that supports the teeth.

cancellous bone - the spongy tissue that fills the interior of the bones.

cemento-enamel junction - on a tooth, the line where the cementum, which covers the roots, meets the enamel, which covers the crown.

compact bone proliferation - excess growth of the hard outer surface of a bone.

cortices (cortex) - the hard, dense outer layer of bones.

cranial hyperostosis - extensive thickening or growth of the skull.

cribra orbitalia - a porous condition in the roof of the orbit (eye socket). See porotic hyperstosis.

dentin - the calcareous tissue that constitutes the major portion of the tooth.

diaphyses - the shaft of the long bone.

diploic space - space occupied by spongy bone between inner and outer compact parts of flat cranial bones.

etiologies - causes of a disease or condition.

external auditory meatus - ear canal.

gluteal tuberosity - the ridge on the femur to which the gluteus maximus is attached.

gracility - describes slender or slight bone structure. See robusticity.

linea aspera - the ridge that runs along the posterior surface of the femur; the structure to which the muscles are attached.

linear enamel hypoplasis - an enamel deficiency visible as lines on the teeth.

nuchal crest - the ridge on the external surface of the occipital bone, which forms the back of the skull and the base of the cranium.

periosteum - the membrane of connective tissue that covers a bone and to which tissues are attached.

porotic hyperstosis - a porous condition of the cranial vault. See cribra orbitalia.

robusticity - describes strong or large bone structure. See gracility.

subperiosteal bone - the bone that lies directly under the periosteum.

supramastoid crest -the raised bone that forms the back portion of the zygomatic process.

treponemal infection - infection caused by a microorganism of the genus Treponema; includes syphilis and yaws. 



\section{REFERENCES CITED}

Acsádi, G., and J. Nemeskéri

1970 History of Human Life Span and Mortality. Akadémiai Kiadó, Budapest.

Aufderheide, Arthur C., and Conrado RodríguezMartín

1998 The Cambridge Encyclopedia of Human Paleopathology. Cambridge University Press, Cambridge.

Bement, Leland C., Wayne Bartholomew, Glenn T. Goode, Stephen A. Hall, and David G. Robinson

1989 Excavations at 41BP19, The Kennedy Bluffs Site, Bastrop County, Texas. Contract Reports in Archaeology, Report Number 5. Texas State Department of Highways and Public Transportation, Highway Design Division, Austin.

Blair, W. Frank

1950 The Biotic Provinces of Texas. The Texas Journal of Science 2(1):93-117.

Bolton, Herbert Eugene

1970 Texas in the Middle Eighteenth Century: Studies in Spanish Colonial History and Administration. The Texas State Historical Association and University of Texas Press, Austin.

Bowman, Bradley F.

1985 Winnie's Mound (41BU17): A Case Study in the Prehistory of Burleson County, Texas. Bulletin of the Texas Archeological Society 56:39-74.

1991 The Foster Site Cremation: A Single Individual, Partition Cremation in Milam County, Texas. Plains Anthropologist 36(133):31-42.

2008 Foster (41MM13): A Stratified Site near the Confluence of the Brazos and the Little Rivers: Milam County, Texas. Manuscript on file at the Museum of Archaeology and Material Culture, Cedar Crest, New Mexico.

Brown, Ken

1975 Time's Arrow and Postdepositional Disturbance. Paper presented at the 1975 Caddo Conference, College Station, Texas.

Bruseth, James E., and William A. Martin

2001 OSL Dating and Sandy Mantle Sites in East Texas. Current Archeology in Texas $3(1): 12-17$.

Bruseth, James E., and William A. Martin (editors) 1987 The Bird Point Island and Adams Ranch Sites: Methodological and Theoretical Contributions to North Central Texas Archaeology. Richland Creek Technical Series, Vol. II. Archaeology Research Program, Institute for the Study of Earth and Man, Southern Methodist University, Dallas.

Buikstra, Jane E., and Douglas H. Ubelaker (editors)

1994 Standards for Data Collection from $\mathrm{Hu}$ man Skeletal Remains. Research Series No. 44. Arkansas Archeological Survey, Fayetteville.

Bureau of Economic Geology

1974 Geologic Atlas of Texas, Austin Sheet. Bureau of Economic Geology, The University of Texas at Austin.

Campbell, T. N.

1988 Indians of Southern Texas and Northeastern Mexico: Selected Writings of Thomas Nolan Campbell. Texas Archeological Research Laboratory, with the cooperation of the Department of Anthropology, the College of Liberal Arts, and the Institute of Latin American Studies, The University of Texas at Austin. 
Carlson, David L., D. Gentry Steele, and A. G. Comuzzie

1984 Mammoth Excavations at the DuewallNewberry Site on the Brazos River in Texas, 1983. Current Research in the Pleistocene 1:63-64.

Chilton II, Earl W.

1997 Freshwater Fishes of Texas. Texas Parks and Wildlife Press, Austin.

Comuzzie, Anthony G., and D. Gentry Steele

1989 Enlarged Occlusal Surfaces on First Molars Due to Severe Attrition and Hypercementosis: Examples from Prehistoric Coastal Populations of Texas. American Journal of Physical Anthropology 78:9-15.

Copas, Wesley J.

1984 Preliminary Report on the Analysis of $\mathrm{Hu}-$ man Skeletal Remains from the Peikert Site (41WH14) in Wharton County, Texas. Houston Archeological Society Journal 79:1-7.

Davis, Michael W., Dan K. Utley, Steve A. Tomka, and Solveig A. Turpin

1987 Continuing Cultural Resource Investigations in the Calvert Prospect: The 1986 Season. Research Report No. 95. Texas Archeological Survey, The University of Texas at Austin.

Davis, William B.

1974 The Mammals of Texas. Bulletin 41. Texas Parks and Wildlife Department, Austin.

Day, D. William

1984 Archeological Mitigation at the Doyle Martin Site, 41LN178, and the P. I. Ridge Site, 41FT52, Leon and Freestone Counties, Texas. Document No. 82209. Espey, Huston and Associates, Inc., Austin.

Diamond, David D., David H. Riskind, and Steve L. Orzell

1987 A Framework for Plant Community Classification and Conservation in Texas. The Texas Journal of Science 39(3):203-221.

Ensor, H. Blaine, and Catherine S. Mueller-Wille

1988 Excavations at the Bull Pen Site, 41BP280, Colorado River Drainage, Bastrop County, Texas. Contract Reports in Archaeology, Report Number 3. Texas State Department of Highways and Public Transportation, Highway Design Division, Austin.
Fields, Ross C.

1995 The Archeology of the Post Oak Savannah of East Central Texas. Bulletin of the Texas Archeological Society 66:301-330.

Fields, Ross C. (editor)

1987 Excavations at the Alley Road Site (41LN30), Jewett Mine Project, Leon County, Texas. Reports of Investigations No. 61. Prewitt and Associates, Inc., Austin.

1990 Excavations at the Charles Cox, Lambs Creek Knoll, and Buffalo Branch Sites, Jewett Mine Project, Leon and Freestone Counties, Texas. Reports of Investigations No. 70. Prewitt and Associates, Inc., Austin.

Fields, Ross C., and L. Wayne Klement

1995 Excavations at the Cottonwood Springs Site, Jewett Mine Project, Leon County, Texas. Reports of Investigations No. 102. Prewitt and Associates, Inc., Austin.

Fields, Ross C., L. Wayne Klement, C. Britt Bousman, Steve A. Tomka, Eloise F. Gadus, and Margaret A. Howard

1991 Excavations at the Bottoms, Rena Branch, and Moccasin Springs Sites, Jewett Mine Project, Freestone and Leon Counties, Texas. Reports of Investigations No. 82. Prewitt and Associates, Inc., Austin.

Fields, Ross C., Jennifer K. McWilliams, and Karl W. Kibler

2003 Interim Report on Test Excavations at 41BU51, Burleson County, Texas. Submitted to the Texas Department of Transportation, Environmental Affairs Division, by Prewitt and Associates, Inc., Austin.

Foster, William C. (editor)

1998 The La Salle Expedition to Texas: The Journal of Henri Joutel, 1684-1687. Texas State Historical Association, Austin.

Fullem, Bruce B.

1977 The Black Hopper Site. Report No. 10. State Department of Highways and Public Transportation, Highway Design Division, Austin.

Frederick, Charles D., Mark D. Bateman, and Paul Lehman

2001 Geoarchaeological Investigations. In National Register Eligibility Testing at 41LE177, Alcoa Sandow Mine, Lee County, 
Texas: Archaeological, Geoarchaeological, and Paleoevironmental Assessment of an Upland Sandy Mantle Site, by Robert A. Ricklis, pp. 83-123. Coastal Archaeological Research, Inc., Corpus Christi.

Gadus, E. Frances, Ross C. Fields, and Karl W. Kibler

2006 Data Recovery Excavations at the J. B. White Site (41MM341), Milam County, Texas. Archeological Studies Program, Report No. 87. Environmental Affairs Division, Texas Department of Transportation, Austin. Reports of Investigations No. 145. Prewitt and Associates, Inc., Austin.

Gadus, E. Frances, Jennifer K. McWilliams, and Ross C. Fields

2002 Data Recovery Excavations at the McGuire's Garden Site (41FT425), Jewett Mine, Freestone County, Texas. Reports of Investigations No. 134. Prewitt and Associates, Inc., Austin.

Galloway, Alison

1999 Fracture Patterns and Skeletal Morphology: The Upper Extremity. In Broken Bones: Anthropological Analysis of Blunt Force Trauma, edited by Alison Galloway, pp. 113-159. Charles C. Thomas, Springfield, Illinois.

Gilmore, Kathleen Kirk

1996a San Francisco Xavier de Horcasitas Mission. In The New Handbook of Texas, Vol. 5, p. 849. The Texas State Historical Association, Austin.

1996b San Ildefonso Mission. In The New Handbook of Texas, Vol. 5, pp. 853-854. The Texas State Historical Association, Austin.

Goodman, Alan H., George J. Armelagos, and Jerome C. Rose

1980 Enamel Hypoplasias as Indicators of Stress in Three Prehistoric Populations from Illinois. Human Biology 52(3):515-528.

Hartnady, P., and Jerome C. Rose

1991 Abnormal Tooth-Loss Patterns Among Archaic-Period Inhabitants of the Lower Pecos Region, Texas. In Advances in Dental Anthropology, edited by Marc A. Kelley and Clark Spencer Larsen, pp. 267-278. Wiley-Liss, New York.
Hester, Thomas R., and Michael B. Collins

1969 Burials from the Frisch Auf! Site: 41FY2.

Texas Journal of Science 20(3):261-272.

Hillson, Simon

1996 Dental Anthropology. Cambridge University Press, Cambridge.

Howells, Robert G., Raymond W. Neck, and Harold D. Murray

1996 Freshwater Mussels of Texas. Texas Parks and Wildlife Department, Austin.

Huebner, Jeffrey A., and Anthony G. Comuzzie

1992 The Archeology and Bioarcheology of Blue Bayou: A Late Archaic and Late Prehistoric Mortuary Locality in Victoria County, Texas. Studies in Archeology 9. Texas Archeological Research Laboratory, The University of Texas at Austin.

Kalter, Ardi J., Robert M. Rogers, and Michael N. Smith

2005 Analysis and Reporting for 41FY135, the Sandbur Site, Fayette County, Texas. Document No. 020388. PBS\&J, Austin.

Kleinbach, Karl, Gemma Mehalchick, Douglas K. Boyd, and Karl W. Kibler

1999 National Register Testing of 42 Prehistoric Archeological Sites on Fort Hood, Texas: The 1996 Season. Archeological Resource Management Series, Research Report No. 38. United States Army Fort Hood, Texas.

Kotter, Steven M., Patience E. Patterson, Dan K. Utley, and Henry B. Moncure

1991 Final Report Of Cultural Resource Investigations at the Cummins Creek Mine, Fayette County, Texas. Studies in Archeology 11. Texas Archeological Research Laboratory, The University of Texas at Austin.

Kutac, Edward A.

1994 Birds. In Birds and Other Wildlife of South Central Texas, by Edward A. Kutac and S. Christopher Caran, pp. 47-102. University of Texas Press, Austin.

Lallo, J. W., George J. Armelagos, and Robert P. Mensforth

1977 The Role of Diet, Disease, and Physiology in the Origin of Porotic Hyperostosis. $\mathrm{Hu}$ man Biology 48(3):471-483. 
Langsjoen, Odin

1998 Diseases of the Dentition. In The Cambridge Encyclopedia of Human Paleopathology, by Arthur C. Aufderheide and Conrado Rodríguez-Martín, pp. 393-412. Cambridge University Press, Cambridge.

Larsen, Clark Spencer

1997 Bioarchaeology. Cambridge University Press, Cambridge.

Mahoney, Richard B., Steve A. Tomka, Raymond P. Mauldin, Harry J. Shafer, Lee C. Nordt, Russell D. Greaves, and Rebecca R. Galdeano

2003 Data Recovery Excavations at 41MM340: A Late Archaic Site Along Little River in Milam County, Texas. Archeological Studies Program Report No. 54. Environmental Affairs Division, Texas Department of Transportation, Austin. Archaeological Survey Report No. 340. Center for Archaeological Research, The University of Texas at San Antonio.

Mallouf, Michael G.

1979 Archeological Investigations at Lake Limestone. Research Report No. 71. Texas Archeological Survey, The University of Texas at Austin.

McGraw, A. Joachim, John W. Clark Jr., and Elizabeth A. Robbins

1991 A Texas Legacy, The Old San Antonio Road and the Caminos Reales, A Tricentennial History, 1691-1991. Texas Department of Transportation, Environmental Affairs Department, Austin.

McGregor, Daniel E., and James E. Bruseth (editors)

1987 Hunter-Gatherer Adaptations Along the Prairie Margin: Site Excavations and Synthesis of Prehistoric Archaeology. Richland Creek Technical Series, Vol. III. Archaeology Research Program, Institute for the Study of Earth and Man, Southern Methodist University, Dallas.

McLoughlin, Patrick

2002 Geoarcheological Survey of Sections of FM 60 from FM 50 to $\mathrm{SH} 36$, Burleson County, Texas. Letter Report No. 562. Prewitt and Associates, Inc., Austin.

McWilliams, Jennifer K., Cory Julian Broehm, and Ross C. Fields

2004 Interim Report on the Second Phase of Testing at 41BU51, Burleson County,
Texas. Submitted to the Texas Department of Transportation, Environmental Affairs Division, by Prewitt and Associates, Inc., Austin.

Meindl, Richard S., and C. Owen Lovejoy

1985 Ectocranial Suture Closure: A Revised Method for the Determination of Skeletal Age at Death Based on the Lateral-Anterior Sutures. American Journal of Physical Anthropology 68:57-66.

Natural Fibers Information Center

1987 The Climates of Texas Counties. Natural Fibers Information Center, Bureau of Business Research, The University of Texas at Austin.

Newcomb, W. W., Jr.

1993 Historic Indians of Central Texas. Bulletin of the Texas Archeological Society 64:1-63.

Ortner, Donald J.

2003 Identification of Pathological Conditions in Human Skeletal Remains, 2nd ed. Academic Press, San Diego.

Peterson, Fredrick A.

1965 The Erwin's Bridge Site at Somerville Reservoir, Burleson County, Texas. Texas Archeological Salvage Project, The University of Texas at Austin.

Ricklis, Robert A.

2001 National Register Eligibility Testing at 41LE177, Alcoa Sandow Mine, Lee County, Texas: Archaeological, Geoarchaeological, and Paleoenvironmental Assessment of an Upland Sandy Mantle Site. Coastal Archaeological Research, Inc., Corpus Christi.

Robinson, David G., and Solveig A. Turpin

1993 Hunter-Gatherer Mobility and Settlement in the Brazos Uplands: Archeology in the Calvert Mine, Robertson County, EastCentral Texas. Studies in Archeology 14. Texas Archeological Research Laboratory, The University of Texas at Austin.

Roemer, Erwin, Jr., and Shawn Bonath Carlson

1987 Excavations at 41BU16: State Highway 21 at the Brazos River, Burleson County, Texas. Contract Reports in Archaeology, Report Number 1. Texas State Department of Highways and Public Transportation, Highway Design Division, Austin. 
Rogers, Robert

1993 Data Recovery of Three Prehistoric Sites at the Gibbons Creek Third Five-Year Mine Permit Area, Grimes County, Texas. Document No. 910529. Espey, Huston and Associates, Inc., Austin.

1994 Excavations at Site 41GM224 in Gibbons Creek Lignite Mine Permit 38A Area, Grimes County, Texas. Document No. 930476. Espey, Huston and Associates, Inc., Austin.

1995 Excavations at Sites 41GM166, 41GM281 and 41GM282 at the Gibbons Creek Lignite Mine, Grimes County, Texas. Document No. 940611. Espey, Huston and Associates, Inc., Austin.

1997 National Register Testing at Site 41LE120, Lee County, Texas. Document No. 970348. Espey, Huston and Associates, Inc., Austin.

1999 Excavations at the Walleye Creek Site (41LE57), Lee County, Texas. Document No. 981670. Espey, Huston and Associates, Inc., Austin.

Rogers, Robert, and Steve Kotter

1995 Archaeological Investigations at the Chesser Site (41LE59), Lee County, Texas. Document No. 950209. Espey, Huston and Associates, Inc., Austin.

Rose, Jerome C., Keith W. Condon, and Alan H. Goodman

1985 Diet and Dentition: Developmental Disturbances. In The Analysis of Prehistoric Diets, edited by R. I. Gilbert Jr. and J. H. Mielke, pp. 281-305. Academic Press, London.

Scott, E. C.

1979 Dental Wear Scoring Technique. American Journal of Physical Anthropology 51:213-217.

Scott, G. Richard, and Christy G. Turner

1997 The Anthropology of Modern Human Teeth. Cambridge University Press, Cambridge.

Shafer, Harry J.

1973 Lithic Technology at the George C. Davis Site Cherokee County, Texas. Ph.D. dissertation, Department of Anthropology, The University of Texas at Austin.
2006 People of the Prairie: A Possible Connection to the Davis Site Caddo. Environmental Affairs Division, Texas Department of Transportation, Austin. Prewitt and Associates, Inc., Austin. Electronic document, http://www.counciloftexasarcheologists.org/publications/PrairieCaddo Module.pdf.

Skelton, Duford W.

1977 Archeological Investigations at the Fayette Power Project, Fayette County, Texas. Research Report No. 60. Texas Archeological Survey, The University of Texas at Austin.

Smith, B. Holly

1984 Patterns of Molar Wear in Hunter-Gatherers and Agriculturalists. American Journal of Physical Anthropology 63:39-56.

Sobolik, Kristin D.

1991 Prehistoric Diet and Subsistence in the Lower Pecos as Reflected in Coprolites from Baker Cave, Val Verde County, Texas. Studies in Archeology 7. Texas Archeological Research Laboratory, The University of Texas at Austin.

Spouge, J. D.

1973 Oral Pathology. C. V. Mosby, St. Louis.

Steele, D. Gentry

1987 Human Skeletal Remains Recovered from 41BU16. In Excavations at 41BU16: State Highway 21 at the Brazos River, Burleson County, Texas, by Erwin Roemer Jr. and Shawn Bonath Carlson, pp. 197-212. Contract Reports in Archaeology, Report Number 1. Texas State Department of Highways and Public Transportation, Highway Design Division, Austin.

Story, Dee Ann

1972 A Preliminary Report of the 1968, 1969 and 1970 Excavations at the George C. Davis Site, Cherokee County, Texas. The University of Texas at Austin.

Stuart-Macadam, Patty

1987 Porotic Hyperostosis: New Evidence to Support the Anemia Theory. American Journal of Physical Anthropology 74:521526.

1989 Porotic Hyperostosis: Relationship Between Orbital and Vault Lesions. American Journal of Physical Anthropology 80:187-193. 
1992 Porotic Hyperostosis: A New Perspective. American Journal of Physical Anthropology 87:39-47.

Thoms, Alston V. (editor)

1993 The Brazos Valley Slopes Archaeological Project: Cultural Resources Assessments for the Texas A\&M University Animal Science Teaching and Research Complex, Brazos County, Texas. Reports of Investigations No. 14. Archaeological Research Laboratory, Texas A\&M University, College Station.

Thoms, Alston V., and Steven W. Ahr

1996 Archaeological Studies at Birch Creek Unit and Yegua Creek Fishing-Access Area, Lake Somerville State Park, Burleson County,
Texas, Interim Report, September 1996. Center for Environmental Archaeology, Texas A\&M University, College Station.

Turner, Christy G., II, Christian R. Nichol, and G. Richard Scott

1991 Scoring Procedures for Key Morphological Traits of the Permanent Dentition: The Arizona State University Dental Anthropology System. In Advances in Dental Anthropology, edited by Marc A. Kelley and Clark Spencer Larsen, pp. 13-31. Wiley-Liss, New York.

Wood, James W., George R. Milner, Henry C. Harpending, and Kenneth M. Weiss

1992 The Osteological Paradox. Current Anthropology 33:343-370. 
APPENDIX A: Selected Backhoe Trench Profiles 


\section{Trench 1, South Wall}

AE horizon: $\quad$ 0-28 cm, brown (10YR 5/3) fine sand, very friable, weak medium blocky subangular structure, few distinct coarse (10YR 4/2) mottles, common krotovinas, clear smooth to wavy lower boundary. Late Holocene colluvium and slopewash.

B horizon: $\quad 28-67 \mathrm{~cm}$, dark grayish brown (10YR 4/2) loamy fine sand, very friable, weak medium blocky subangular structure, common distinct coarse (10YR 5/3) mottles, common krotovinas, few clay lamellae ( $<5 \mathrm{~mm}$ thick), abrupt smooth lower boundary. Late Holocene colluvium and slopewash.

2Ab horizon: $\quad 67-86 \mathrm{~cm}$, very dark grayish brown (10YR 3/2) sandy clay loam, friable, moderate fine blocky angular structure, few prominent fine (7.5YR 4/4) mottles, common krotovinas, few pieces of charcoal, few burned rocks, clear smooth lower boundary. Heavily bioturbated paleosol observed across trench profile, although its thickness and state of preservation vary. Holocene colluvium and slopewash.

2Btb horizon: $86-90+\mathrm{cm}$, yellowish red (5YR 4/6) sandy clay, firm, moderate medium prismatic structure, few prominent fine (10YR 3/2) mottles, common krotovinas, lower boundary not observed. Truncated soil imprint on Eocene-age bedrock.

\section{Trench 2 (Test Unit 2), South Wall}

AE horizon: $\quad$ 0-36 cm, brown (10YR 4/3) fine sand, very friable, weak fine blocky subangular structure, weak distinct coarse (10YR 4/2) mottles, common krotovinas, gradual wavy lower boundary. Late Holocene colluvium and slopewash.

Bt horizon: $\quad 36-110 \mathrm{~cm}$, dark grayish brown (10YR 4/2) loamy fine sand, very friable, weak fine blocky subangular structure, common distinct coarse (10YR 4/3) mottles, common krotovinas, common clay lamellae (5 mm thick, 10YR 2/2), abrupt wavy lower boundary. Late Holocene colluvium and slopewash.

2Ab horizon: $\quad 110-170 \mathrm{~cm}$, very dark gray (10YR 3/1) sandy clay, friable, moderate medium blocky subangular structure, few prominent coarse (7.5YR 4/4 to 5/4) mottles, common krotovinas, few pieces of charcoal, abrupt smooth lower boundary. This paleosol becomes thinner to the west, where it is eroded to the point where it is no longer observable in the profile. At the east end of the trench profile, the soil is very prominent and ca. 50-60 cm thick. Holocene (late?) colluvium and slopewash. 
2Btb horizon: $170-200+\mathrm{cm}$, interbedded brown (7.5YR 4/4 to 5/4) sandy clay and yellowish brown (10YR 6/6) medium to coarse sand, friable, moderate medium blocky angular structure, common thick sand beds, some with 10-20-mm-thick clay lamellae (10YR 2/2), common faint to distinct coarse (10YR 4/3) mottles, sandy (7.5YR 5/4 and 10YR 6/6) mottles, lower boundary not observed. Truncated soil imprint on Eocene-age bedrock.

\section{Trench 3 (Test Unit 3), North Wall}

AE horizon: $\quad$ 0-30 cm, dark brown (10YR 3/3) fine sand, very friable, weak fine blocky subangular structure, common distinct coarse (10YR 3/2) mottles, common krotovinas, clear wavy lower boundary. Late Holocene colluvium and slopewash.

B horizon: $\quad 30-58 \mathrm{~cm}$, very dark grayish brown (10YR 3/2) loamy fine sand, very friable, weak fine blocky subangular structure, few distinct coarse (10YR 3/3) mottles, common krotovinas, clear wavy lower boundary. Late Holocene colluvium and slopewash.

2Btb horizon: $58-71+\mathrm{cm}$, strong brown ( 7.5 YR 5/6 to 5/8) sandy clay loam, firm, moderate medium blocky angular structure, few prominent medium (5YR 4/6) mottles, many distinct coarse (10YR 4/3) mottles, common Fe-Mn concretions and nodules, common krotovinas, lower boundary not observed. Truncated soil imprint on Eocene-age bedrock. 

APPENDIX B: Skeletal Diagrams Showing Sided Elements Represented in Burials 1-4 
Testing and Data Recovery Excavations at 41BU51

ADULT SKELETON RECORDING FORM: ANTERIOR VIEW

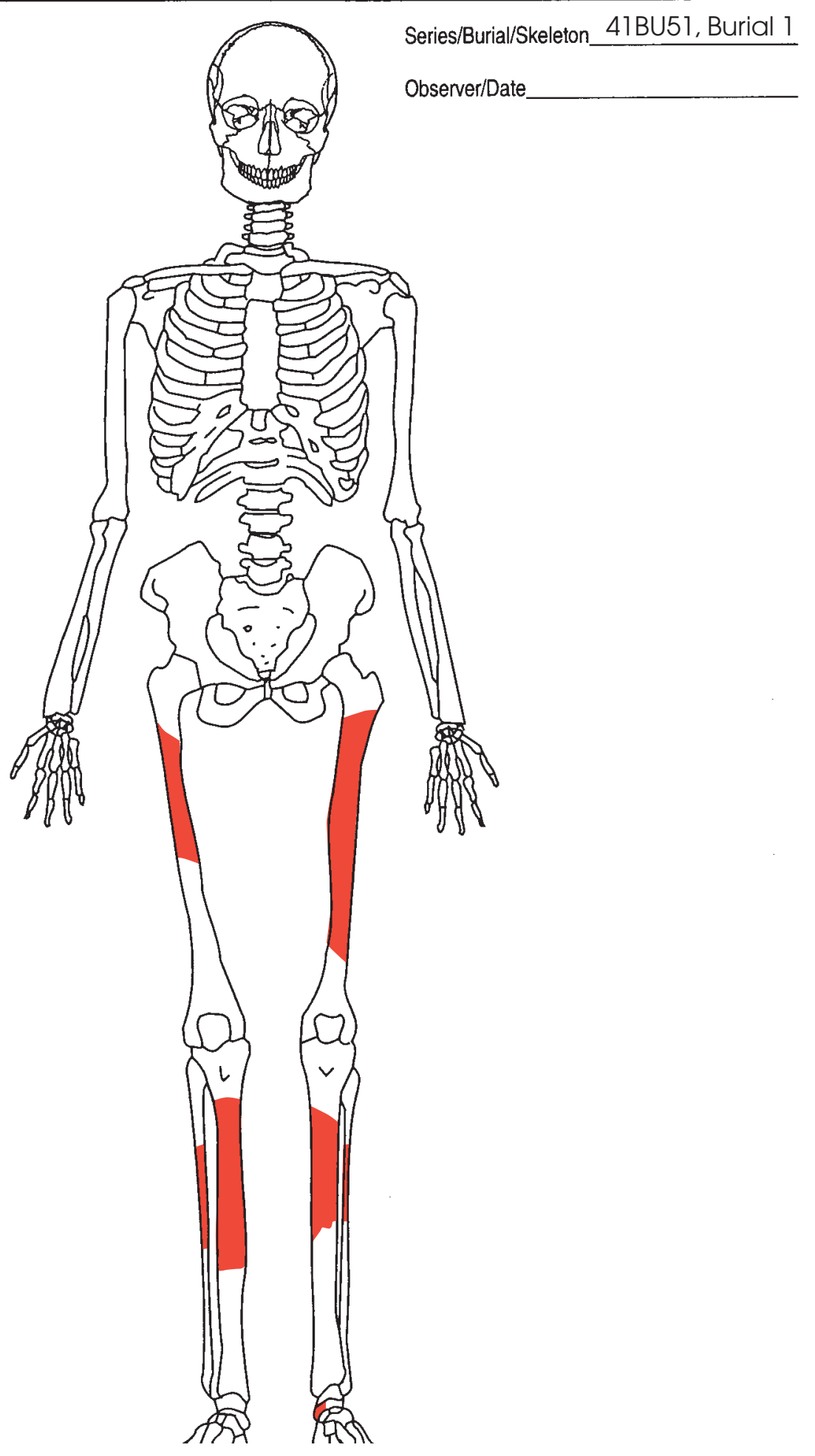




\section{ADULT SKELETON RECORDING FORM: POSTERIOR VIEW}

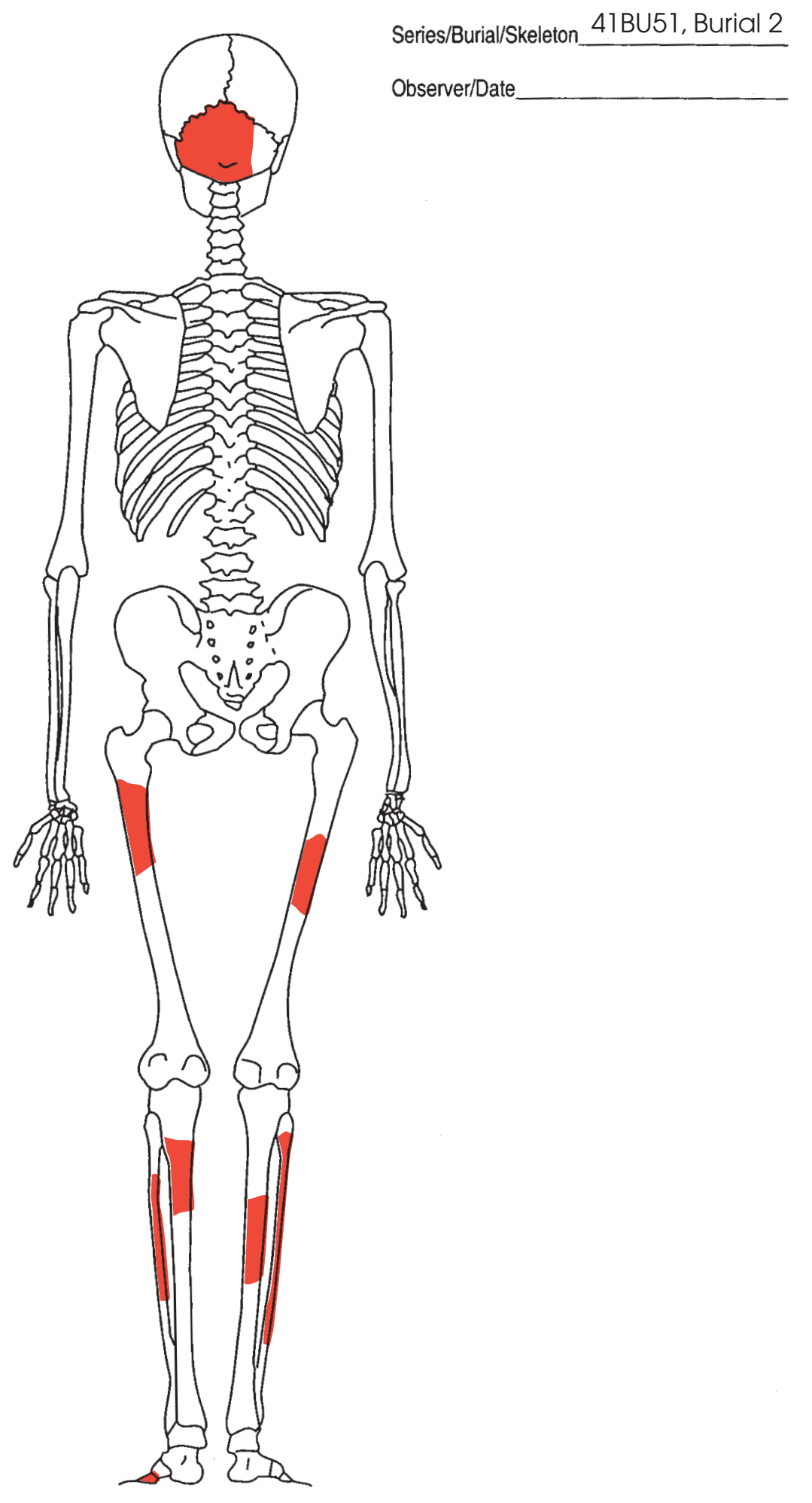


Testing and Data Recovery Excavations at 41BU51

\section{ADULT SKELETON RECORDING FORM: RIGHT LATERAL VIEW}

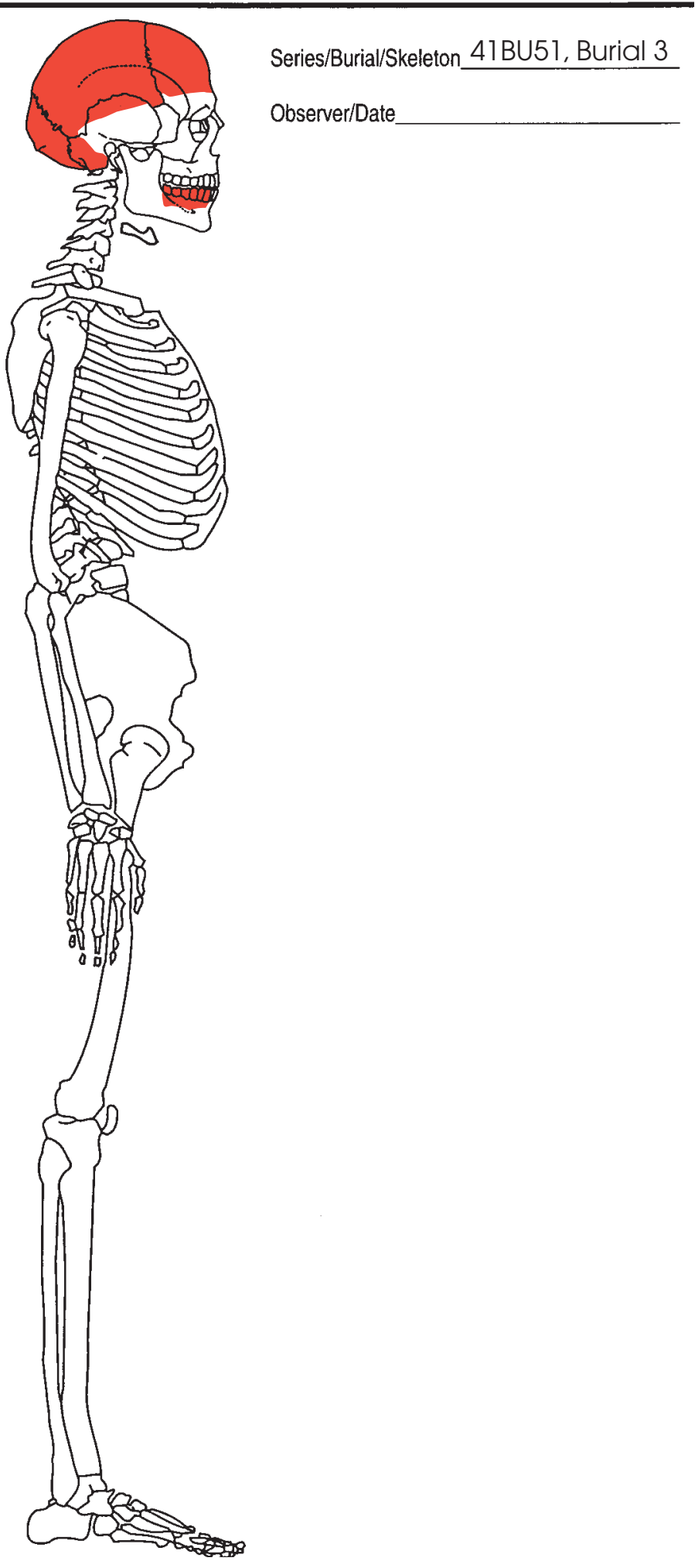




\section{ADULT SKELETON RECORDING FORM: LEFT LATERAL VIEW}

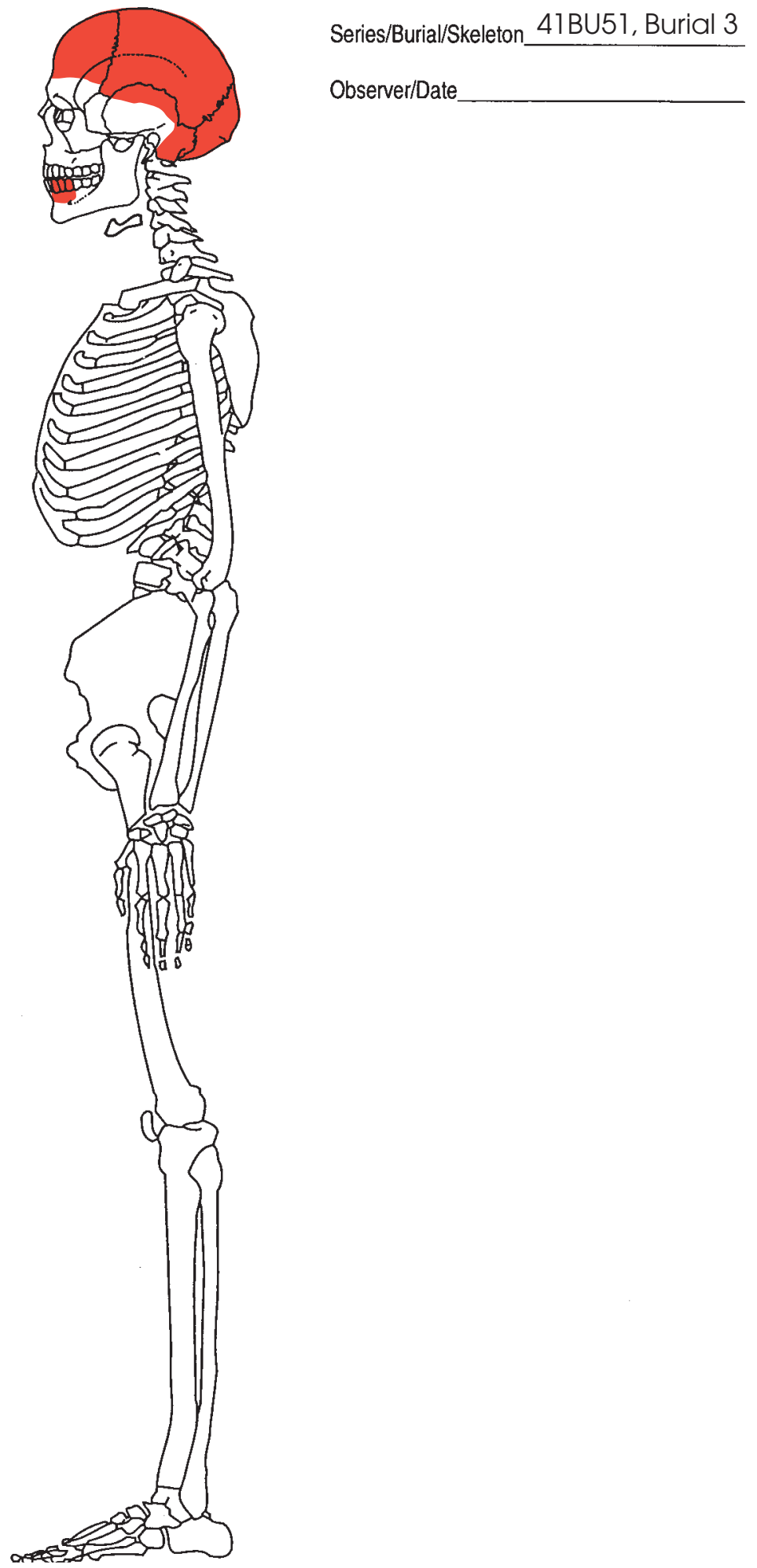


Testing and Data Recovery Excavations at 41BU51

\section{ADULT SKELETON RECORDING FORM: POSTERIOR VIEW}

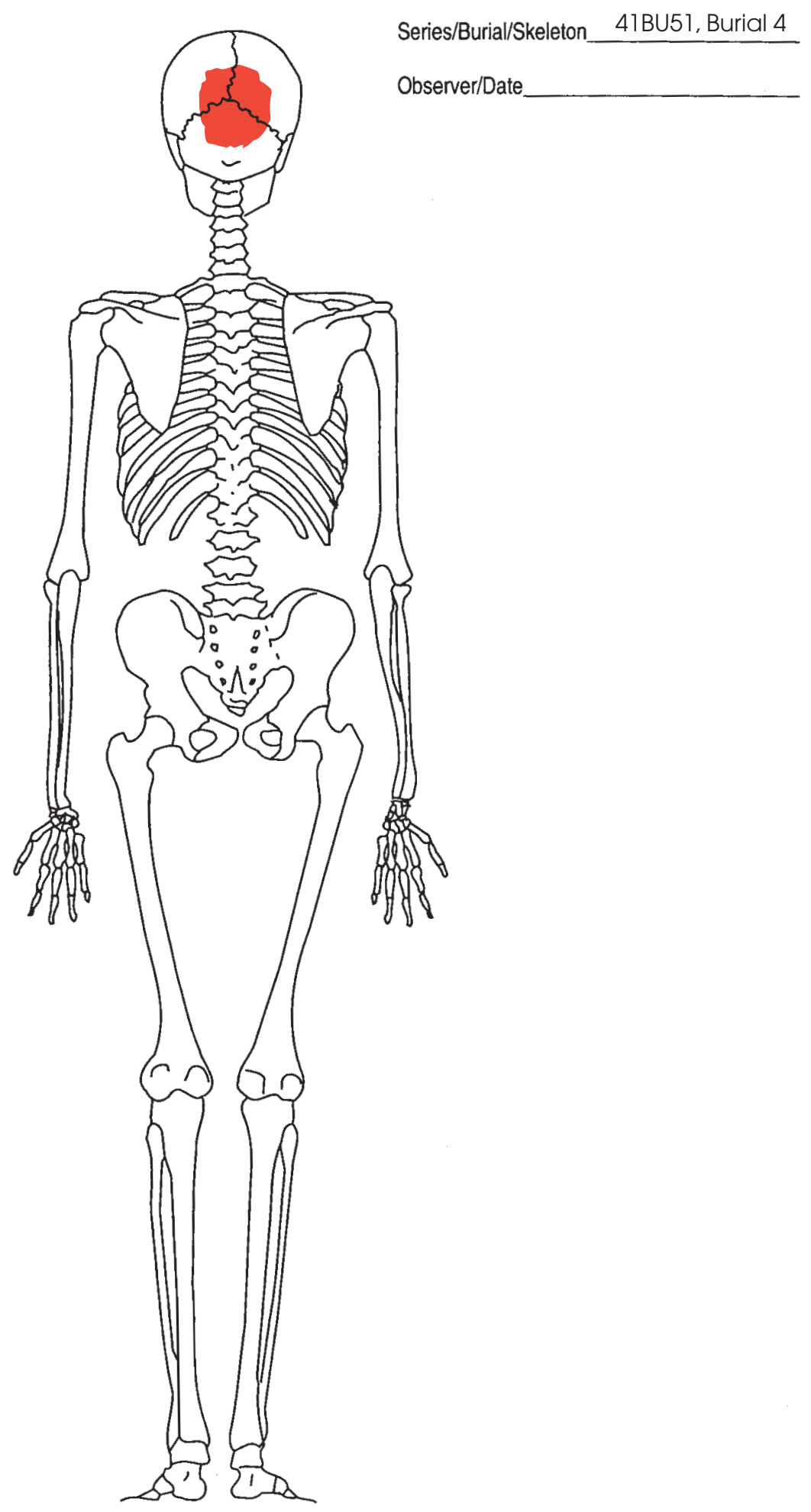

